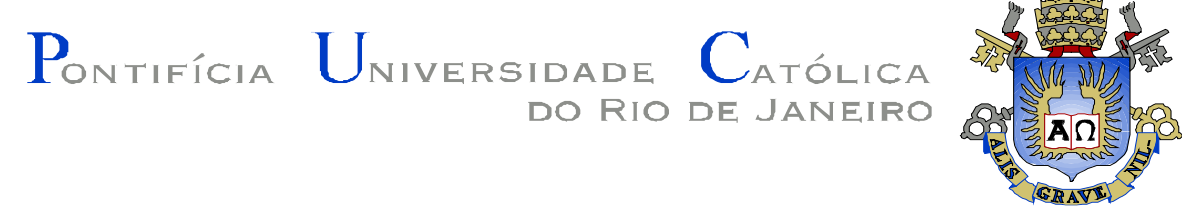

Carlos Mendes Rosa

\title{
Envelhecer em tempos de juventude: corpo, imagem e temporalidade
}

Tese apresentada ao Programa de Pós-graduação em Psicologia da PUC-Rio como requisito parcial para obtenção do título de Doutor em Psicologia Clínica.

Orientadora: Prof ${ }^{a}$. Junia de Vilhena 


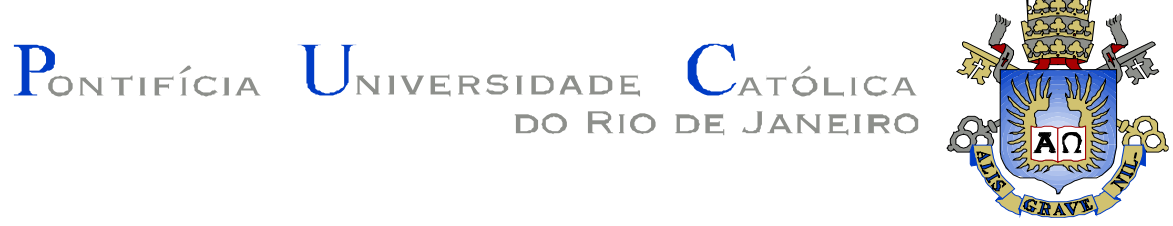

Carlos Mendes Rosa

\section{Envelhecer em tempos de juventude: corpo, imagem e temporalidade}

Tese apresentada como requisito parcial para obtenção do grau de Doutor pelo Programa de Pós-Graduação em Psicologia (Psicologia Clínica) do Departamento de Psicologia do Centro de Teologia e Ciências Humanas da PUC-Rio. Aprovada pela Comissão Examinadora abaixo assinada.

Profa. Junia de Vilhena

Orientadora

Departamento de Psicologia - PUC-Rio

Profa. Maria Inês Garcia de Freitas Bittencourt

Departamento de Psicologia - PUC-Rio

Profa. Monah Winograd

Departamento de Psicologia - PUC-Rio

Profa. Ana Maria de Toledo Piza Rudge

Departamento de Psicologia - PUC-Rio

Profa. Joana de Novaes Vilhena Universidade Veiga de Almeida - UVA

Profa. Denise Berruezo Portinari Coordenadora Setorial de Pós-Graduação

e Pesquisa do Centro de Teologia e Ciências Humanas - PUC-Rio

Rio de Janeiro, 28 de abril de 2015. 
Todos os direitos reservados. É proibida a reprodução total ou parcial do trabalho sem autorização da universidade, do autor e da orientadora.

\section{Carlos Mendes Rosa}

Mestre em Psicologia Clínica pela PUC-Rio. Graduou-se em Psicologia pela PUC-Goiás. Fez Especialização em Psicopatologia Clínica pela UNIP. Pesquisador Associado do Laboratório Interdisciplinar de Pesquisa e Intervenção Social - LIPIS da PUC - Rio. Bolsista da CAPES.

Ficha Catalográfica

Rosa, Carlos Mendes

Envelhecer em tempos de juventude: corpo, imagem e temporalidade / Carlos Mendes Rosa ; orientadora: Junia de Vilhena. - 2015.

$153 \mathrm{f}$. : il. ; $30 \mathrm{~cm}$

Tese (doutorado)-Pontifícia Universidade Católica do Rio de Janeiro, Departamento de Psicologia, 2015.

Inclui bibliografia

1. Psicologia - Teses. 2. Envelhecimento. 3. Corpo. 4. Subjetividade. 5. Psicanálise. I. Vilhena, Junia de. II. Pontifícia Universidade Católica do Rio de Janeiro. Departamento de Psicologia. III. Título. 


\section{Agradecimentos}

À minha Orientadora Junia de Vilhena, por ter sido muito mais que orientadora, muito mais que amiga para mim e para a Aline, muito mais que avó para o Ian. Pela enorme participação em todas as minhas conquistas, serei eternamente grato.

Ao meu co-orientador em Portugal, professor Eduardo Santos, pela acolhida em Coimbra e pelas conversas sempre instigantes.

À CAPES e à PUC-Rio, pelos auxílios concedidos, sem os quais este trabalho não poderia ter sido realizado.

Aos professores e funcionários do Departamento de Psicologia da PUC-Rio que me orientaram e com os quais tive o prazer de aprender muito ao longo desses anos.

Às professoras Maria Helena Zamora e Maria Inês Bittencourt cujos trabalhos foram e continuam sendo uma fonte de inspiração para meus estudos e publicações.

Aos colegas do Laboratório Interdisciplinar de Pesquisa e Intervenção Social (LIPIS) da PUC-Rio e do Instituto de Psicologia Cognitiva da Universidade de Coimbra com os quais pude trocar conhecimentos e experiências muito valiosos.

A Joana Novaes, Alysson Assunção, Ricardo Pocinho e todos os demais co-autores dos artigos que integram essa Tese de Doutorado, meu agradecimento pela oportunidade de trabalharmos juntos nesses projetos e por tudo que me ensinaram.

Aos professores e alunos do IBMR Centro Universitário pelos momentos singulares de compartilhamento de conhecimentos e vivências nas aulas, supervisões e conversas de corredor. Eu aprendi muito com cada um de vocês.

A Lana Veras, pela cumplicidade nas letras e por tudo que já escrevemos até hoje.

Aos meus familiares que sempre me apoiaram e torceram pelo meu sucesso. 
Ao Rafael e à Jackeline por estarem sempre por perto. Somos nós que devemos muito a vocês.

A Aline, pelo seu companheirismo, amor, confiança, alegria e carinho. Por enfrentar o calor, o frio e as adversidades sempre com um otimismo contagiante.

Ao Ian, que me ensinou que eu tenho uma capacidade de amar muito maior do que eu poderia imaginar.

E a todos os idosos com os quais tive o prazer de conviver nesses anos, aprendendo sempre coisas incríveis. Especialmente, meu avô Olavo de quem pude beber o vinho envelhecido e saboroso de sua sabedoria e suas experiências de vida. Não conheço palavras suficientes para expressar minha gratidão. 


\section{Resumo}

Rosa, Carlos Mendes; Vilhena, Junia. Envelhecer em tempos de juventude: corpo, imagem e temporalidade. Rio de Janeiro, 2015. 153p. Tese de Doutorado - Departamento de Psicologia, Pontifícia Universidade Católica do Rio de Janeiro.

Este trabalho é uma reunião de artigos científicos - publicados, aceitos ou submetidos a periódicos indexados - sobre as particularidades do envelhecimento em homens e mulheres no atual contexto de nossa sociedade. Os artigos analisam as diferentes nuances da subjetividade dos idosos, enfocando questões como o desencontro entre o inconsciente atemporal e o corpo envelhecido, bem como os estereótipos e os rótulos que o imaginário social cria acerca do envelhecimento. Destaque é dado ao silenciamento e ao distanciamento em relação à velhice, especialmente no que toca aos temas da decrepitude, da morte e do trabalho de elaboração psíquica necessário para enfrentar essa última fase da vida.

\section{Palavras-chave}

Envelhecimento; corpo; subjetividade; psicanálise. 


\section{Abstract}

Rosa, Carlos Mendes; Vilhena, Junia (Advisor). Aging in times of youth: body image and temporality. Rio de Janeiro, 2015. 153p. Doctoral Thesis Departamento de Psicologia, Pontifícia Universidade Católica do Rio de Janeiro.

This study is a collection of scientific papers - published, accepted or submitted to certified publications - on the particularities of the aging process in men and women in the current context of our society. The articles examine the different nuances of the subjectivity of the elderly, focusing on issues such as the disparity between the ageless unconsciousness and the aging body, as well as the stereotypes and labels that social consciousness creates concerning aging. The papers highlight the silencing and distancing of society from old age, especially from topics such as the decay of the body, the imminence of death and the psychic elaboration needed to face this last stage of life.

\section{Keywords}

Aging; body; subjectivity; psychoanalysis 


\section{Sumário}

1. Introdução

2.Primeiro Artigo: Silêncio, exclusão e morte. O trabalho do negativo na velhice?

3. Ensaio: A sombra de um corpo que se anuncia: corpo, imagem e envelhecimento

4. Segundo Artigo: Envelhecimento e seus possíveis destinos.

Uma reflexão acerca do trabalho do negativo

5. Terceiro Artigo: Reflexos do tempo: uma reflexão sobre o envelhecimento nos dias de hoje

6. Quarto Artigo: Eternamente jovens? Beleza e

7. Conclusão

8. Referências bibliográficas

9. Anexos 


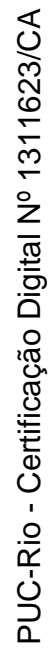

"É com adolescentes que duram um número bastante grande de anos que a vida faz velhos" Proust 


\section{Introdução}

Primeiramente, gostaria de dizer que minha opção foi fazer essa tese de doutorado em artigos. Todos os artigos aqui apresentados, apesar de independentes entre si, trazem como temática central o envelhecimento, e como pano de fundo a vivência das subjetividades no corpo. São artigos de autoria pessoal, ou escritos em parceria com minha orientadora e/ou com colegas que também se interessam e pesquisam sobre a velhice e temas correlatos. Todos confeccionados e submetidos ao longo de meu percurso como doutorando da PUC-Rio.

A escolha pela apresentação dos artigos se dá na tentativa de abarcar diferentes aspectos do complexo fenômeno do envelhecer, tanto para homens quanto para mulheres. Mas, é também um tributo a prática interdisciplinar de pesquisa, uma das particularidades da Linha de Pesquisa "Psicanálise, clínica e cultura", a qual estou vinculado, no Programa de Pós-Graduação em Psicologia Clínica da PUC-Rio, cujos frutos, para além dos textos aqui selecionados, contribuem para uma forma de fazer ciência que ultrapassa os limites da universidade e convida ao diálogo e a participação em projetos e intervenções.

Muitas razões me levaram a escrever sobre corpo e envelhecimento. Algumas delas pessoais, como a estreita relação de carinho com meus avós paternos. Outras razões acadêmicas, como a minha vinculação ao Laboratório Interdisciplinar de Pesquisa e Intervenção Social (LIPIS) da PUC-Rio, que possui um núcleo específico que estuda as questões do corpo e do envelhecimento (ENVELHECENTRO), e que, abordando-os em sua dimensão psíquica e social, realiza atendimentos a pacientes e suas famílias e atua nas comunidades e nos serviços públicos de saúde, objetivando melhorar os cuidados básicos despendidos aos idosos e a criação de políticas públicas que minimizem seu desamparo.

Motivações sociais dado o contexto demográfico atual, em que verificamos um acréscimo de anos à vida, e no qual torna-se imperioso acrescentar também vida aos anos que se alongam, como forma de possibilitar aos velhos uma última etapa existencial saudável e enriquecida por um mínimo de autonomia e independência (Saunders apud Araujo e Silva, 2007). 
Também poderia advogar que esta pesquisa se insere em um momento atual de interesse crescente em relação ao fenômeno do envelhecimento por parte da comunidade científica. Tal fato pode ser constatado através de um número cada vez maior de publicações acadêmicas que abordam o tema, bem como uma maior frequência de eventos e periódicos científicos na área das ciências humanas e da saúde.

O fato curioso é que, independente das minhas motivações, as pessoas costumam ter uma reação de estranhamento quando digo que estou pesquisando sobre a velhice. Algumas vezes a incredulidade se apresenta sob a forma da pergunta “mas você é tão jovem e está estudando isso?”. Em outras ocasiões aparece uma certa admiração por um “jovem” estar se preocupando com os "velhos". De uma maneira ou de outra, se interessar pelo envelhecimento parece causar estranheza. Entra no campo do interdito, daquelas coisas sobre as quais é melhor não dizer, muito menos pesquisar sobre.

Não consigo pensar em outra comparação que não a do Unheimlich freudiano, aquela coisa tão estranha aos nossos olhos que chega a ser familiar. É claro, que tanto no caso dos exemplos de Freud quanto no da relação com a velhice, a estranheza é apenas suposta, pois o algo visto é sim bastante familiar. Algo que carregamos dentro de nós, mais ou menos adormecido, mas sempre pronto a eclodir. Daí vem a estranheza, do fato de o vermos do lado de fora da nossa caixa de pandora.

Uma fábula do escritor Augusto Monteroso, publicada ainda em 1969, no México, e traduzida para o Brasil por Millôr Fernandes, cujo título é "Origem dos anciãos", ilustra de forma curiosa a não familiaridade com o fenômeno do envelhecimento.

Um menino de cinco anos explicava outra tarde a um de quatro que entre muitos deles se conserva a mais rigorosa pureza sexual e nem sequer se tocam entre si porque sabem - ou pensam saber - que, se por acaso se descuidam e se deixam arrastar pela paixão própria da idade e copulam, o fruto inevitável dessa união contra a natureza é inexoravelmente um velhinho ou uma velhinha; que dessa maneira se diz que nasceram e nascem todos os dias os anciãos que vemos nas ruas e nos parques; e que talvez essa crença derive de que os meninos nunca veem jovens os seus avós 
e de que ninguém lhes explique de onde vêm; mas que na realidade a sua origem não é necessariamente essa (Monterroso, 2014, p. 83).

Mas é no cotidiano que encontramos exemplo paradigmático desse estranhamento em relação à velhice, especialmente no campo da sexualidade. O primeiro capítulo da novela global "Babilônia”, escrita por Gilberto Braga, Ricardo Linhares e João Ximenes Braga, que estreou em 16 de março de 2015, causou a revolta de vários seguimentos que dizem representar "a família brasileira" por conta de uma cena em que as atrizes Fernanda Montenegro e Nathalia Timberg se beijam na boca. Segundo esses defensores da família, trata-se de um péssimo exemplo para as crianças, de uma cena desnecessária na televisão, ameaça aos valores da família, ou mesmo de prática herética. É claro que houve também muita gente que aplaudiu entusiasticamente.

A meu ver, duas coisas suscitam reflexão. A imensa repercussão (positiva ou negativa) de algo que deveria ser natural entre casais, exatamente por tratar-se da junção de dois grupos estereotipados e vistos como diferentes (velhos e homossexuais) encarnados nas personagens. Como se relações homo afetivas não existissem em todos os grupos etários da população. No entanto, nos ataques às personagens Estela e Teresa se manifesta mais um preconceito, agora contra a sexualidade dos idosos no âmbito social, sobre a qual ainda pesa um silêncio constrangido. Mais que a decadência das formas é o olhar dos outros, condenatório, que proíbe aos corpos envelhecidos, sujeitos à impiedosa escultura do tempo, o alumbramento diante da vida (Oliveira, 2015). Porque como bem disse Leonardo Sakamoto se fossem duas mulheres jovens, tudo bem, pois faz parte do fetiche masculino. Mas duas senhoras de 85 anos, com idade para serem avós, não (Sakamoto, 2015).

Mas, principalmente, chama a atenção a utilização das palavras "mau exemplo" e "exposição desnecessária" para designar a cena, quando todo o restante do capítulo da novela foi um cabedal de práticas condenáveis pela moral vigente. Ali desfilaram duas cenas de traição, mentiras, discussão familiar, tramas de vingança e até assassinato. No entanto, mais uma vez, o incômodo e a estranheza recaíram sobre a cena banal de duas mulheres velhas expressando o seu afeto. 
No momento em que a velhice ganha novos campos de circulação nas diferentes esferas sociais, tais como o mercado com suas ofertas de produtos e serviços específicos para este público, o estado de direito com leis e estatutos, a ciência através da geriatria e da gerontologia, ainda parece existir uma cegueira por parte da maioria da população, quando o assunto são os velhos e suas singularidades. Então, vamos abrir essa caixa de pandora e pensar sobre a espinhosa temática do envelhecimento, seus estereótipos, rótulos, suas facetas e dramas vividos no contexto atual de nossa sociedade. Podemos!? Devemos!?

Talvez a definição mais aceita de velhice seja aquela dada por Simone de Beauvoir, em seu livro "A velhice", que a entende "como um fenômeno biológico com reflexos profundos na psique do homem". Esta etapa da vida se mostra pelas atitudes típicas da idade, a qual não pode ser qualificada como jovem ou adulta, mas sim a "idade avançada" (Beauvoir, 1990, p.15). Nesse sentido a velhice deve ser compreendida em sua totalidade; não apenas na sua vertente biológica, mas também cultural. Exatamente por ter uma dimensão existencial, que modifica a relação da pessoa com o tempo, o mundo e com sua própria história (Freitas et al, 2010).

Na nossa contemporaneidade as transformações ocorridas no âmbito social, político, ético e estético inscrevem afirmativamente a velhice nas relações com o mundo e forjam novas modalidades de subjetivação (Birman, 2013). No entanto, é necessário levar em consideração a irreversibilidade do envelhecimento biológico, vinculado a finitude da vida, acarretando a lentidão dos movimentos físicos, a perda de memória, a diminuição da capacidade orgânica de recuperação celular e tantos outros fatores que levaram a sociedade a, verificando tais diferenças, propor uma separação social dos indivíduos (Vilhena, Rosa e Novaes, 2013).

Outro fato que chama a atenção é que o envelhecimento costuma aparecer mais claramente para os outros do que para o próprio sujeito; ele é um novo estado de equilíbrio biológico: se a adaptação às novas condições de vida se opera sem choques (doenças crônicas, graves acidentes etc), o indivíduo que envelhece costuma ter uma sensação de continuidade do seu status quo (Vilhena, Rosa e Novaes, 2014).

Há que se reconhecer que o envelhecimento possui certas limitações, as quais vão se agravando com o passar do tempo, mas tem também potencialidades 
únicas e distintas, tais como a serenidade, a experiência adquirida e a perspectiva de vida pessoal e social. Portanto, a velhice deve ser considerada como uma fase de desenvolvimento humano e não mais através da perspectiva simplista que a coloca, exclusivamente, como um período de perdas e incapacidades. Mais do que isso, o envelhecimento ganha o estatuto de um processo de vida, marcado por mudanças biopsicossociais específicas. Estas mudanças podem ser observadas em vários ciclos vitais (infância, adolescência) e são de origem biológica (avaliada pelas capacidades funcionais e pelo limite de vida dos seres orgânicos que perdem a sua capacidade de adaptação e de autorregulação com o passar dos anos, isto é, resulta de uma vulnerabilidade crescente), psicológica (capacidades comportamentais da pessoa para se adaptar ao meio envolvente) e social (papéis e hábitos desenvolvimentos pelo indivíduo na sociedade) (Vieira, 1996). O caráter biopsicosocial permite perceber que o envelhecimento é complexo, dinâmico e idiossincrático, daí os indivíduos não envelhecerem todos da mesma forma.

Por estas razões, optei por assumir essa perspectiva da velhice como um processo, que pode ser estudado sob vários ângulos, mas que agrega também muitos preconceitos associados ao que representa. Estas diferentes modalidades de preconceito se expressam em várias atitudes do cotidiano como a exclusão social, o apagamento subjetivo, o desinteresse pela história de vida e o medo do contato com a velhice, devido a sua estreita vinculação com a figura da morte.

Em meu primeiro esboço acerca da velhice, intitulado "Silêncio, exclusão e morte: o trabalho do negativo na velhice", publicado na Revista Polêm!ca, abordei de maneira sucinta estes temas, os quais foram melhor aprofundados em um ensaio aqui apresentado. Ainda que o mesmo não esteja sendo avaliado para o exame desta tese, julgamos (minha orientadora e eu) pertinente incluí-lo por tratarse de uma perspectiva que informará ao leitor dos nossos caminhos. Acreditamos que, para além do exigido, vale a pena inserir o necessário, uma vez que ele é também fruto da observação do trabalho desenvolvido no ENVELHECENTRO. A colocação deste ensaio após o primeiro artigo também respeita a cronologia de nossa produção acadêmica, a qual tem uma significação importante, pois fala de um amadurecimento das reflexões e das pesquisas.

Neste ensaio, intitulado "A sombra de um corpo que se anuncia: corpo, imagem e envelhecimento", feito em co-autoria com minha orientadora Junia Vilhena, e com Joana Novaes, e publicado na Revista Latinoamericana de 
Psicopatologia Fundamental, nossa proposta foi investigar as particularidades do sofrimento psíquico relacionadas ao fenômeno "ser velho" e seus impactos no sujeito, destacando o lidar com o desencontro entre o inconsciente atemporal e o corpo envelhecido.

Outra ideia presente no primeiro artigo, que ganhou uma atenção especial, posteriormente, transformando-se em um artigo dedicado exclusivamente a temática, foi a questão do trabalho do negativo como uma possível resposta às demandas sociais e psíquicas do envelhecer.

Podemos dizer que, atualmente, proliferam imagens e discursos que procuram criar uma tipologia homogeneizadora da população idosa. Apesar do envelhecer ser muito mais que um momento na vida do indivíduo, sendo, como já afirmei, um "processo" extremamente complexo e pouco conhecido, com implicações tanto para quem o vivencia como para a sociedade que a ele assiste (Fraiman, 1991). As singularidades deste processo são todas eclipsadas e a historicidade subjetiva do corpo é silenciada nos discursos "do mestre" que sabem exatamente o que o velho pensa e como este deve agir. Partimos do pressuposto que os discursos que normatizam o corpo tomam conta da vida simbólico-subjetiva do sujeito, não deixando espaço para a construção de uma narrativa individual.

Ao longo dos artigos enfocamos especialmente a questão do corpo porque este adquire, hoje, um estatuto essencial na construção de identidades, sendo alvo de preocupação constante por parte das várias camadas sociais. Como se vê, esta nova configuração traz consigo novos desafios e questões. Daí a necessidade de reflexão sobre os papéis adquiridos pela corporeidade e sobre os sentidos a ela atribuídos.

O corpo, nos dizia Levi Strauss (1974), é a melhor ferramenta para aferir a vida social de um povo. Ao corpo cabe algo muito além de ocupar um espaço no tempo. Cabe a ele uma linguagem que se institui antes daquilo que denominamos "falar", que se exprime, evoca e suscita uma gama de marcas e falas implícitas.

Bruno Latour é outro pensador que vê no corpo algo muito maior do que a mera "residência provisória de algo superior - uma alma imortal, o universal, ou pensamento - mas o que deixa uma trajetória dinâmica pela qual nós aprendemos a registrar e nos tornar sensíveis àquilo de que é feito o mundo", ou seja, seus símbolos, modos, culturas etc (Latour, 2009, p.39). 
Após várias décadas de historicização, desnaturalização e desconstrução das possibilidades de ocupar o corpo e ocupar-se do mesmo, as questões relativas aos usos do corpo ainda permanecem na ordem do dia, gerando inúmeras reflexões (Vilhena \& Novaes, 2012). Mediante todo tipo de iniciação ritual, o corpo é transformado em tabua da lei, em quadro vivo das regras e dos costumes, atores do teatro organizado por uma ordem social (Certeau, 1980). Partindo da premissa de que o corpo é uma construção social e historicamente datada, Kamper (2002) dirá que o corpo nunca está nu, nunca se apresenta desprovido de adereços, pois serve de suporte memorial para inscrições biográficas e valorativas de todos os tempos.

As formas de expressão dos sentimentos não são naturalmente dadas. Segundo Mauss (1921), têm a obrigatoriedade dos fatos sociais: "mais do que uma manifestação dos próprios sentimentos, é um modo de manifestá-los aos outros, pois assim é preciso fazer. Manifesta-se a si, exprimindo aos outros, por conta dos outros. É essencialmente uma ação simbólica" (p. 153).

Na sua vertente negativa, a perda da integridade corporal pode ser vista como uma morte simbólica e subjetiva. O que dizer de uma drástica mudança corporal, como aquela provocada por uma queda (um dos maiores receios do sujeito idoso) ou uma afecção orgânica que manifesta-se subitamente. Vários são os exemplos na literatura clássica que expressam essa constatação terrível em relação ao envelhecimento corporal. Montesquieu afirma a "infeliz condição dos homens" onde mal o espírito atinge a maturidade o corpo já começa a enfraquecer. François La Rochefoucauld lamenta que "a velhice é uma tirania que proíbe, sob pena de morte, todos os prazeres da juventude". Atribui-se a Platão a famosa frase "deve-se temer a velhice, porque ela nunca vem só. Bengalas são provas de idade e não de prudência”. Na verdade, este conceito de perda da integridade pode ser estendido, e todas as formas de desrespeito podem ser identificadas como uma espécie de morte, seja psíquica seja social (Vilhena, Rosa, Ibrahim e Petrelli, 2012).

Freud (1923) afirma que o eu é, antes de mais nada, um eu corporal, não sendo simplesmente uma entidade de superfície, mas, a projeção de uma superfície. Lacan (1998) vai mais longe e afirma que o inconsciente é o corpo. Por isso o corpo e seus usos apareceram aos nossos olhos como transgressão de um longo silêncio, imposto especialmente à velhice, já que o acesso à palavra e ao lugar do dizer não é uma questão simples. Eles transbordam nos discursos do corpo, criando assim uma narrativa de suas vidas (Vilhena, Novaes e Rosa, prelo). 
Mais uma questão trabalhada no primeiro artigo e aprofundada nos demais textos foi a criação de novas palavras para designar o fenômeno do envelhecimento tais como "melhor idade" e "terceira idade". Lacan (1969) chamou de "discurso" os laços sociais tecidos e estruturados pela linguagem. O discurso excede à palavra, vai mais além dos enunciados que realmente se pronunciam. Por essa razão dizemos que as palavras criam ou modelam os contextos nos quais estão inseridas. Kehl (2000) acrescenta ainda que a experiência compartilhada permite a troca de impressões e reflexões sobre o vivido que contribuem para alterar o campo simbólico, já que questionam verdades tidas como absolutas pela cultura.

O segundo artigo aqui apresentado, "Envelhecimento e seus possíveis destinos. Uma reflexão acerca do trabalho do negativo", também em coautoria com Junia Vilhena, e aceito para publicação na Revista do Tempo Psicanalítico, é o resultado do momento em que nos debruçamos mais detidamente sobre a questão do trabalho do negativo, segundo as referências de André Green, como uma possível lógica de funcionamento que, além de classicamente expressa nos estados limites, poderia ser observada também em alguns casos de velhos, especialmente do sexo masculino, cuja energia e disponibilidade para encarar a vida diminuem progressivamente. Este artigo conta ainda com as contribuições valiosas dos professores Joel Birman e Monah Winograd que estiveram presentes em meu exame de qualificação.

Retomamos as considerações que havíamos tecido em nosso primeiro artigo publicado e apresentamos agora um resgate bibliográfico mais consistente e embasado, articulando os autores mais eminentes do campo da psicanálise (Freud, Lacan, Roussillon e Green) com a letra fluida de escritores e poetas que também versaram sobre as dificuldades do envelhecer.

A face positiva da pulsão de morte é apresentada como possibilidade de estabelecimento dos limites inter e intra psíquicos. Um retorno ao narcisismo secundário é proposto como uma maneira estruturante de preservação do eu e gerenciamento das porções restritas de afeto, das perdas reais e imaginárias e do progressivo decaimento das funções corporais e executivas.

Aqui a discursividade entra como recurso fundamental para construção de uma narrativa sobre si mesmo e o mundo que o cerca. Aprendemos com Freud que o mundo é do discurso e apresenta um estranho excesso que funciona como uma 
abertura por desvelar que o fundamento de toda certeza é o caos da indeterminação do sentido, virtualidade constitutiva do próprio discurso (Vieira, 2001).

Posteriormente, minha atenção se volta para a inserção da velhice na cultura e seus desenvolvimentos. A questão do tempo ganha enfoque especial no texto Reflexos do tempo: uma reflexão sobre o envelhecimento nos dias de hoje, fruto de uma parceria com os colegas da psicologia social Lana Veras e Alysson Assunção, submetido à Revista Estudos e Pesquisas em Psicologia. Uma reflexão sobre as diferentes maneiras com as quais o sujeito e a sociedade encaram a passagem do tempo, as mudanças que isso acarreta na imagem corporal e o inexorável fim ao qual este percurso conduz. A arte é recrutada como ferramenta sutil de análise do extrato social. O imperativo do gozo, a medicalização da vida e o desamparo fundamental são problematizados nesse diálogo com a velhice e a morte.

Por fim, me volto agora para a questão do feminino nos processos de maturidade e envelhecimento. Resultado dos estudos e pesquisas bibliográficas levados a cabo durante o Doutorado Sanduíche na Universidade de Coimbra, o texto Eternamente jovens? Beleza e envelhecimento nos processos de subjetivação feminina, feito em coautoria com minha orientadora no Brasil, Junia Vilhena, e meu co-orientador estrangeiro, Eduardo Santos, e submetido à Psicologia em Revista, analisa os interditos que agora recaem sobre o envelhecimento, a decrepitude e a morte. Nossa proposta é que as tentativas de manter a aparência jovial, a qualquer custo, possam encarnar uma nova faceta da histeria freudiana, agora travestida de atuação, no corpo, como forma de cativar e manter o exigente olhar do Outro social, que se acostumou a valorizar a forma física jovem e magra, desconsiderando qualquer outro atributo intangível que as mulheres maduras e velhas possam possuir.

Os textos aqui presentes, parecem fazer coro ao pensamento de Bauman (1998) quando afirma que talvez o tempo que ele disponha seja curto demais, não por sua idade avançada, mas porque, quanto mais velho você é, mais sabe que os pensamentos, embora possam parecer grandiosos, jamais serão grandes o suficiente para abarcar a generosa prodigalidade da experiência humana, muito menos para explicá-la. Ainda assim, apesar de incompletos, os escritos que agora se seguem, tentarão abarcar parte dessa complexidade do fenômeno humano, recortando a última faixa etária da existência e algumas de suas singularidades. 
Preciso dizer que os artigos ora apresentados não representam a totalidade de minha produção durante o período do doutorado. Meu percurso foi enriquecido, nos últimos seis meses, com uma proveitosa estadia na Universidade de Coimbra, cujas atividades, reflexões e parcerias renderam uma participação, como orador, em um simpósio internacional sobre trabalho e envelhecimento, a publicação de um artigo de opinião na Plataforma Barômetro Social, intitulado "Velha infância", e a co-autoria em outro artigo sobre o envelhecimento nas zonas agrárias de Portugal "Redes de amigos e vizinhança como fator de proteção social para pessoas idosas isoladas: Estudo piloto em aldeias do concelho da Guarda", ambos colocados aqui como anexos.

Por fim, e para dar início, posso dizer que a iniciativa de pensar a subjetividade do idoso no âmbito acadêmico e científico visa, mais que ampliar conhecimentos, repensar o imaginário social de intolerância e exclusão em relação a população idosa. Perceber as diferentes nuances do envelhecimento na vivência subjetiva de homens e mulheres, tendo como pano de fundo as mudanças corporais, as possíveis limitações e dificuldades que isso pode acarretar nos relacionamentos, nas atividades exercidas, na sua autoimagem, enfim, na sua capacidade de existir prazerosamente, é contribuir para a compreensão e intervenção qualificada no atendimento de uma parcela significativa da sociedade, que historicamente tem sido relegada ao segundo ou terceiro planos nas políticas sociais e na formação de profissionais especializados. 


\title{
Primeiro Artigo - Silêncio, exclusão e morte: o trabalho do negativo na velhice
}

Artigo publicado na Revista Eletrônica Polêmica v. 13, n.1.p. 923-944.

Autor: Carlos Mendes Rosa

Recebido em: 09/04/2013

Aceito em: 17/01/2014

As referências bibliográficas foram mantidas no formato original da revista.

Resumo: Neste texto pretendemos abordar alguns aspectos relacionados com o envelhecimento na sociedade atual, ressaltando as dificuldades que a sociedade possui em lidar com este fenômeno natural que é o envelhecer. $\mathrm{O}$ artigo busca ainda pensar o trabalho do negativo em psicanálise como possível saída simbólica para a condição social e psíquica da velhice.

Palavras-chave: Velhice, exclusão, trabalho do negativo

Silence, exclusion and death: the negative work in old age

\begin{abstract}
In this paper we aim to address some aspects of aging in today's society, especially the difficulties that society has to deal with this natural phenomenon which is growing older. The article tries to think the work of negative in psychoanalysis as possible symbolic way out of the social and mental condition of old age.
\end{abstract}

Keywords: Aging, exclusion, negative work

Alguns podem até dizer que estamos comemorando dez anos do Estatuto do Idoso e muitos progressos foram feitos no sentido de uma melhor aceitação dos velhos no convívio social. Entretanto, o que notamos com tristeza é a existência de muitos preconceitos em relação aos velhos. 
Talvez muitos estejam mascarados por rótulos e programas populistas, mas o preconceito existe. Ele se expressa em várias atitudes do cotidiano como a exclusão social, o apagamento subjetivo, o desinteresse pela história de vida e o medo do contato com a morte, figura tão estreitamente ligada à velhice.

Tentaremos colocar em evidência estas questões com a finalidade de pensar possíveis mecanismos psíquicos e simbólicos que deem conta desta condição social. Para tanto, vamos nos servir dos conceitos de Roussillon e Green acerca do trabalho do negativo. Essas teorias tentam explicar as diferentes formas de elaboração da pulsão que perde o interesse pelo mundo e se volta para o próprio sujeito. Um processo de retraimento que a ingratidão do mundo e a pouca aceitação da sociedade em relação aos velhos podem acelerar ou incentivar.

\section{Afastando os velhos do convívio}

A primeira faceta do preconceito que podemos observar é o fato de que quanto mais se vive biologicamente neste modelo societário, menor é o reconhecimento simbólico. Talvez, por isto, cada vez mais aumentem os investimentos naquilo que alguns sociólogos chamam de adultescência -, a eterna busca pela aparência jovem seja no corpo, seja nas roupas, seja no estilo de vida. Como se o velho só pudesse existir socialmente sob a roupagem de uma juvenilidade mercadológica. Triste cenário no qual todas as representações já se encontram dadas e estabelecidas, como se não fosse lícito ao velho ser diferente daquilo que a sociedade espera dele.

A antropologia cultural e social moderna mostra que a velhice não deve ser considerada apenas em seus aspectos físicos e cronológicos, mas sim como uma representação social (Geertz, 1996). Destaque-se a memória entendida como um fenômeno social. A tarefa de lembrar ou relembrar é tanto ou mais frutífera quanto maior for sua relevância e inserção na sociedade e no contexto histórico-cultural. São as lembranças dos velhos em nossa cultura relevantes ou positivamente qualificadas?

É sabido que a sociedade moderna tende a tratar os velhos com desprezo devido ao declínio em suas forças e capacidades. No entanto, essa marginalização do velho não parece ocorrer em todas as culturas. Ironicamente, apenas naquelas que já atingiram um determinado grau de desenvolvimento. Segundo Gebran (1999) as chamadas "sociedades ágrafas" valorizam e reverenciam o saber e o fazer 
daqueles que já acumularam experiência através dos muitos anos vividos. Este fato se relaciona com a transmissão dos conhecimentos necessários à continuidade da cultura pelos mais novos. De sorte que nestes povos ágrafos a única maneira de se adquirir o saber, na ausência de qualquer representação escrita (livros, jornais, computadores, etc), é perguntando e escutando o que os mais velhos têm para ensinar.

Nesse sentido Benjamin (1936) fala do valor que a experiência possuía nas sociedades anteriores ao advento da imprensa. A experiência transmitida de pessoa a pessoa era a fonte a que recorriam todos os narradores. Estes narradores eram os grandes responsáveis pela perpetuação e circulação do conhecimento. Distinguiamse em duas categorias; os camponeses, que permaneciam estacionários em suas terras e herdavam o saber milenar que ouviram seus antepassados contarem; e os marinheiros, que cruzavam as terras do mundo e voltavam com o relato de aventuras que eram ouvidas com interesse por aqueles que em terra ficavam.

Nossa contemporaneidade parece ter silenciado os relatos narrativos, transferindo-os para os papéis de circulação impressos nos jornais e, nestes tempos virtuais, nos incontáveis escaninhos virtuais (Rosa e Zamora, 2012). Benjamin (1933) situa essa mudança na maneira de lidar com o relato no início do século passado, mais notadamente durante a $1^{a}$ Guerra Mundial. O autor conta que os combatentes, que em outras guerras milenares possuíam feitos nobres e dignos de fazerem seus nomes ecoarem pela eternidade, voltaram silenciosos dos campos de batalha, pobres em experiências comunicáveis. Internalizaram as emoções indescritivelmente dolorosas de um evento sinistro para a humanidade.

Aproveitando este estado de silêncio das pessoas, o sistema econômico tratou de valorizar outras maneiras de expressão e formação de conhecimentos. Assistimos então à propagação da mídia e da indústria cultural, agora novas fontes de conhecimento e modeladores de uma sociedade que não mais fala, não mais questiona, tampouco expressa suas emoções; só aceita. A esse processo de interiorização das emoções, das regras e da disciplina, Foucault (1977) denominou de “tecnologias do self”. Nas palavras do autor: “a eficácia das práticas disciplinares é maior quando não são vividas como demandas externas ao sujeito, mas como comportamentos auto-gerados e auto-regulados" (p.136).

\section{A terceira idade e outros nomes}


O aumento da expectativa de vida da população mundial faz crescer também o número de pessoas velhas em todos os países. No Brasil as pessoas com mais de 60 anos são hoje 12,6\% da população, segundo dados do IBGE (Brasil, 2010). Além disso, essa fatia da população está economicamente muito mais ativa que em outras épocas da história.

Estes fatores conjugados constroem um quadro novo dentro das sociedades contemporâneas onde a velhice passa a ser vista com outros olhos e ganha novos nomes. Aqui encontramos a segunda forma de preconceito, travestida pela suavização do conceito. Na "moderna pedagogia" da terceira idade criam-se atividades exclusivas para os velhos que vão da universidade às academias de dança, deixando de lado o fato de que o enriquece a vida é exatamente o contato com as outras gerações, os novos amigos, o fazer e trocar experiências distintas.

A invenção da terceira idade revela uma experiência inusitada de envelhecimento, cujo entendimento não pode ser reduzido apenas aos indicadores de prolongamento da vida na sociedade contemporânea, mas fala claramente de uma nova "comunidade de aposentados" relativamente significativa para a sociedade geral, em termos de condições físicas, psíquicas e financeiras. Pessoas dispostas a tornar reais as expectativas de que essa etapa da vida é propícia às realizações e satisfações pessoais que outrora foram relegadas a segundo plano (Debert, 1999).

Alguns autores chegam até a falar de uma descronologização da vida contemporânea, dada a uniformização de práticas e expectativas entre diferentes etapas da vida e categorias de idade. Enquanto na pré-modernidade a idade cronológica é menos relevante que o status da família na determinação do grau de maturidade e dos recursos de poder, a modernidade apresenta a vida estritamente dependente do cronos e a pós-modernidade opera a desconstrução do curso da vida em nome de um estilo unietário.

Fenômenos como a dispersão de conteúdo eletrônico e seus impactos na vida cotidiana, a informatização da economia e a fluidez e multiplicidade de estilos de vida, frutos de uma sociedade muito mais ancorada no consumo do que na produtividade, corroboram para esse embaçamento das classes de idade. O que acaba por transformar a idade cronológica em um poderoso mecanismo de criação de atores políticos, bem como definidor de novos mercados de consumo. 
Norbert Elias (1992) analisa que entre a sociedade da nobreza que se compunha de guerreiros e a doutrina rousseauniana da piedade e da comiseração, emergiu um sentimento de "compartilhamento" do sofrimento de todo e qualquer ser vivo. Sentimento até então ausente na sociedade, pois o sofrimento e a miséria eram estados da natureza. Na constituição das sociedades modernas a ideia do homem despossuído passa a figurar como um incômodo que o Estado deve enfrentar e eliminar. Por essa lógica a velhice, a loucura e outros males passam a ser objeto do cuidado e da assistência do poder público.

No entanto, mesmo essa dimensão cuidadora parece ficar eclipsada com o neoliberalismo, transformando os novos governos em baluartes da sociedade do espetáculo, que prega o ideário de sujeitos jovens, felizes e eficientes, relegando à condição de excluídos da polis aqueles cujas formas e aspecto não se enquadram nos padrões de perfeição contemporâneos. Não raro estes podem ser alvo de programas assistencialistas que muitas vezes não resgatam a cidadania, mas promovem a manutenção da exclusão e da alienação.

Muito acreditam que as imagens e formas de gestão da velhice na contemporaneidade reescrevem e modificam os estereótipos pelos quais o envelhecimento é tratado, desestabilizando imagens culturais tradicionais, apresentando um quadro mais positivo do envelhecimento, que passa a ser concebido como uma experiência na qual a doença física e o declínio mental, considerados fenômenos normais nesse estágio da vida, são redefinidos como condições gerais que afetam as pessoas em qualquer fase. Dessa maneira, abrem espaço para que novas experiências de envelhecimento possam ser vividas coletivamente.

É evidente que esta maneira de pensar a velhice é uma visada bastante otimista da sociedade atual, que não apenas permite, mas também encoraja a diferença. Além de incorrer no risco de fazer coro com as correntes interessadas em transformar o envelhecimento em mercado de consumo, através da promessa que a velhice pode ser eternamente adiada com a adoção de estilos de vida e formas de consumo adequadas. Como afirma Debert (1999) as oposições entre "velho jovem" e "velho velho" são formas de estabelecer laços simbólicos entre indivíduos, criando mecanismos de diferenciação, em um mundo no qual a obliteração das fronteiras entre grupos é acompanhada da afirmação, cada vez mais pregnante, da heterogeneidade e das particularidades locais. 
A autora defende ainda que o fato dos velhos constituírem o grupo que possui a maior disponibilidade para o consumo, aliado ao imaginário (atual) da velhice como momento privilegiado para realização pessoal, e à concepção autopreservacionista do corpo, que não apenas responsabiliza os sujeitos por sua imagem, como convoca-os a conservarem seus corpos belos e "jovens" como requisito para exposição dos mesmos na sociedade, dão os contornos da socialização e reprivatização da velhice no contexto brasileiro.

Uma atualização da "conspiração do silêncio" descrita por Simone de Beauvoir, agora travestida de positivação do envelhecimento, que tanto exclui e reduz a subjetividade do sujeito idoso, quanto o fazia o silêncio imposto pela sociedade moderna que temia a morte acima de qualquer coisa, a ponto de evitar sequer falar da finitude da vida. Como argumenta Arendt (1972), cabe aos mais velhos dar ao novo e, portanto, estranho ser que acaba de chegar ao mundo, os elementos que o instituirão na cultura. Assim, caberia aos mais velhos a tarefa da transmissão. Mas, tratando-se de relações igualitárias - nas quais não só na família, mas também na escola, as diferenças inter-geracionais parecem desaparecer, e pais e filhos, professores e alunos se tratam de igual para igual em nome da democratização destas relações -, que transmissão é possível? Onde, neste caso, se apoia, simbolicamente, a transmissão? Se é que a mesma ainda resta possível.

De ambos os lados da moeda-, o isolamento pelo medo da morte, ou a pasteurização da velhice através do prolongamento da juventude, e não obstante a cultura da sociedade unietária, observamos ainda muito preconceito velado em relação ao velho, fruto de uma sociedade marcada pelos corpos eficientes, magros e jovens. Preconceito esse que se oculta por trás dos novos nomes dados à velhice, como "terceira idade" ou "melhor idade". Produtos desta sociedade do espetáculo que, ancorada na massiva difusão da indústria cultural, desacostuma o nosso olhar em relação à feiura: gordos, pobres, velhos e loucos,- novos párias sociais!

\section{O trabalho do negativo na velhice}

À medida que o sujeito envelhece ele costuma apresentar um progressivo desinvestimento libidinal das coisas do mundo com consequente investimento no próprio sujeito. Uma lógica semelhante é detalhada por Freud (1914) no texto sobre o narcisismo. $\mathrm{O}$ inventor da psicanálise afirmava que em alguns casos de doença 
orgânica a libido direcionada para o mundo externo regride ao eu como suporte à condição sofrente.

O corpo, na velhice, é o lugar privilegiado de desilusão narcísica, prometido à decadência, é palco do adoecer, empurrando o sujeito para o desafio de manter a aposta na vida. Uma vez que a libido agora se encontra escassa e o sujeito necessita de um mínimo de investimento narcísico para sobreviver, ele retira parte, ou toda nos casos mais graves, da libido do mundo externo e passa a se interessar cada vez mais por suas memórias, suas fantasias e suas próprias dores, que usualmente são várias e frequentes.

Alguns fenômenos típicos da velhice como o retraimento de interesses, um certo egoísmo e a despreocupação com os fenômenos ao seu redor são confirmações desse remanejamento libidinal para o próprio eu (Gabbay, 1999). Tentaremos aqui traçar um paralelo entre esse desinvestimento narcísico e o trabalho do negativo, especialmente no tocante à função desobjetalizante da pulsão.

André Green (2009) define como trabalho do negativo o conjunto de operações psíquicas que tem como protótipo o recalque, e como variações a negação, o desmentido e a foraclusão. $O$ trabalho do negativo se estende ao conjunto das instâncias do aparelho psíquico; id, ego e superego. Entre os dois extremos do recalque bem constituído à radicalidade da foraclusão, o trabalho do negativo pode seguir caminhos intermediários como a clivagem e a denegação.

Green (1988) entende que em muitos casos, tanto no âmbito normal quanto patológico, não podemos considerar todo o trabalho psíquico que se elabora ali, como sendo determinado exclusivamente pelo jogo pulsional. Nos parece certo que a parte assumida pelo objeto nessa elaboração configura-se como um fator de interferência que entra em jogo na constituição da subjetividade por efeitos fora do comum. Se o objeto é responsável por conter e estimular a pulsão, essa dupla ação só se torna possível a partir de um trabalho do negativo estruturante.

Freud (1925) em seu texto sobre "A negativa" afirma que o pensamento tem a capacidade de apresentar à mente aquilo que foi percebido outrora, reproduzindoa por uma representação sem que o objeto externo deva estar necessariamente presente. É a passagem do princípio do prazer para o princípio da realidade. O momento onde o sujeito percebe que não é importante, somente, que ele possua um atributo "bom" e que o integre ao seu ego, mas que, esse atributo corresponda a uma coisa no mundo externo e que dela possa se apossar quando necessário. Green 
(1988) comenta ainda que a expulsão do mau permite a criação de um espaço interno no qual o eu, como organização, pode nascer para a instauração de uma ordem fundada no estabelecimento de ligações relacionadas a experiências de satisfação. Essa organização facilita o reconhecimento do objeto em estado separado no espaço do não eu e o seu reencontro.

Nesse sentido, Roussillon (2010) comenta que o trabalho de transformação da experiência primária, através da simbolização, à qual trataremos mais adiante, tem uma dupla função de transformá-la em algo apropriado pelo sujeito, e torna-la perdida para sempre, na medida em que ela transforma o próprio sujeito. Aqui podemos lembrar Heráclito quando afirma que "nenhum homem pode atravessar o mesmo rio duas vezes, porque nem o homem nem o rio são os mesmos".

As investigações de André Green sobre o trabalho do negativo o conduziram à clínica do vazio, onde se encontra uma espécie de mistura de desinvestimento, de destrutividade inaceitável e de identificação com um objeto destruído pela separação. Esse desinvestimento narcísico nos parece claro em muitos casos de idosos cujo interesse pelo mundo exterior cai drasticamente com a chegada da aposentadoria e o alijamento do universo do trabalho. De modo que tentaremos interpor aqui as considerações sobre os estados narcísicos e a dinâmica do envelhecimento, especialmente dos sujeitos do sexo masculino, pois nos parece que a mulher idosa encontra meios mais positivos para lidar com essa nova realidade.

$\mathrm{O}$ sujeito que sofre algum tipo de perda realmente significativa para sua economia libidinal; seja um amor, um ideal, ou uma capacidade. Encontra-se obrigado pelo teste de realidade, a um trabalho lento e penoso de desligamento do objeto amado. Freud (1915) escreve que durante este processo o sujeito em luto direciona a maior parte de seus pensamentos (quando não todos eles) para o objeto perdido, com o intuito de mantê-lo próximo de si, ainda que seja só por mais algum tempo. A libido objetal que se direcionava para o mundo externo é revertida para o eu como forma de dar a mesma novo sentido, pela via das novas identificações que se formarão a partir de então. Identificações essas que têm por função desinvestir cada lembrança e cada afeto relacionados ao objeto faltante. As condições muitas vezes limitadoras do "ser velho", somadas às perdas reais de pessoas, de forças, de saúde, às perdas imaginárias de amor, de tempo, de vida e às perdas simbólicas que falam do status subjetivo, dos papéis sociais e do lugar na família, constituem um emaranhado de objetos faltantes dos quais o sujeito terá que se separar 
psiquicamente, não sem um cadinho de elaboração, caso possua meios para tanto, e de sofrimento.

Segundo aponta Zornig (2008), esse desinvestimento trata de uma perda experimentada em âmbito narcísico e não edípico, pois ocorre uma descatexia central do objeto primário materno. Aquilo que Green (2009) denomina de complexo da mãe morta refere-se a uma depressão que tem lugar na presença do objeto, onde a tristeza da mãe e a diminuição de seu interesse pelo seu bebê estão em primeiro plano. Esta indicação enfatiza a sutileza da relação mãe-bebê, que pode funcionar como um referencial de base afetiva ou ser pautada pela vivência de ausência e de vazio.

Virginia Woolf narra o desencanto provocado pelo desencontro subjetivo da imagem corporal com o inconsciente que a determina em seu conto da Dama no Espelho. Seu rosto transformara-se na máscara de uma velha. Ao continuar se olhando, teve a sensação de ser alguma coisa seca por fora, como um figo seco, incapaz de produzir admiração ou prazer. Internamente, não se sentia uma fruta fora da estação, como se percebia externamente (Woolf, 2005).

O trabalho do negativo pode ser entendido como expressão da pulsão de morte, de sorte que sua tarefa consiste nas atividades de negativização, de rompimento, desligamento e desobjetalização. Green (1988) comenta que para poder dizer sim a si mesmo é preciso poder dizer não ao objeto. É através deste ato de dizer não que os limites psíquicos podem se estabelecer, favorecendo a capacidade de representação e a constituição subjetiva. Mendes e Gracia (2012) acrescentam que o conceito de trabalho do negativo traz a ideia de que toda negação pode ser estruturante ou patológica dependendo em que condições e em que contexto este "não" se dá. Negar a finitude da existência, distanciar-se do convívio social cada vez mais exigente com um corpo e espírito alquebrados, parece uma forma muito interessante de aplicação do trabalho do negativo.

No texto Reflexões para os tempos de guerra e morte, Freud (1915a) apresenta-nos sua preocupação para com o tema da morte, já que como "criaturas civilizadas, tendemos a ignorar a morte como parte da vida". Como Freud mesmo nos fala nesse texto, na verdade, nenhum de nós acredita na própria morte e nem mesmo consegue imaginá-la.

Um ano antes, ao discorrer sobre a transitoriedade, Freud já nos avisara que exigência de imortalidade, por ser tão obviamente um produto dos nossos desejos, 
não pode reivindicar seu direito à realidade (Freud, 1915b). Todos nós padecemos do medo da perda dos nossos objetos de investimento afetivo. A perda relaciona-se em última análise com o receio da morte, ou seja, a perda da existência (Vilhena et al, 2013).

As operações negativizantes, colocadas em cena pela pulsão de morte através da função desobjetalizante, não comportam uma dimensão puramente destrutiva, mas são também fundamentais no trabalho do negativo em sua função de estruturar os limites intra e inter-psíquicos e os processos de simbolização. Quando bem sucedidos favorecem processos sofisticados como a construção de representações, a simbolização e a abstração; processos esses que se constituem como fundamentais a uma teoria sobre o pensamento (Garcia e Damous, 2009).

O objetivo objetalizante (besetzung) das pulsões de vida ou de amor tem como principal consequência realizar, pela mediação da função sexual, a simbolização. A ausência de simbolização se configura como uma forma de resistência, uma forma de oposição ao processo psíquico. Aliada ao trabalho de preservação das poucas energias restantes na última fase da vida, o trabalho de desinvestimento libidinal pode se configurar com uma possível saída, defesa contra o inevitável.

Aproveitar esse distanciamento que a velhice traz em relação ao cotidiano e suas pressões deve ser algo valioso para os velhos e não pode ser tido como sinônimo de incapacidade e signo de exclusão. Por que nossa cultura valoriza tanto o brincar da criança, que se retira da realidade para uma área de experimentação e construção imaginária, e não consegue aceitar que o adulto possa também necessitar desta mesma imersão na fantasia quando atinge determinada idade?

Incentivar essa melhor aceitação das novas possibilidades na velhice não deve ser confundido com a infantilização do velho. Pois isso seria equivalente a colocar o adulto jovem em posição superior de conhecimentos e discernimento, como acontece realmente com a criança. Tal postura desconsidera todo arcabouço de conhecimentos e experiência que a velhice proporciona, o que definitivamente é um equívoco.

\section{Simbolizar a ausência para sobreviver}

Roussillon (2013) afirma que a simbolização passou a ser uma questão problemática dentro da teoria psicanalítica na medida em que se percebeu que nem 
tudo que o sujeito experimenta como vivência é automaticamente representado ou simbolizado. É preciso que exista certo trabalho psíquico na direção do objeto e sua relação com o sujeito.

O autor define que a simbolização leva a uma espécie de representação do processo psíquico que ocorre em três tempos distintos e sucessivos. O primeiro no qual a experiência subjetiva é capturada psiquicamente e inscrita, um segundo tempo no qual a experiência é ligada afetivamente e simbolizada enquanto representação coisa, ou seja, neste processo o traço primário é religado à representação coisa. E uma última etapa onde a representação coisa é religada a representação palavra, sendo transferida para o aparelho de linguagem e ganhando um sentido próprio, que se pode dizer único, para o sujeito (Roussillon, 2013).

$\mathrm{Na}$ prática podemos ver isso ocorrer com idosos quando dizem que “palavras são tudo o que me restam”. Quando narram suas histórias para os mais novos, muitas vezes pouco interessados em escutar, como forma de reviver e recuperar um passado perdido.

Um exemplo interessante da capacidade da representação palavra para manter o afeto ligado ao traço primário pode ser visto nas diversas oficinas de palavras com idosos. Cuja proposta é fazer o idoso falar de seu cotidiano, e paulatinamente ir se apropriando, através da fala, das suas lembranças, primeiro as recentes, passando pelos eventos anteriores até chegar aos conteúdos infantis de cada participante. Este trabalho, realizado em grupo operativo, tem a função de preservar a sanidade e a memória do idoso.

Parece fundamental para o nosso estudo compreender que os modos elaborados de simbolização podem se dar na ausência do objeto simbolizado, desde que um trabalho de simbolização primário tenha sido efetuado, tendo como condição prévia o encontro do sujeito com o referido (representado) objeto.

No caso específico do envelhecimento faz todo sentido pensar que o velho têm condições de enriquecer o seu mundo interno com representações das coisas que ficaram perdidas ao longo do processo de envelhecimento, simbolizando e historicizando as ausências/faltas.

Representar é apresentar de novo, é situar dentro do tempo e da história a experiência subjetiva, permitindo que a experiência emocional não mais atravesse a psique sem estar subjetivamente ligada e religada aos objetos. O processo de representação dá condições para que o sujeito se aproprie disso que o constitui e os 
modos pelos quais transforma aquilo que encontra em seu caminho. Em outras palavras, Roussillon (2013) dirá que o processo de simbolização começa aprèscoup, quando o sujeito pode dar a si mesmo uma cópia, uma espécie de “apresentação" daquilo que aconteceu em sua própria vida.

Em psicanálise acredita-se que o sujeito se apropria de sua condição sempre de forma peculiar, e só a análise da narrativa particular daquele sujeito é capaz de deslindar os meandros do seu sintoma. Em tempos de patologização da normalidade, o fenômeno biológico do amadurecimento ganha status de doença e promove efeitos sintomáticos particularizados nos velhos. Daí a necessidade, mais uma vez, de se colocar em palavras estes efeitos com o objetivo de descontruir ou reelaborar as angústias e dores advindas da condição de estar velho (Vilhena et al, 2013).

De preferência, que esta elaboração ocorra sem cair na noção de estigma ou doença e tampouco sem a tentativa de suavizar uma condição natural, que naturalmente traz mais dificuldades ao sujeito, dando-lhe novos nomes que não façam jus a seu status, tal como a nomenclatura "melhor idade".

\section{Referências}

Benjamin, W. (1936). O Narrador. In: Obras escolhidas 1. São Paulo: Brasiliense.

Benjamin, W. (1933). Experiência e pobreza. In: Obras escolhidas 1. São Paulo: Brasiliense.

Debert, G. (2004) A Reinvenção da velhice. São Paulo. EDUSP.

Elias, N. (1992) A solidão dos Moribundos. Rio de Janeiro, Zahar.

Foucault, M. (1977) A microfísica do poder. Rio de Janeiro: Graal.

Freud, S. (1914) Sobre o Narcisismo: uma introdução. In: Edição Eletrônica Brasileira das Obras Psicológicas Completas de Sigmund Freud, Rio de Janeiro, Imago. Vol. XIV. 2000.

Freud, S. (1915a) Reflexões para os tempos de guerra e morte - II: Nossa atitude para com a morte. In: Edição Eletrônica Brasileira das Obras Psicológicas Completas de Sigmund Freud, Rio de Janeiro, Imago. Vol. XXII. 2000.

Freud, S. (1915b). Sobre a transitoriedade. In: Edição Eletrônica Brasileira das Obras Psicológicas Completas de Sigmund Freud. Vol. XIV. Rio de Janeiro: Imago. Freud, S. (1925) A negativa. In: Edição Eletrônica Brasileira das Obras Psicológicas Completas de Sigmund Freud, Rio de Janeiro, Imago. Vol. XIX. 2000. 
Gabbay, R. (1999) Considerações sobre psicanálise com idosos. Anais da Primeira Jornada de Psicanálise com Idosos e suas Interseções, p. 31-31. Rio de Janeiro: Escola Brasileira de Psicanálise Movimento Freudiano.

Garcia, C. A.; Damous, I. (2009) O silêncio no psiquismo: uma manifestação do trabalho do negativo patológico

Gebran, P. (1999) Velhos nas sociedades ágrafas. Anais da Primeira Jornada de Psicanálise com Idosos e suas Interseções, p. 20-30. Rio de Janeiro: Escola Brasileira de Psicanálise Movimento Freudiano.

Geertz, C. (1996) Representações simbólicas. Rio de Janeiro, Zahar.

Green, A. (1988) Seminário sobre o trabalho do negativo. Anexo 3. In: Green, A. O trabalho do negativo. Porto Alegre: Artmed, 2009.

Green, A. (2009) O trabalho do negativo. Porto Alegre: Artmed.

IBGE. Censo Demográfico 2010. Disponível em: <http://www.censo2010.ibge.gov.br>.

Mendes, L. C.; Garcia, C. A. (2012) Os destinos do trabalho do negativo nas patologias limítrofes. Psicologia em Revista, Belo Horizonte, v. 18, n. 2, p. 277 292, ago. 2012.

Rosa, C. M.; Zamora, M. H. (2012) Usos da internet: algumas reflexões éticopolíticas. Revista Polêm!ca, v. 11, n. 4.

Roussillon, R. (2010) A capacidade de criar e a exigência de criar. Jornal de Psicanálise, v. 43(79), p. 237-256.

Roussillon, R. (2013) Le processus de symbolisation et ses étapes. Disponível em http://psycho.univ-lyon2.fr/sites/psycho/IMG/pdf/doc-226.pdf acessado em 11 de junho de 2013.

Vilhena, J.; Rosa, C. M.; Novaes, J. V. (2013) Para além dos anos vividos. Uma leitura das categorias clínico-discursivas acerca da velhice. In: Pocinho, R., Santos, E. (orgs) Envelhecer hoje, conceitos e práticas. Coimbra, Legis.

Vilhena, J. \& Novaes, J.V. (2009) Un corps à la recherche d'un logement. Corps, violence et médecin. In: Masson, C. \& Desprat-Pequignot. C (orgs) Le corps contemporain: créations et faits de culture. Paris, L’Harmatan. p.113-136.

Woolf, V. (2005) A Dama no Espelho: Reflexo e Reflexão. Contos Completos. São Paulo. Cosac Naif.

Zornig, S. M. A. (2008) A corporeidade na clínica: algumas observações sobre os primórdios do psiquismo. Rev. do Tempo Psicanalitico, v.40.2. 


\section{Ensaio - A sombra de um corpo que se anuncia: corpo, imagem e envelhecimento}

Artigo publicado na Revista Latinoamericana de Psicopatologia Fundamental, 17(2), 251-264, jun. 2014.

Autores: Junia Vilhena, Joana Vilhena Novaes, Carlos Mendes Rosa

Recebido em: 30/04/2013

Aceito em: 25/07/2013

As referências bibliográficas foram mantidas no formato original da revista.

\section{Resumo}

A velhice tem várias facetas e preconceitos associados ao que representa. Nosso objetivo é refletir acerca das peculiaridades relacionadas ao fenômeno ser velho e seus impactos no sujeito, destacando o lidar com o desencontro entre o inconsciente atemporal e o corpo envelhecido, chamado de envelhescência. Partimos do pressuposto que os discursos que normatizam o corpo tomam conta da vida simbólico-subjetiva do sujeito, não deixando espaço para a construção de uma narrativa individual.

Palavras-chave: Envelhecimento, corpo, morte, psicanálise

Reduzidos a um único tempo verbal, o pretérito, com suspeito presente e um futuro que ninguém quer.

Eliane Brum

\section{Introdução}

Não deve ter escapado ao leitor os inúmeros vocábulos que veem substituindo o termo velho: idoso, maduro, terceira idade e, finalmente, melhor idade. Por quê? Porque na sociedade ocidental capitalista ninguém quer ser velho. Ser velho é sinônimo de incapacidade física e intelectual, dependência, decadência física, psíquica e por aí vai. Criam-se então novas palavras, conceitos de idoso, terceira idade, como se fosse possível classificar os seres humanos por faixa etária como classificamos, perversamente, os países segundo seu grau de 
desenvolvimento e pobreza. Primeiro mundo, terceiro mundo... É neste que está a velhice ou a terceira idade.

A velhice tem um tempo, um nome, um status, várias facetas e muito preconceito associado a tudo que a ela se relaciona. Nosso objetivo é refletir criticamente acerca destas peculiaridades relacionadas ao fenômeno "ser velho" e seus impactos no sujeito. Os eufemismos que mascaram a relação automática entre envelhecimento e envilecimento no imaginário social partilhado, a drástica mudança na relação do sujeito velho com o tempo e as demais construções culturais associadas, agenciam subjetividades e incidem sobre o nosso fazer clínico.

A terceira idade é o terceiro mundo da política ou da vida. É um peso morto gestionário, socialmente marginal, cujos custos, quando não estão alimentando a indústria do turismo para $3^{\mathrm{a}}$ idade, dos cosméticos ou do body fitness, representam um "peso" muito grande na balança de pagamentos da previdência. Quanto mais se vive biologicamente neste modelo societário, menor é o reconhecimento simbólico. Talvez, por isto, cada vez mais aumentem os investimentos naquilo que alguns sociólogos chamam de adultescência -, a eterna busca pela aparência jovem, seja no corpo, seja nas roupas, seja no estilo de vida. Como se o velho só pudesse existir socialmente sob a roupagem de uma juvenilidade mercadológica.

Contudo, a juvenilidade não pode ser confundida com jovialidade. A primeira é biológica enquanto a segunda é existencial e simbólica. Jovialidade é um nome que inscreve uma condição divina — vem de Júpiter —, no latim jovis. Outro nome para alegria, para a aceitação da vida tal qual ela nos aparece, como uma nuance da morte. Na alegria da jovialidade moço e velho se reencontram, trocam e podem sentir a mesma saudade que em vida se sente da vida, de partes nossas, saudades das partes corporais, de partes espirituais, que morrem ao longo da existência.

A antropologia cultural e social moderna (Geertz, 1996) nos diz que a velhice não deve ser considerada apenas em seus aspectos físicos e cronológicos, mas sim como uma representação social. E por que não simbólica também? Destaquemos a memória, entendida como um fenômeno social, e suponhamos que a tarefa de lembrar ou relembrar seja tanto ou mais frutífera quanto maior for sua relevância e inserção na sociedade e no contexto histórico-cultural. São as lembranças dos velhos, em nossa cultura, relevantes ou positivamente qualificadas? 
Na cultura ocidental moderna o velho nada tem mais a dizer que não seja no plano biológico. Ele é o infans. E não tem, porque lhe falta a autoridade. Não existe mais entre nós a cultura da ancestralidade ainda presente em algumas comunidades litúrgicas de afrodescendentes (a figura do Egum) ou mesmo em culturas orientais. Ainda que, até nesta última, o lugar simbólico do ancião também está sendo demolido.

A autoridade decorre de uma forte presença simbólica em torno da qual giram os eixos e valores éticos de um grupo. Neste modelo os anos vividos transformam-se em experiência e o velho é alguém pleno de valor. Há aí uma inclusão social, uma inclusão simbólica da morte e, como sabemos, só a inclusão da morte na vida e no espaço social garantirá uma aliança entre vivos e mortos. Daí decorre a autoridade do velho. O morto (estar velho é estar perto da morte) vai ser ancestral. E o que é o ancestral se não alguém que vai ser a voz da fundação que cada um dos vivos, dos filhos, vai carregar para continuar mantendo os laços sociais de um grupo. Como aponta Moniz Sodré, cada grupo carrega, de certo modo narcisicamente, a voz de sua fundação (comunicação pessoal).

Disso, aliás, já nos falava Freud em diferentes formas como veremos a seguir. Isto significa que a morte integra o ciclo social das trocas simbólicas. Em um livro, A troca simbólica e a morte, Baudrillard (1997) diz que é no século XVI que essa figura moderna da morte se generaliza, porque antes a morte era festejada. Ao observarmos as imagens da Idade Média vemos dançando o rei, a corte, o guerreiro e a morte, representada pelo esqueleto dançando junto com as pessoas.

No entanto, parece que teremos de lutar por esse direito de ficar velho em paz. De exercer as prerrogativas da velhice e não nos preocuparmos... De lidar com o desencontro entre o inconsciente atemporal e o corpo, âmbito da temporalidade, ou por um encontro da alma sem idade com o corpo que envelhece, como aponta Berlinck (2000) ao cunhar o termo envelhescência.

\section{Pensando psicanaliticamente a velhice}

Freud caminhava com um jovem poeta e ouvia suas lamentações acerca da transitoriedade da beleza neste mundo, onde, segundo este, tudo que é belo terá seu fim um dia. A partir deste diálogo escreve um texto, quase poético, estendendo as reflexões sobre o tema da transitoriedade para outros aspectos da vida humana. Pensar a velhice hoje, além das reflexões necessárias de caráter político, como a 
mudança de perspectiva do cuidado ao velho que passou da esfera privada para a esfera pública, e a exclusão social decorrente das diferentes faixas etárias, e as de ordem subjetiva, como as construções ou representações sociais que tendem a homogeneizar essa população, parece suscitar a questão do que é transitório.

Se antes falávamos da velhice em termos apenas de perdas cognitivas e executivas, hoje comemoramos entusiasmados as conquistas da medicina e os avanços legais e sociais de alguns países na defesa dos direitos dos velhos.

Atualmente um dos principais ritos de passagem que anunciava a chegada da terceira idade, a perda da libido, está perdendo autoridade. A libido, seja por uma maior liberalização dos costumes, seja por progressos da medicina, reclama seus direitos na terceira idade. Esmaece a fronteira entre as fases da vida. Envelhecer como sinônimo de decadência deixou de ser uma profecia autorrealizadora. Mas sabemos que tal como a bela paisagem contemplada pelo amigo de Freud, quando sobrevier o inverno da alma, estas maravilhas, estes avanços, rapidamente serão solapados pela inexorabilidade do processo vital.

Freud (1914/2000) afirmava que em alguns casos de doença orgânica a libido direcionada para o mundo externo regride ao eu como suporte à condição sofrente. A famosa assertiva de Wilhelm Buck de que toda alma se encontra aprisionada na estreita cavidade do molar (no caso da dor de dente) foi magistralmente utilizada por Freud para ilustrar esse fenômeno.

Gabbay (1999) retoma o pensamento de Ferenczi (1926) acerca deste texto freudiano para afirmar que, também nos casos de envelhecimento, esse desinvestimento libidinal é algo recorrente e pode ser explicado pela mesma lógica do narcisismo. Uma vez que a libido agora se encontra escassa e o sujeito necessita de um mínimo de investimento narcísico para sobreviver, ele retira parte, ou toda libido do mundo externo nos casos mais graves, e passa a se interessar cada vez mais por suas memórias, suas fantasias e suas próprias dores, que usualmente são várias e frequentes.

Segundo a autora, alguns fenômenos típicos dessa fase, como o retraimento de interesses, certo egoísmo e a despreocupação com os fenômenos ao seu redor são confirmações desse remanejamento libidinal para o próprio eu (Gabbay, 1999). Importante frisar que estas não são características dominantes em todas as pessoas de idade avançada. 
Observando a nova organização libidinal da velhice, que tanto se assemelha a primeira de nossas vidas, aquela do narcisismo primário, podemos pensar que os ciclos de desenvolvimento são realmente transitórios e se sucedem. Podemos aventar ainda a possibilidade de estes serem também partes de uma espécie de sistema fechado, onde a última fase do desenvolvimento acena com o reinício da primeira.

Evidente que se pode aplicar o conceito de transitório a todas as coisas e todos os momentos de uma existência. Simples é analisar a transitoriedade da fase infantil ou adolescente, de sorte que outras mais acenam como futuro imediato e automático. No entanto, parece difícil ficar impassível a esse questionamento sobre a finitude da existência, quando ela se aproxima cada vez mais das nossas vistas.

Se a chamada morte social já se anuncia, outros anúncios tão ou mais evidentes sensibilizam o velho nessa nova fase da vida. Quando uma mulher idosa se olha no espelho, o que este lhe devolve é uma imagem ligada a uma deterioração, uma imagem com a qual ela não se identifica. Existe uma discrepância entre a imagem inconsciente do corpo e a imagem refletida, posto que se trata de um sujeito psíquico em constante crescimento e evolução, altamente afetado pela representação de um corpo que se deteriora e pela consciência da finitude (Goldfarb, 1998).

O corpo adoecido, macilento e desvitalizado dos estágios finais da vida é criado imaginariamente pelo sujeito, muitas vezes, antes mesmo de possuí-lo verdadeiramente. Neste sentido, podemos pensar em um retorno ao estágio do espelho lacaniano, quando a criança constrói seu corpo ideal através da imagem especular do alter (Gabbay, 1999). No entanto, a nova construção não aponta para um corpo belo e idealizado para a vida, mas um corpo decrépito e adequado para a morte (Messy, 1992).

O corpo, na velhice, é o lugar privilegiado de desilusão narcísica, prometido à decadência e à morte e palco do adoecer, empurrando o sujeito a enfrentar o desafio de manter a aposta na vida. Embora o narcisismo não se afigure como uma defesa contra a pulsão de morte, o papel da ilusão para lidar com as "asperezas da vida" é inegável.

Freud (1915/2000) já nos avisara que a exigência de imortalidade, por ser tão obviamente um produto dos nossos desejos, não pode reivindicar seu direito à realidade. Todos nós padecemos do medo da perda dos nossos objetos de 
investimento afetivo. E a vida em si é alimentada por um constante gerenciamento das nossas porções de afeto, interesse, amor e tempo — sim, o tempo se tornou um capital na economia moderna. As consequências mais comuns no ser humano do "medo de perder algo valioso" são a antecipação defensiva e a culpa. Sempre que estamos excessivamente felizes ou em momentos importantes de nossa existência, esses mecanismos entram em ação nos informando que a felicidade ou estabilidade a qual nos encontramos pode acabar subitamente; são transitórios.

A perda relaciona-se em última análise com o receio da morte. Ou seja, a perda da existência. $\mathrm{O}$ homem primitivo aprendeu a admitir a morte como fato inalterável, mas não consegue assimilar a sua própria aniquilação. Por essa razão a nossa história guarda uma profusão de mitos e religiões espiritualistas. Nada do pulsional solicita a crença da própria morte (Freud, 1915).

Como aponta Ariès (2003), a morte é um tabu na sociedade moderna e hoje, com as novas e avançadas tecnologias para o corpo, com técnicas para o prolongamento da vida que por sua vez trazem a discussão médica e ética sobre o controle técnico do momento da morte, verificamos que fica cada vez mais complexo lidar com a velhice e com seus imperativos que são, apesar de todos os avanços da ciência, a aproximação com a morte e a decadência física.

Freud (1917/2000) nos ajuda a compreender esse horror à morte, na vertente clínica, ao afirmar que o inconsciente não possui representação alguma do que seria morrer, ou deixar de existir. A ideia da morte remonta às angústias impossíveis de significar que o bebê experimenta nos primeiros meses do seu desenvolvimento. O autor toca no tema também em sua análise das sociedades, ao mostrar que um dos maiores medos do ser humano é ver o seu próprio corpo definhar e lhe trazer a infelicidade e o sofrimento.

A infelicidade humana, segundo Freud (1930/2000), pode advir dos relacionamentos que terminam e deixam um vazio na vida do sujeito, do mundo que apresenta desafios gigantescos para a frágil constituição humana e principalmente do próprio corpo que se encaminha inexoravelmente para a morte. Freud aponta o corpo como uma das fontes do mal-estar humano, sublinhando que "este permanecerá para sempre como uma estrutura passageira, com limitada capacidade de adaptação e realização", mas que este reconhecimento não deveria ter um efeito paralisador na medida em que podemos mitigar este sofrimento, em parte (inclusive com o avanço da ciência), mas nunca totalmente (1930, p. 85). 
Para Berlinck (2000) a envelhescência pode ser definida - enquanto objeto e circunstância psíquica - como um desencontro entre o inconsciente atemporal e o corpo, âmbito da temporalidade, ou por um encontro da alma sem idade com o corpo que envelhece, como apontamos anteriormente. Esse encontro-desencontro constitui uma discrepância com efeitos traumáticos cuja complexidade situa-se no arranjo entre o corpo, a subjetividade e o social, justamente na intersecção desses campos, aprisionando o sujeito por seu corpo, sua estrutura psíquica e por seu lugar no social que é assimilado e atuado pelo velho. Essa crise traumática exige um trabalho psíquico: a envelhescência.

\section{Tempo para envelhecer}

$\mathrm{Na}$ "moderna pedagogia" de atividades para a terceira idade criam-se atividades exclusivas para os velhos que vão da universidade às academias de dança, deixando de lado o fato de que o que vai enriquecer-lhes a vida é exatamente o contato com os mais jovens, os novos amigos, o fazer e trocar experiências distintas. Em seu livro Filosofia do espírito científico Bachelard (1972) aponta a importância do "velho" conhecimento na formulação dos novos. O que significa dizer que a experiência do vivido e dos antigos saberes não pode e não deve ser desprezada. Sem o velho conhecimento não se cria o novo.

Quando falamos do tempo cronológico, ao qual nos referimos como transitório e fugidio, esquecemo-nos do chamado tempo vivencial, que algumas culturas chamam de kairós. Um tempo que se refere à fruição das coisas e pode ser maior ou menor de acordo com o gerenciamento subjetivo que fazemos dele. Tanto na infância quanto na velhice temos um tempo outro para a realização das tarefas diárias. A vida pode ser experienciada sem as exigências sociais da modernidade que quer pressa para tudo.

Aproveitar esse distanciamento que a velhice traz em relação ao cotidiano e suas pressões deve ser algo valioso para os velhos, e não pode ser tido como sinônimo de incapacidade e signo de exclusão. É sabido que a sociedade moderna tende a tratar os velhos com desprezo, devido ao declínio em suas forças e capacidades. No entanto, essa marginalização do velho não parece ocorrer em todas as culturas. Segundo Gebran (1999) as "sociedades ágrafas" valorizam e reverenciam o saber e o fazer daqueles que já acumularam experiência pelos muitos anos vividos permitindo, assim, a continuidade da cultura. Nestas sociedades a 
única maneira de se adquirir o saber, na ausência de qualquer representação escrita (livros, jornais, computadores etc.), é perguntando e escutando o que os mais velhos têm para ensinar.

Para nós do campo psi, perguntar implica questionar e ouvir o que todos têm a dizer: homens ou mulheres, pobres ou ricos, jovens ou velhos. Pensando nestes últimos assinalamos a importância do reconhecimento de histórias de toda uma vida repleta de feitos épicos, trágicos, cômicos em suas múltiplas experiências subjetivas. Diferentes nuances e expressões do pathos (paixão e padecimento) que os guiou ao longo de suas existências. Lembremo-nos que pathos não é apenas sofrimento, mas tudo aquilo que nos constitui, o que nos dá a forma que temos e que nos constitui como sujeitos.

Mais ainda, todos nós psicanalistas reconhecemos em nosso Egum (Freud) o lugar da ancestralidade, de transmissor de um saber que nos foi legado e sobre o qual construímos a nossa existência enquanto profissionais.

\section{Tentando escutar}

Dentro de poucas décadas o número de mortes voltará a superar o de nascimentos em vários países, inclusive o Brasil. E não será por conta dos motivos passados, guerras ou epidemias, mas pela conjugação da mudança de comportamento, que caminha para a redução da natalidade a menos de um filho por mulher, e pelo avanço da medicina, proporcionando longevidade crescente à população dos países desenvolvidos.

Desta maneira, fica muito difícil definir nos dias de hoje quando começa realmente a chamada terceira idade. Uma parte da população do mundo trabalha até perder as forças ou adoecer. Outra se aposenta ainda no vigor das forças chegando, algumas vezes, a adoecer de tédio; amargurados com tudo, infelizes e desapontados com o que julgavam ser um direito de descansar e viver bem (Vilhena, Rosa \& Novaes, 2013).

Servindo-nos do ideário vigente, que afirma a velhice como tempo do descanso, de poucas emoções, do corpo em decadência e, nos tempos atuais, das vidas descartáveis, vale ressaltar que é o olhar que a vê como estrangeira, que a torna mais estranha em seus próprios corpos. É este olhar que cria os interditos que balizam o que supostamente é ou deixa de ser adequado a uma faixa etária. O olhar 
alheio é, não raro, mais cruel que a decadência das formas (Vilhena \& Novaes, 2009).

A ciência e suas fantásticas descobertas no ramo farmacêutico proveem pílulas de longevidade capazes de "tratar" a velhice, como se algo natural precisasse de tratamento. O mercado da indústria anti-aging movimenta hoje US\$ 100 bilhões ao ano, e em 1990 esse setor nem sequer existia na economia mundial (Cabral, 2012).

Para os desconfortos do envelhecimento, a reposição hormonal. Para os sinais da passagem do tempo, as cirurgias e a cosmetologia. A menopausa, vista como algo "natural" é reduzida ao âmbito biológico, com seus sintomas "desagradáveis", facilmente suprimíveis com o tratamento adequado. Para os homens, simplesmente Viagra.

Contudo, acreditamos que o corpo solicita outro discurso que não se restringe às reposições hormonais ou às disfunções eréteis. O que nos parece fundamental em relação ao conceito de saúde, especialmente se tomamos como referência a noção de Sawaia (2006) que coloca a saúde como um princípio ético, é que os profissionais do cuidado não dão relevância aos aspectos psicológicos e emocionais do envelhecimento.

Como aponta Gromann (2007) há um silêncio imposto aos órgãos em sua significação mais profunda - como se estivéssemos diante de um corpo sem narrativa. $\mathrm{O}$ enfermo como subjetividade foi sendo progressivamente excluído e silenciado da cena da enfermidade. Excluído que foi de qualquer implicação no processo de adoecimento.

O que observamos é o total descolamento do sujeito com relação ao sintoma que lhe anuncia e deveria representá-lo. O corpo, tratado apenas como organismo; corpo da ordem da natureza, do qual a medicina se ocupa com grande maestria. $\mathrm{O}$ desejo e o gozo, dois baluartes da concepção do sujeito, estão excluídos do corpo homeostático da clínica médica; neste corpo só se observam dores e afecções com o intuito corretivo e normalizador. Quando deveria ser o inverso, pois o corpo é um lugar de gozo. E o sintoma vem expor uma falta. É nesse momento que deveríamos nos perguntar a respeito do desejo do Outro, "por que" ou “o que ele quer de mim"?

Longe de promover um desaparecimento da angústia, trata-se de tornar possível a resolução de um tipo de angústia paralisante e caminhar em direção a outras angústias vivenciais. $\mathrm{O}$ fundamental nesse contexto é a mudança na relação 
do sujeito com o mundo que o cerca, restabelecendo os nexos psicológicos, fisiológicos e sociais, e eliminando a separação entre pensar, sentir e agir. Saúde é liberdade de movimentos do corpo e da mente, é possibilidade de ter esperanças e potencializá-las na ação.

É esta dimensão que fica perdida quando reduzimos os cuidados com o corpo senil (ou qualquer outro!) a questões como vaidade ou funcionalidade, deixando de lado todos os aspectos subjetivos envolvidos no processo de envelhecimento. É como se desistíssemos do desafio de significar seus corpos de forma diferenciada daquela em que foram pensados até muito recentemente.

Se por um lado a cultura impõe de forma radical uma estética onde não há lugar para a velhice e um desempenho que é incompatível com o envelhecer, é preciso estar atento àquilo que retira do sujeito a sua implicação em seu sintoma, em seu pathos, que dificilmente será transformado em questão, posto que será reduzido a uma intervenção cirúrgica, uma medicação adequada, um tratamento rejuvenescedor ou a internação em um asilo.

Da mesma maneira que uma imagem não se reduz a uma etapa, não podemos reduzir o envelhecimento à velhice. O envelhecimento é um processo irreversível, que se inscreve no tempo. Começa com o nascimento e progride inexoravelmente até a destruição do indivíduo (Messy, 1992).

Partimos do pressuposto que os ciclos biológicos seriam momentos em que haveria uma rearticulação das marcas sensoriais, constitutivas das imagens corporais (Dolto, 1984; Dolto \& Nasio, 1991) que servem de base para o eu. Nesse momento, o corpo portaria sensações que poderiam permitir pensar sua condição de forma muito distinta, desde que narrativas possam ser construídas.

\section{Considerações finais}

Nos dias de hoje, não podemos sustentar que a subjetividade se processe de forma tão desgastante, a ponto de produzir rigidez e imutabilidade, exaurindo o movimento pulsional (Millot, 1988). Os sujeitos contemporâneos se constituem num universo caracterizado pela aceleração de mudanças que não mais asseguram uma estabilidade identitária (Kristeva, 1993). O próprio Freud, desde a segunda tópica, demarcou o caráter inesgotável da insistência pulsional, e é disso que tratamos quando nos dedicamos a desvelar os labirintos do desejo humano, que se apresenta encarnado num corpo sexuado. 
A velhice deve ser considerada como um fenômeno biológico com profundas consequências psicológicas. Exatamente por ter uma dimensão existencial que modifica a relação da pessoa com o tempo, o mundo e com sua própria história. Disso já nos falava Freud que aos setenta anos e em luta com sua prótese no maxilar, que lhe consumia uma "energia preciosa", dizia ainda preferir a existência à extinção.

É fundamental frisar também que "velhice" não é diagnóstico. Muito menos insígnia clínica que demande qualquer intervenção psicanalítica. Também é verdade que não existe a necessidade real de se ter um "problema" para que exista demanda de análise. Que o diga uma paciente nossa, quando afirma que "análise não é algo que a gente precisa, é algo que a gente merece".

$\mathrm{O}$ efeito do discurso vigente - modulado pela lógica social do tempo útil que objetos, utensílios eletrônicos e pessoas devem ter, como se tudo tivesse um prazo de validade mais curto na sociedade moderna - tem profundo impacto na economia psíquica dos pacientes velhos, ao ponto dos mesmos afirmarem estar sofrendo de velhice. $\mathrm{O}$ termo velhice assume valor de significante, redefinindo a forma de o sujeito conceber a si mesmo e ao seu próprio sofrimento.

Em psicanálise acredita-se que o sujeito se apropria de sua doença sempre de forma peculiar, e só a análise da narrativa particular daquele sujeito é capaz de deslindar os meandros de seu sintoma. Em tempos de patologização da normalidade, o fenômeno biológico do amadurecimento ganha status de doença e promove efeitos sintomáticos particularizados nos velhos. Daí a necessidade, mais uma vez, de se colocar em palavras estes efeitos com o objetivo de desconstruir ou reelaborar as angústias e dores advindas da condição de estar velho.

A profusão de enunciados pedagógicos, no campo das práticas, que objetivariam uma melhor adaptação às chamadas perdas da velhice, acabam por ressaltá-las. Aprisionado em categorias e em ideais, retira-se do sujeito sua singularidade tornando seu caminho uma estrada de mão única, onde o desejo não mais comparece. Aos velhos doentes, cansados, em sofrimento, a diferença é calada e reduzida à explanação: "é da velhice", ou "são os desconfortos da melhor idade...".

A singularidade da dor (física ou psíquica) como experiência subjetiva, torna-a um campo privilegiado para pensarmos a relação entre o indivíduo e a sociedade. Toda experiência individual inscreve-se num campo de significações 
coletivamente elaborado; se até isto lhe é negado o que dizer desta existência? Como resposta a esta e muitas outras questões que o texto levanta, propusemo-nos a falar da velhice naquilo que ela tem de mais precioso, ou seja, a oportunidade de existir, ainda que caracterizada como estágio final desta mesma existência. Daí termos resgatado o conceito de envelhescência; mais do que um puro significante, a envelhescência é um ato de subjetivação (Berlinck, 2000).

Em um mundo cada vez mais complexo, onde a economia de trocas simbólicas, apoiada nas novas tecnologias, esmaece o conceito de fronteiras e territórios (Turkle, 1985), também os suportes identitários se transformam. Temos de repensar os limites do corpo e da anatomia na constituição das subjetividades, situando a velhice em meio a esta revolução, que inflete significativamente sobre os saberes médico e psicológico.

\section{Referências}

Ariès, P. (2003). História da morte no Ocidente. Rio de Janeiro: Ediouro.

Bachelard, G. (1972). Filosofia do novo espírito científico. Lisboa: Ed. Presença.

Baudrillard, J. (1997). A troca simbólica e a morte. São Paulo: Loyola.

Berlinck, M. T. (2000). Psicopatologia Fundamental. São Paulo: Escuta.

Cabral, M. (2012). Ganhos e perdas. Rev. Página 22, Ed. 70. Recuperado em 20 abril de 2013 de <http://pagina22.com.br/index.php/2012/12/ganhas-eperdas/>.

Dolto, F. (1984). Sexualidade feminina. Libido, erotismo, frigidez. São Paulo: Martins Fontes.

Dolto, F. \& Nasio, J. D. (1991). A criança do espelho. Porto Alegre: Artes Médicas.

Ferenczi, S. (1926). Contraindicações da técnica ativa. In Obras completas III. São Paulo: Martins Fontes.

Freud, S. (2000). Sobre o narcisismo: uma introdução. In Edição Eletrônica Brasileira das Obras Psicológicas Completas de Sigmund Freud (Vol. 14). Rio de Janeiro: Imago. (Trabalho original publicado em 1914).

Freud, S. (2000). Sobre a transitoriedade. In Edição Eletrônica Brasileira das Obras Psicológicas Completas de Sigmund Freud (Vol. 14). Rio de Janeiro: Imago. (Trabalho original publicado em 1915). 
Freud, S. (2000). Luto e melancolia. In Edição Eletrônica Brasileira das Obras Psicológicas Completas de Sigmund Freud (Vol. 14). Rio de Janeiro: Imago. (Trabalho original publicado em 1917).

Freud, S. (2000). O mal-estar na civilização. In Edição Eletrônica Brasileira das Obras Psicológicas Completas de Sigmund Freud (Vol. 21). Rio de Janeiro: Imago. (Trabalho original publicado em 1930).

Gabbay, R. (1999). Considerações sobre psicanálise com idosos. Anais da Primeira Jornada de Psicanálise com Idosos e suas Interseções, Rio de Janeiro: EBP, 31-39.

Gebran, P. (1999). Velhos nas sociedades ágrafas. Anais da Primeira Jornada de Psicanálise com Idosos e suas Interseções, Rio de Janeiro: EBP, 20-30.

Geertz, C. (1996). Representações simbólicas. Rio de Janeiro: Zahar.

Goldfarb, D. C. (1998). Corpo, tempo e envelhecimento. São Paulo: Casa do Psicólogo.

Gromann, R. M. G. (2007). A política do erotismo na maturidade feminina: um estudo sobre as relações entre os estados hipocondríacos e melancólicos.

Kristeva, J. (1993). Les Nouvelles Maladies de L’Âme. Paris: Fayard.

Messy, J. (1992). A pessoa idosa não existe. São Paulo: Aleph.

Millot, C. (1988). Nobodaddy, a histeria no século. Rio de Janeiro: Jorge Zahar.

Sawaia, B. B. (2006). Dimensão ético-afetiva do adoecer da classe trabalhadora. In S. T. M. Lane \& B. B. Sawaia (Orgs.). Novas veredas da psicologia social (pp. 157-168). São Paulo: Brasiliense.

Turkle, S. (1985). The Second Self: Computers and the Human Spirit. New York: Simon \& Schuster, Inc.

Vilhena, J. \& Novaes, J. V. (2009). Un corps à la recherche d'un logement. Corps, violence et médecin. In C. Masson \& C. Desprat-Pequignot (Orgs.) Le corps contemporain: créations et faits de culture (pp. 113-136). Paris: L'Harmatan.

Vilhena, J. (2012). Repensando a velhice em tempos sombrios. In R. Pocinho \& E. Santos (Orgs.). Envelhecer em tempos de crise: respostas sociais (pp. 11-28). Coimbra: Legis Editora.

Vilhena, J. et al. (2013). Para além dos anos vividos. Uma leitura das categorias clínico discursivas acerca da velhice. In R. Pocinho \& E. Santos (Orgs.). Envelhecer hoje, conceitos e práticas (pp. 151-175). Curitiba: Appris. 


\section{Resumos}

(The shadow of a body that presents itself: body image and aging)

Old age has facets and preconceptions that are associated with what it represents. Our aim here is to study the peculiarities related to the phenomenon of being old and its impacts on the subject. We focus on how individuals deal with the disparity between the timeless unconscious and the aged body. We assume that the discourses that standardize the body dominate the symbolic subjective life of the subject and leave no room for the construction of an individual narrative.

Key words: Ageing, body, death, psychoanalysis

(L'ombre d'un corps qui s'annonce: corps, image et vieillir)

La vieillesse possède de nombreuses facettes et de préjugés associés à ce qu'elle représente. Notre article porte sur l'étude des particularités liées au phénomène d'être âgé et de ses impacts sur le sujet, en soulignant comment le décalage entre l'inconscient intemporel et le corps âgé, aussi appelé vieillir, est géré. Nous supposons que les discours qui normalisent le corps dominent la vie symbolique subjective du sujet, ne laissant aucun espace pour la construction d'un récit individuel.

Mots clés: Vieillir, corps, mort, psychanalyse

(Bajo la sombra de un cuerpo que se anuncia: cuerpo, imagen y envejecimiento)

La vejez tiene muchos aspectos y prejuicios asociados a lo que representa. Nuestro objetivo es estudiar lo que es peculiar acerca del fenómeno de 'ser viejo' y sus impactos en el sujeto, destacando el manejo del desacuerdo entre el inconsciente atemporal y el cuerpo envejecido, a que se refiere el envejecimiento. Partimos del supuesto de que los discursos que regulan el cuerpo dominan la vida simbólica y subjetiva del sujeto sin dejar espacio para la construcción de una narrativa individual.

Palabras claves: Envejecimiento, cuerpo, muerte, psicoanálisis

(Der Schatten eines Körpers, der sich ankündigt: Körper, Image und Altern) 
Das Alter hat verschiedene Facetten und ist mit Vorurteilen belastet bezüglich dessen, was es darstellt. Unser Ziel ist es, die Besonderheiten in Zusammenhang mit dem Phänomen des alt Seins und seinen Auswirkungen auf das Individuum zu untersuchen, wobei wir hervorheben, wie mit der Diskrepanz zwischen dem zeitlosen Unbewussten und dem gealterten Körper - auch das Altern genannt - umgegangen wird. Wir gehen davon aus, dass die Ansätze, die den Körper in Normen fassen, das symbolischsubjektive Leben des Subjekts bestimmen und folglich kein Raum zur Entwicklung einer individuellen Gestaltung bleibt.

Schlüsselwörter: Altern, Körper, Tod, Psychoanalyse

Citação/Citation: Vilhena, J. de, Novaes, J. de V., \& Rosa, C. M. (2014, junho). A sombra de um corpo que se anuncia: corpo, imagem e envelhecimento. Revista Latinoamericana de Psicopatologia Fundamental, 17(2), 251-264.

Editor do artigo/Editor: Prof. Dr. Manoel Tosta Berlinck 


\title{
Segundo Artigo - Envelhecimento e seus possíveis destinos. Uma reflexão acerca do trabalho do negativo
}

Artigo aceito para publicação na Revista do Tempo Psicanalítico, 47(1), jun. 2015. Autores: Carlos Mendes Rosa, Junia Vilhena

Recebido em: 17/08/2014

Aceito em: 24/03/2015

As referências bibliográficas foram mantidas no formato original da revista.

\section{Resumo}

O presente texto investiga as operações de desinvestimento libidinal postas em cena pela pulsão de morte na realidade do envelhecimento masculino. Fazemos um recorte do conceito de pulsão de morte na psicanálise e apresentamos o trabalho do negativo de André Green, referenciado no complexo da mãe morta, como possível forma de simbolização das frustrações e perdas ocasionadas pelo envelhecimento. Apontamos ainda o lugar da palavra como fundamental na articulação do sujeito com sua própria condição.

Palavras-chave: Envelhecimento, trabalho do negativo, pulsão de morte

Aging and its possible destinies. Reflections on the role of Green's "negative work".

\begin{abstract}
This paper investigates the operations of libidinal disinvestment put into play by the death drive in the reality of the aging male. We point out the concept of the death instinct in psychoanalysis and present Geen'stheory on the work of the negative, emphasizing the dead mother complex as a possible form of symbolization of frustration and loss caused by aging. We also point the place of the word as the basic articulation of the subject with his own condition.
\end{abstract}

Keywords: Aging, work of the negative, the death drive 


\begin{abstract}
Chega um momento em que somos aves na noite, pura plumagem, dormindo de pé, com a cabeça encolhida. O que tanto zelamos na fileira dos dias, o que tanto brigamos para guardar, de repente não presta mais: jornais, retratos, poemas, posteridade. Minha bagagem é a roupa do corpo...
\end{abstract}

Fabricio Carpinejar

\title{
INTRODUÇÃO
}

Se são recorrentes as ideias sobre sentimentos de tristeza no envelhecer, não podemos deixar de assinalar que em nossa cultura todos os esforços caminham no sentido não de vivenciar e compreender a tristeza, mas sim de ocultá-la, negá-la ou disfarçá-la. Tais sentimentos, decorrentes de mutações de ciclos próprios da vida, não são, obrigatoriamente, patológicos e, neste sentido, nem sempre estar triste é estar deprimido.

Acreditamos que uma das questões fundamentais ao tratarmos do tema do envelhecimento deve ser a representação simbólica da velhice e suas implicações subjetivas posto que já não mais vivemos em sociedades onde a velhice é encarada como sabedoria, prestígio e experiência.

É fundamental frisar que "velhice" não é diagnóstico. Muito menos insígnia clínica que demande qualquer intervenção terapêutica. Mas parece ser uma questão, frequente nos velhos que procuram atendimento clínico, a queixa de estarem "sofrendo de velhice", - um corpo faltoso e decrépito ou como já cantava Djavan na década de 80, - "uma agonia decorrente de uma briga que dura horas a fio, um corpo que fica faltando um pedaço, que nem a lua minguando".

Entender como o envelhecimento tem sido vivido por homens, do ponto de vista das possíveis limitações e dificuldades que isso pode acarretar nos relacionamentos, nas atividades exercidas em sua capacidade de existir prazerosamente, é contribuir para a compreensão e intervenção no atendimento de uma parcela significativa da sociedade atual.

Sabemos da irreversibilidade do envelhecimento biológico, estreitamente vinculado à também irreversível finitude da vida, acarretando a lentidão dos movimentos físicos, a perda de memória recente, a diminuição da capacidade orgânica de recuperação celular e tantos outros fatores que levaram a sociedade, ao 
verificar tais diferenças, a propor uma separação social dos indivíduos (Vilhena et al, 2013).

Associada a essa tendência, existe outra, de o homem não aceitar o envelhecimento, já que envelhecer evoca também a ideia de finitude. No entanto, o desejo de não envelhecer, que tem sido estudado em diferentes culturas, reflete um desejo atávico de o homem manter-se jovem ou imortal.

Freud (1915) quando fala da atitude que adotamos em relação à morte, escreve: "Tentamos silenciá-la na realidade e dispomos até mesmo de um provérbio que diz 'pensar em alguma coisa como se fosse a morte'." Prosseguindo, diz

"é impossível imaginar nossa própria morte e, sempre que tentamos fazê-lo, podemos perceber que ainda estamos presentes como espectadores. Por isso, a psicanálise pôde aventurar-se a afirmar que no fundo ninguém crê em sua própria morte, (...) no inconsciente cada um de nós está convencido de sua própria imortalidade". (p. 327),

O que fazer? Como lidar com o inexorável da morte? Buscamos, neste trabalho, propor uma nova ótica acerca de um modo de funcionamento que pode vir a operar no homem velho; trata-se da operação negativizante colocada em cena pela pulsão de morte, ou o chamado trabalho do negativo.

Em nosso percurso nos apoiaremos nos autores do campo da psicanálise como Freud, Lacan e André Green, ilustrando nosso trabalho com alguns exemplos do que nos falam os poetas e escritores sobre o tema.

\section{SOBRE O ENVELHECER}

É próprio do sujeito ter dificuldades em lidar com o tempo em várias etapas da sua vida, mas ela se evidencia de maneira diferente na velhice. O corpo, na velhice, é o lugar privilegiado de desilusão narcísica, prometido à decadência e à morte e palco do adoecer, empurra o sujeito a enfrentar o desafio de manter a aposta na vida. José Gil, filósofo português, refere-se ao corpo enquanto uma “infralíngua" em comunicação com o mundo (Gil, 1997).

Quando prevalece a noção de que o envelhecimento se opõe à vida, o homem tende a se isolar. Como ressalta Elias (1992), o envelhecimento pode gerar uma situação na qual o homem se torne "menos sociável e seus sentimentos menos calorosos, sem que se extinga sua necessidade dos outros" (p. 17). 
A imagem de si, enquanto visão ou concepção que o indivíduo tem de si mesmo, resulta de um processo que envolve as experiências, as impressões e os sentimentos que o indivíduo vivenciou ao longo de sua existência. A maneira como cada um irá reagir ao envelhecimento não deixa de estar relacionada com as primeiras experiências de infância, que serviram de espelho estruturante e com o qual foram constituídos os alicerces da subjetividade.

Na clínica, frequentemente, escutamos de homens que por não aceitarem o envelhecimento e, envergonhando-se de sua atual condição, evitam o espelho que o olhar do outro, imaginariamente, lhes devolve. Assim, por não poderem elaborar as perdas com que se defrontam, correm o risco de também evitar a vida, saindo de cena, retirando-se da vida ainda em vida (Perez, 2004).

Bauman (1998) destaca que uma das características do mundo atual é a tendência ao isolamento, ao individualismo, à solidão e à privatização da vida humana. Simone de Beauvoir (1990) diz que a velhice é sempre do outro, pois o sujeito não a imagina em si mesmo. Para a autora, o velho dificilmente se vê como tal, e o jovem ignora a velhice que já reside em seu corpo.

Extenso estudo bibliográfico realizado em seu livro $A$ Velhice leva a autora a considerar que os velhos nas sociedades primitivas encarnam a categoria de Outro do social, portando toda ambivalência característica a este conceito. Ou bem o velho é reconhecido como uma espécie de super-homem, ou tratado como uma subespécie da raça. Ele sempre está além ou aquém da condição normal dos demais homens. Esse cenário cria diversas situações martirizantes para aqueles que viveram mais anos do que o aceitável pela sua própria comunidade. Muitas vezes são mortos no auge das forças para manter o poder da tribo que representam, outras são abandonados à mingua para morrerem (Beauvoir, 1990).

Situações dessa natureza também são descritas por Durkheim em seu livro sobre o suicídio. Em várias comunidades, especialmente no antigo mundo viking, os velhos que não podem mais lutar pela sua própria segurança ou dos mais novos, lançam-se do topo de um penhasco com sua armadura de guerra esperando adentrarem orgulhosamente o Valhala. Em outros povos os anciões são voluntariamente enterrados vivos por seu povo como forma de continuidade daquele povo (Durkheim, 1977).

Outra questão fundamental nessas sociedades primitivas, que será amplamente retomada pelas modernas organizações sociais, é o fato do estatuto da 
velhice ser outorgado pela comunidade. Seu status social e subjetivo pouco ou nada depende de suas próprias capacidades, sendo determinado pelos ideais e objetivos da sociedade na qual se encontra inserido (Beauvoir, 1990).

As sociedades atuais também conferem determinados estatutos aos velhos, podendo trata-los com tanta crueldade ou indiferença quanto os povos antigos. Deferência e exaltação do velho são pouco vistos atualmente. Entretanto, atentando para a lógica da felicidade, muitas vezes preferem simplesmente ignorar o processo do envelhecimento tratando-o como indecente ou, fato mais contemporâneo, relativizando suas consequências com rótulos atenuantes e maquiadores, como "melhor idade".

Clarice Lispector refletiu acerca disso quando definiu a velhice como

"...a harmonia secreta da desarmonia: quero não o que está feito mas o que tortuosamente ainda se faz. Minhas desequilibradas palavras são o luxo de meu silêncio. Escrevo por acrobáticas aéreas piruetas - escrevo por profundamente querer falar. Embora escrever só esteja me dando a grande medida do silêncio." (Lispector, 1994, p.16)

Este silêncio muitas vezes se torna ensurdecedor na experimentação do envelhecimento. Ele é o destino irremediável do homem. Experimentar a finitude humana no corpo é algo único frente ao interdito do contemporâneo que prega a impossibilidade da vivência do envelhecimento com a cultura de valores relativos à juventude. Ao mesmo tempo em que o mundo moderno promete a eternidade $\mathrm{e}$ alonga o chronos da vida, ele não lhe reserva um campo de possibilidades (Correa, 2009).

Norbert Elias (1992) comenta os modos pelos quais se instalam os sentimentos de constrangimento, medo e embaraço em relação a tudo que lembre a finitude da vida biológica; dando especial relevo ao isolamento dos velhos e moribundos em asilos, hospitais e clínicas de saúde. Segundo o autor o abandono e isolamento dos velhos em nossa sociedade não podem ser explicados unicamente a partir da ideia de que velho é improdutivo economicamente.

É preciso, então, considerar os aspectos emocionais que interferem neste abandono, compreendendo o que Elias (1992) chama de autoimagem, ou seja, a maneira como as pessoas se veem e se percebem nas modernas sociedades 
industrializadas e urbanas e que não inclui a ideia do envelhecimento e da morte. De fato, não é a própria morte que desperta temor, mas a imagem antecipada da morte na consciência dos vivos. Podemos pensar até mesmo que os moribundos, afastados da cena social, como forma de diminuir o constrangimento dos normais, podem se sentir embaraçados com seu estado e posição. Buscando o isolamento devido à proximidade da morte e o embaraço que esta causa.

O próprio Norbert Elias confessa sentir-se desconfortável em relação à imagem corporal que apresenta para as pessoas, mesmo seu corpo possuindo forças para as tarefas as quais é chamado a realizar.

Sinto-me um equilibrista, familiarizado com os riscos de seu modo de vida e razoavelmente certo de que alcançará a escada na outra ponta da corda, voltando tranquilamente a seu devido tempo. Mas as pessoas que assistem a isso de baixo sabem que ele pode cair a qualquer momento e o contemplam excitadas e um tanto assustadas (p.81).

Ousamos pensar que mesmo nos casos mais afortunados onde se consegue manter uma libido que se evolve e instiga o sujeito velho a novas fronteiras relacionais, com o passar do tempo, esta tende a uma progressiva diminuição quantitativa. Mas aqui não falamos apenas de fisiologia. A libido freudiana tem reverberações distintas em campos vastos da subjetividade. Fala de algo da ordem do biológico, e refere-se também ao campo do simbólico representado pela demanda de amor.

Lacan (1958) comenta que a demanda é algo que nasce da necessidade biológica, entretanto não se contenta com as satisfações que o nível biológico pode oferecer, subvertendo essa última. Ao se criar, a demanda torna-se algo tão preponderante e abrangente que se infiltra na necessidade modificando o seu próprio estatuto original. Estes arranjos libidinais da velhice podem ser melhor compreendidos através da lógica freudiana dos estados narcísicos.

Freud (1914) afirmava que em alguns casos de doença orgânica ou mesmo estados anímicos mais depressivos a libido direcionada para o mundo externo regride ao eu como suporte à sua atual condição de sofrimento. À medida que o sujeito envelhece, notamos que este costuma apresentar um progressivo desinvestimento libidinal das coisas do mundo com consequente investimento no 
próprio sujeito. Alguns fenômenos típicos da velhice como o retraimento de interesses, certo egoísmo e a despreocupação com os fenômenos ao seu redor são confirmações desse remanejamento libidinal para o próprio eu (Gabbay, 1999).

Importante frisar que estas não são características dominantes em todas as pessoas de idade avançada. Não obstante, tentaremos aqui traçar um paralelo entre esse desinvestimento objetal, com consequente retorno ao investimento narcísico, e o trabalho do negativo, especialmente no tocante à função desobjetalizante da pulsão.

\section{DAS PULSÕES DE MORTE}

Freud tenta delinear o mecanismo de construção da memória, como sendo produto de sinapses neuronais que criam caminhos na trama cerebral e deixam facilitações que servirão às próximas organizações psíquicas (Freud, 1895). GarciaRoza (2001) analisa que essas trilhas (ou facilitações) são passíveis de reordenamento de acordo com novos contextos e nexos lógicos (conscientes ou inconscientes) que reordenam as marcas mnêmicas do aparelho psíquico. O que caracteriza a memória é a diminuição das resistências oferecidas por certas barreiras de contato que tendem a facilitar o percurso psíquico em determinada direção e não em outra. A memória, na visão freudiana, passa a ser constituída de mensagens que não estão diretamente vinculadas à experiência, mas trabalham regularmente numa sucessão de sinais, circulando segundo o princípio do prazer.

Uma das grandes interrogações de Freud no Projeto (1985) trata da existência de um sistema (que ele denominou de $\boldsymbol{\omega}$ ) responsável pela qualidade da percepção das coisas no mundo, e consequentemente da memória. Este sistema tem uma particularidade que intriga o médico de Viena, qual seja trabalhar com um mínimo de investimento ou até mesmo sem que nenhum investimento seja feito sobre ele. O sistema $\omega$ é consciente e pode ser excitado através dos estímulos perceptuais captados pelos órgãos sensoriais produzindo diversas qualidades que ele chama de sensações conscientes. O caráter qualitativo será responsável pela distinção entre libido e outro tipo de energia que possa servir de suporte aos processos psíquicos, mais tarde essa energia não-sexual será chamada de pulsão de morte. Uma pulsão de auto conservação que se coloca em oposição às pulsões sexuais.

Ao definir o problema econômico do masoquismo, o fundador da psicanálise aponta inequivocamente o próprio eu como alvo da pulsão de morte, num retorno 
narcísico cuja finalidade é claramente a morte, mas também pode ser interpretado como preservação do próprio sujeito (Freud, 1924). Lacan (1954) afirma a existência desse princípio que leva a libido de volta à morte, entretanto não de qualquer maneira, somente pelos caminhos da vida é que tal princípio irá atuar. Isso faz toda a diferença. A pulsão que encaminha para a morte através da vida é, segundo pensamos, o protótipo do funcionamento inconsciente do homem que se aproxima da finitude.

Neste mesmo seminário Lacan (1954) define a pulsão de morte como atrelada à ordem do simbólico, pois esta, ao mesmo tempo não sendo e insistindo para ser, é aquilo a que visa Freud quando fala da pulsão de morte como o que há de mais fundamental, ou seja, uma espécie de "ordem simbólica em pleno parto, vindo, insistindo para ser realizada" (p. 407).

Nos parece importante apontar aqui que a dimensão da linguagem sofre mudanças na velhice se pensarmos em um âmbito social, especialmente quando nos referimos aos novos nomes com os quais o envelhecimento se traveste no mundo contemporâneo (Vilhena, Novaes \& Rosa, 2014). Ainda assim nos parece um pouco forçado dizer que ocorrem mudanças significativas na relação do sujeito com sua própria linguagem devido ao fato deste ter envelhecido. Entretanto, é evidente que mudanças acentuadas no campo afetivo se põem em marcha na última fase da vida. Por esta razão, nos apoiamos nas proposições lacanianas da pulsão de morte, mas requisitaremos também, neste trabalho, as considerações teórico-clínicas de André Green, para quem o afeto se inscreve em uma lógica da heterogeneidade que caracteriza e impulsiona o processo de representação pela tensão irredutível entre a força e o sentido, o econômico e o simbólico.

Green irá realizar uma leitura diferente da pulsão de morte, não limitando essa força exclusivamente ao registro pulsional, tampouco reduzindo-a a um "automatismo repetitivo", ou ao biologismo incoerente da tendência de retorno ao inorgânico, forçando uma relação direta entre biológico e psíquico (Urribarri, 2010). A pulsão de morte pode ser compreendida em sua teorização mediante a articulação do intrapsíquico e do intersubjetivo. Nesse sentido propõe a utilização do termo pulsões de destruição, com uma dupla orientação, interna e externa, para substituir o termo freudiano, em sua opinião tão problemático.

Green (2009) entende que a função da pulsão de vida é fazer chegar à categoria de objeto aquilo que não possui nenhuma das qualidades, propriedades ou 
atributos do objeto, desde que uma única característica se mantenha no trabalho psíquico realizado: o investimento significativo. Diz ainda que no fim das contas é o próprio investimento que é objetalizado. Outrossim, a meta da pulsão de morte é realizar ao máximo uma função desobjetalizante através do desligamento das coisas e objetos.

Segundo Urribarri (2010) a concepção de pulsão de morte na obra de André Green será basicamente uma força de desinvestimento, e não força de expulsão, ataque ou agressividade, que são manifestações possíveis, mas secundárias, segundo o entendimento do autor. Esse desinvestimento irá afetar os processos de ligação objetal e os seus componentes (representações, objetos, tramas etc).

Anteriormente Green (1980) já havia lançado o conceito de narcisismo negativo como correspondente ao aparecimento de fenômenos de angústia como a alucinação negativa e o sentimento de vazio, resultantes de um desinvestimento massivo e temporário do objeto primário, corolários da destrutividade da pulsão de morte, liberada pelo enfraquecimento do investimento libidinal erótico, que afeta a estrutura do narcisismo secundário e que deixa marcas no inconsciente sob a forma de "buracos psíquicos que poderão ser preenchidos por reinvestimentos". Aqui lemos uma atualização da angústia de castração primordial em momentos ulteriores da vida. Nas palavras do próprio autor "todas as formas de angústia vêm acompanhadas de destrutividade, a castração também, já que a ferida é produto de uma destruição" (p. 243).

Talvez possamos ligar tais fenômenos de angústia à figura do desamparo [Hilflosigkeit] contemporâneo descrito por Freud (1939), o qual o homem deve enfrentar quando destrói todos os ídolos erigidos para sustentar uma significação final do seu próprio ser e da sua existência. Quando se descobre abandonado pelos deuses (ilusões) que ele próprio criou, o homem velho tem de enfrentar o seu desamparo mais radical, o do lugar vazio do fiador último da história simbólica pessoal e, nos casos mais narcísicos, da humanidade (PEREIRA, 1999).

\section{A "MÃE MORTA" É REAL}

Ao abordar o "Complexo da Mãe Morta" Green (1980) assegura que a problemática narcisista está em primeiro plano nas análises, muito mais que os sintomas neuróticos clássicos, sendo que as exigências do Ideal do $\mathrm{Eu}$ se apresentam consideravelmente significativas e associadas com as demandas do 
Supereu. Para o autor o sentimento de impotência é evidente; seja pela incapacidade de sair de uma situação conflituosa, impotência para amar, para ampliar seus ganhos ou até mesmo para manter certo padrão de vida.

O que Green defende em relação ao estado clínico acima descrito é que podemos associá-lo, muitas vezes, ao que ele chamou de depressão de transferência. Uma revivescência, na vida adulta, de uma depressão infantil cujo traço essencial é sua ocorrência diante da presença de um objeto absorto numa espécie de luto, qual seja, a Mãe Morta, que por uma razão qualquer tenha se deprimido, dando origem a uma ausência que irá marcar de maneira definitiva os investimentos do sujeito.

Como apontou Silvia Zornig (2008), trata-se de um tipo de desinvestimento cuja perda é, mais comumente, experimentada em âmbito narcísico e não edípico, pois ocorre um desinvestimento central do objeto primário materno. O complexo da mãe morta refere-se a uma depressão que tem lugar na presença do objeto, onde a tristeza da mãe e a diminuição de seu interesse pelo seu bebê estão em primeiro plano. Esta indicação enfatiza a sutileza da relação mãe-bebê, que pode funcionar como um referencial de base afetiva ou ser pautada pela vivência de ausência e de vazio.

O exemplo, utilizado no texto greeniano, das fotos do pequeno infante feliz ao lado da mãe e posteriormente abandonado por esta, não deixa de suscitar em nós a analogia com a postura de muitos velhos em relação às fotos de família ou dos amigos, onde a felicidade um dia alcançada agora parece ter sido solapada pelas areias do tempo, deixando pouco mais que uma vaga impressão de existência.

Seria impensável afirmar que tal estado de coisas pode igualmente levar um sujeito a um quadro "depressivo" no sentido daquilo que Green aponta? Não seria factível requerer daquele que experiencia a revivescência da castração, para quem as ilusões pouco significam atualmente, e cuja imagem da mãe (em muitos casos, literalmente morta agora) pode tornar-se ambígua, um nível de elaboração de afetos narcísicos como forma de sobrevivência e defesa contra essa mesma depressão?

Neste ponto entra em cena o conceito fundamental de Green acerca do Trabalho do Negativo, especialmente na sua dimensão estruturante da personalidade, evitando que caiamos em uma investigação acerca dos quadros mais patológicos da clínica dos estados limites, o que claramente foge aos propósitos deste trabalho. 
André Green (2009) define como trabalho do negativo o conjunto de operações psíquicas que têm como protótipo o recalque [Verdrangung] e como variações a negação [Verneinung], a denegação [Verleugnunge] e a foraclusão [Verwerfung]. O trabalho do negativo se estende ao conjunto das instâncias do aparelho psíquico; id, ego e supereu. Entre os dois extremos do recalque bem constituído à radicalidade da foraclusão, o trabalho do negativo pode seguir caminhos intermediários como a clivagem e a denegação. Green (1988) entende ainda que a parte assumida pelo objeto nessa elaboração configura-se como um fator de interferência que entra em jogo na constituição da subjetividade por efeitos fora do comum. Se o objeto é responsável por conter e estimular a pulsão, essa dupla ação só se torna possível a partir de um trabalho do negativo estruturante.

Freud (1925) em seu texto sobre "A negativa" afirma que o pensamento tem a capacidade de apresentar à mente aquilo que foi percebido outrora, reproduzindoa por uma representação sem que o objeto externo deva estar necessariamente presente. É a passagem do princípio do prazer para o princípio da realidade. O momento onde o sujeito percebe que não é importante, somente, que ele possua um atributo "bom" e que o integre ao seu ego, mas que, esse atributo corresponda a uma coisa no mundo externo e que dela possa se apossar quando necessário. Green (1988) comenta ainda que a expulsão do mau permite a criação de um espaço interno no qual o eu, como organização, pode nascer para a instauração de uma ordem fundada no estabelecimento de ligações relacionadas a experiências de satisfação. Essa organização facilita o reconhecimento do objeto em estado separado no espaço do não eu e o seu reencontro.

Nesse sentido, Roussillon (2010) assegura que o trabalho de transformação da experiência primária, através da simbolização, à qual trataremos mais adiante, tem uma dupla função de transformá-la em algo apropriado pelo sujeito, e torná-la perdida para sempre, na medida em que ela transforma o próprio sujeito.

As investigações de André Green sobre o trabalho do negativo o conduziram à clínica do vazio, onde se encontra uma espécie de mistura de desinvestimento, de destrutividade inaceitável e de identificação com um objeto destruído pela separação. Esse desinvestimento objetal nos parece claro em muitos casos de idosos cujo interesse pelo mundo exterior cai drasticamente com a chegada da aposentadoria e com o alijamento do universo do trabalho. 
Tentamos interpor aqui as considerações sobre os estados narcísicos e a dinâmica do envelhecimento, especialmente dos sujeitos do sexo masculino, pois nos parece que a mulher idosa encontra meios mais positivos para lidar com essa nova realidade. A mulher, muitas vezes, continua tendo um lugar subjetivo no lar que administra, além do que, acostumou-se a desempenhar várias funções ao longo da vida.

O sujeito que sofre algum tipo de perda realmente significativa para sua economia libidinal, seja um amor, um ideal, ou uma capacidade, encontra-se obrigado pelo teste de realidade, a um trabalho lento e penoso de desligamento do objeto amado. Freud (1917) escreve que durante este processo o sujeito em luto direciona a maior parte de seus pensamentos (quando não todos eles) para o objeto perdido, com o intuito de mantê-lo próximo de si, ainda que seja só por mais algum tempo, ou seja, a vontade é de parar o tempo no instante antes da perda.

A quebra temporal aqui encontrada também foi brilhantemente descrita por Green (apud Urribarri, 2010) quando comenta que a descarga da repetição tenta produzir o vazio no seio do aparelho psíquico. Nesse sentido, a compulsão de repetição é um assassinato do tempo. Não devemos confundir a repetição mortífera com a ex-sistência da cadeia inconsciente, ou seja, algo externo ao sujeito que insiste pela via da linguagem (Quinet, 2000). Trata-se, antes de mais nada, de uma compulsão a desfazer, inscrita em uma lógica de um "anti-tempo". Aparece aqui como um duplo movimento da impossibilidade de renunciar à satisfação imediata e da tentativa de expulsão das frustrações para fora do espaço psíquico (Urribarri, 2010).

O conceito de compulsão à repetição de Green (2009) estabelece sua condição de aparecimento quando o Eu não se apresenta como capaz de tolerar as frustrações (ou decepções) da realidade externa ou quando este é atravessado por uma intensificação, ainda que temporária, de investimento pulsional.

A libido objetal que tem como caminho natural o mundo externo é revertida para o eu como forma de dar a mesma novo sentido, pela via das novas identificações que se formarão a partir de então. Notamos que trata-se de identificações cuja principal função é desinvestir lembranças e afetos relacionados ao objeto faltante. Como já afirmamos anteriormente, as condições muitas vezes limitadoras do "ser velho", somadas às perdas reais de pessoas, de forças, de saúde, às perdas imaginárias de amor, de tempo, de vida e às perdas simbólicas que falam 
do status subjetivo, dos papéis sociais e do lugar na família, constituem um emaranhado de objetos faltantes dos quais o sujeito terá que se separar psiquicamente, rejeitar a conservação das marcas destas experiências, não sem um cadinho de elaboração, caso possua meios para tanto, e de sofrimento (Rosa, 2014).

O movimento da pulsão de morte tem como objetivo o retorno a um estado de satisfação perdido, desde sempre, há que se dizer, mas cuja sensação deixada tornou-se meta a ser alcançada pelo sujeito. Podemos pensar que na velhice, onde as perdas motoras, afetivas e sociais aparecem tão claramente, almejar essa satisfação com a qual se sonhou a vida inteira nos parece não só uma aspiração justificada, como talvez a única compensação para o atual estado das coisas. Acreditar que tal satisfação requer comumente uma volta a um estado anterior e, diferente da pulsão de vida que precisa de elementos externos para se efetivar, demanda tão somente a entrega ao movimento interno do gozo, insistência da cadeia significante, de retorno ao próprio eu, nos leva a colocar a efetividade da pulsão de morte em lugar privilegiado no organismo envelhecido.

Sobre este movimento de retorno Lacan (1969) irá afirmar claramente que "o que se repete não poderia estar de outro modo, em relação ao que repete, senão em perda" (p. 44). Marca decisivamente o estatuto da repetição como a perda de algo que, segundo suas próprias palavras, pode ser "perda de velocidade, de força...", de vivacidade, de perspectivas e tantas outras, acrescentaríamos nós, por serem tão comuns no envelhecimento. A pulsão de morte é posta em marcha pela presença do objeto perdido.

O trabalho do negativo pode ser entendido como expressão da pulsão de morte, de sorte que sua tarefa consiste nas atividades de negativização, de rompimento, desligamento e desobjetalização. André Green também comenta que para poder dizer sim a si mesmo é preciso poder dizer não ao objeto. Esta dinâmica é fundamental para nosso estudo acerca do envelhecimento. Pois, é através deste ato de dizer não que os limites psíquicos podem se estabelecer, favorecendo a capacidade de representação e a constituição subjetiva (Green, 1988).

Mendes e Garcia (2012) acrescentam que o conceito de trabalho do negativo traz a ideia de que toda negação pode ser estruturante ou patológica dependendo em que condições e em que contexto este "não" se dá. Negar a finitude da existência, distanciar-se do convívio social cada vez mais exigente com um corpo e espírito 
alquebrados, investir em pequenas conquistas e prazeres pessoais parecem formas muito interessante de aplicação do trabalho do negativo.

Podemos pensar na afirmação de Eliane Brum (2008) em sua bela crônica documental Casa de Velhos: "Contaram para todo mundo que eles queriam descansar... Descansar é tudo o que ele não quer. E quem desejaria, com a eternidade espreitando logo ali, na próxima curva?".

As operações negativizantes, colocadas em cena pela pulsão de morte através da função desobjetalizante, não comportam uma dimensão puramente destrutiva, mas são também fundamentais no trabalho do negativo em sua função de estruturar os limites intra e inter-psíquicos. Quando bem sucedidos favorecem processos sofisticados como a construção de representações, a simbolização e a abstração; processos esses que se constituem como fundamentais a uma teoria sobre o pensamento (Garcia e Damous, 2009).

A noção de investimento energético está presente na obra freudiana desde o Projeto. O termo Besetzung designa uma representação cujo afeto não foi desinvestido (ou descatexizado nas traduções correntes para o português). Trata-se de um tipo de energia psíquica que se liga ao soma (nos termos freudianos iniciais, se ligaria a um neurônio) e concomitantemente se liga a uma representação ou um grupo de representações. Essa concepção nos dá a ideia de investimento como uma carga que se coloca ou se retira de algo, no caso de uma representação (Garcia-roza, 2001).

O primeiro investimento energético (Freud depois chamará de pulsional) do eu inaugura a saída do autoerotismo e a especificação das zonas erógenas. A essa fase a psicanálise dá o nome de narcisismo. Em uma leitura greeniana, o narcisismo se destaca como o primeiro alicerce psíquico capaz de resistir aos ataques da pulsão de morte. Paradoxalmente é ao mesmo tempo o agente e o resultado da primeira vitória das pulsões de vida contra a pulsão de morte (Urribarri, 2010). A partir deste estádio da vida o sujeito será capaz de sentir-se olhado pelo outro. Freud (1914) celebra o momento no qual o olhar da mãe não atravessa o sujeito. Reconhecendo a existência de um Outro, o sujeito pode enfim disponibilizar uma quantidade de energia (insistimos no termo arcaico) para ser investida no objeto, modelando assim, de forma inaugural, a libido objetal.

Entretanto, uma considerável quantidade de libido narcísica deverá sempre estar presente para a manutenção da vida psíquica. Além disso, se uma das funções 
do objeto é contribuir para a manutenção de um certo equilíbrio entre as pulsões de vida e morte, os fracassos do lado do objeto podem provocar reações de desequilíbrio que favorecem a expressão das pulsões de destruição (URRIBARRI, 2010). Aliada ao trabalho de preservação das poucas energias restantes na última fase da vida, o trabalho de desinvestimento libidinal, retorno ao narcisismo, pode se configurar com uma possível saída, defesa contra o inevitável.

Segundo Green (2009) o narcisismo primário constitui a "estrutura enquadrante" do psiquismo. A qual será a matriz de sentido que reforça uma dupla dimensão pulsional e identificatória, "concebida como o resultado da interiorização do suporte materno primário, graças aos mecanismos de duplo retorno das pulsões e de alucinação negativa da mãe. Enquadre materno carnal, corporal, constituído no corpo a corpo da relação" (Urribarri, 2010, p. 33).

Pensamos analogamente que a mãe, enquanto lugar de vazio ou espaço potencial interno, seria a moldura que contém qualitativamente a expansão pulsional do eu nascente, numa referência próxima ao conceito de "continente/contido" de Bion (1962). Esta estrutura enquadrante, constituição do ego delimitado pelos contornos da mãe castrada, será a preceptora dos destinos dos processos de percepção, representação e finalmente de simbolização.

Resta dizer ainda que a função objetalizante (besetzung) das pulsões de vida ou de amor, cuja origem remonta à estrutura enquadrante, tem como principal consequência realizar, pela mediação da função sexual, a simbolização. A ausência de simbolização se configura como uma forma de resistência, uma forma de oposição ao processo psíquico.

\section{A CONSTRUÇÃO DE UMA NARRATIVA}

Roussillon (2000) afirma que os debates acerca da simbolização se complicaram entre os principais expoentes da teoria psicanalítica na medida em que se percebeu que nem tudo que o sujeito experimenta como vivência é automaticamente representado ou simbolizado, como Freud chegou a afirmar em alguns pontos da sua obra. Atualmente se compreende que é necessário um certo trabalho psíquico na direção do objeto e sua relação com o sujeito. Mais uma vez entram em questão a qualidade do objeto e o retorno da pulsão.

O autor define que a simbolização leva a uma espécie de representação do processo psíquico que ocorre em três tempos distintos e sucessivos. O primeiro no 
qual a experiência subjetiva é capturada psiquicamente e inscrita, um segundo tempo no qual a experiência é ligada afetivamente e simbolizada enquanto representação coisa, ou seja, neste processo o traço primário é religado à representação coisa. E uma última etapa onde a representação coisa é religada a representação palavra, sendo transferida para o aparelho de linguagem e ganhando um sentido próprio, que se pode dizer único, para o sujeito (Roussillon, 2000).

Na prática podemos observar tal fenômeno ocorrer com idosos quando dizem que "palavras são tudo o que me restam". Quando narram suas histórias para os mais novos, muitas vezes pouco interessados em escutar, como forma de reviver e recuperar um passado perdido. Um exemplo interessante da capacidade da representação palavra para manter o afeto ligado ao traço primário pode ser visto nas diversas oficinas de palavras com idosos, cuja proposta é fazer o idoso falar de seu cotidiano e, paulatinamente, ir se apropriando, através da fala, das suas lembranças, primeiro as recentes, passando pelos eventos anteriores até chegar aos conteúdos infantis de cada participante. Este trabalho, realizado em grupo operativo tem, muitas vezes, a função de preservar a sanidade e a memória do idoso (Rosa, 2014).

Em outro estudo dissemos o quão fundamental é para o nossas pesquisas compreender que os modos elaborados de simbolização podem se dar na ausência do objeto simbolizado, desde que um trabalho de simbolização primário tenha sido efetuado, tendo como condição prévia o encontro do sujeito com o objeto ou algo que possa representa-lo.

No caso específico do envelhecimento faz todo sentido pensar que o velho têm condições de enriquecer o seu mundo interno com representações das coisas que ficaram perdidas ao longo do processo de envelhecimento, simbolizando e historicizando as ausências/faltas, para então poderem reinventar novas formas de ser no mundo, novos lugares subjetivos. É fundamental afirmar que negar aspectos do mundo não quer dizer negar a sua presença no mundo, outrossim recusar-se a aceitar a exigências massacrantes da sociedade atual e poder levar uma vida mais adequada às suas pretensões e condições.

Resta dizer com Roussillon que representar é apresentar de novo, é situar dentro do tempo e da história a experiência subjetiva, permitindo que a experiência emocional não mais atravesse a psique sem estar subjetivamente ligada e religada aos objetos. O processo de representação dá condições para que o sujeito se aproprie 
disso que o constitui e os modos pelos quais transforma aquilo que encontra em seu caminho. Em outras palavras, Roussillon (2000) dirá que o processo de simbolização começa après-coup, quando o sujeito pode dar a si mesmo uma cópia, uma espécie de "apresentação" daquilo que aconteceu em sua própria vida. Ou seja, construir uma narrativa própria de sua história.

Em psicanálise acredita-se que o sujeito se apropria de sua condição sempre de forma peculiar, e só a análise da narrativa particular daquele sujeito é capaz de deslindar os meandros do seu sintoma. De preferência, que esta elaboração ocorra sem cair na noção de estigma ou doença e tampouco sem a tentativa de suavizar uma condição natural, que naturalmente traz mais dificuldades ao sujeito, dandolhe novos nomes que não façam jus a seu status, tal como a nomenclatura "melhor idade".

No atual contexto onde a patologização da normalidade torna-se prática comum, o fenômeno biológico do amadurecimento ganha status de doença e promove efeitos sintomáticos particularizados nos velhos. Daí a necessidade, mais uma vez, de se colocar em palavras estes efeitos com o objetivo de descontruir ou reelaborar as angústias e dores advindas da condição de estar velho (Vilhena et al, 2013).

Longe de promover um desaparecimento da angústia, trata-se de tornar possível a resolução de um tipo de angústia paralisante e caminhar em direção a outras angústias vivenciais, estas desafiadoras. $\mathrm{O}$ fundamental nesse contexto é a mudança na relação do sujeito (idoso, ou não, incluído ou não) com o mundo que o cerca, restabelecendo os nexos psicológicos, fisiológicos e sociais, eliminando a separação entre pensar, sentir e agir.

Nenhum outro animal possui a consciência da morte, daí afirmarmos que reagir à condição de mortal é manter-se pleno de humanidade, posto que a consciência da condição humana é, também, a consciência do envelhecimento e uma natural reação ao mesmo. Esse processo tem uma longa história. E é esta história que precisamos ouvir.

Recorrendo, novamente, aos poetas poderemos concordar com Borges (2012) que nos diz “a velhice é um longo entardecer” ou com Philip Roth (2007) que afirma que "a velhice não é uma batalha, a velhice é um massacre". 


\section{REFERÊNCIAS}

Bauman, Z. (1998) O Mal-estar na Pós-Modernidade. Rio de Janeiro: Jorge Zahar.

Beauvoir, S. (1990) A velhice. Rio de Janeiro: Nova Fronteira.

Bion, W. R. (1962) Learning fromexperience.London: Heinemann.

Borges, J. L. (2012) O livro de areia. São Paulo: Media Fashion, 104 p.

Brum, E. (2008) O olho da rua. Uma repórter em busca da literatura da vida real. São Paulo: Editora Globo..

Correa, M.R. (2009) Cartografias do envelhecimento na contemporaneidade. São Paulo: Cultura acadêmica.

Durkheim, E. (1997) Suicide: a study in sociology. The FreePress.

Elias, N. (1992) A solidão dos Moribundos. Rio de Janeiro, Zahar.

Ehrenberg. A. (1998) La Fatiga de Ser Uno Mismo: Depresión y Sociedad. Buenos Aires: Ediciones Nueva Visión.

Freud, S. (1895) Projeto para uma psicologia científica. In: Edição Standard Brasileira das Obras Psicológicas Completas de Sigmund Freud, vol. I. Rio de Janeiro: Imago, 2000.

Freud, S. (1914) Sobre o Narcisismo: uma introdução. In: Edição Standard Brasileira das Obras Psicológicas Completas de Sigmund Freud, Rio de Janeiro, Imago. Vol. XIV. 2000.

Freud, S. (1917) Luto e melancolia. In: Edição Standard Brasileira das Obras Psicológicas Completas de Sigmund Freud, Rio de Janeiro, Imago. Vol. XIV. 2000.

Freud, S. (1920) Para além do princípio do prazer. In: Edição Standard Brasileira das Obras Psicológicas Completas de Sigmund Freud, Rio de Janeiro, Imago. Vol. XVIII. 2000.

Freud, S. (1924) O problema econômico do masoquismo. In: Edição Standard Brasileira das Obras Psicológicas Completas de Sigmund Freud, Rio de Janeiro, Imago. Vol. XIX. 2000.

Freud, S. (1925) A negativa. In: Edição Standard Brasileira das Obras Psicológicas Completas de Sigmund Freud, Rio de Janeiro, Imago. Vol. XIX. 2000.

Freud, S. (1937) Moisés e o monoteísmo. In: Edição Standard Brasileira das Obras Psicológicas Completas de Sigmund Freud, Rio de Janeiro, Imago. Vol. XXIII. 2000. 
Gabbay, R. (1999) Considerações sobre psicanálise com idosos. Anais da Primeira Jornada de Psicanálise com Idosos e suas Interseções, Rio de Janeiro: Escola Brasileira de Psicanálise Movimento Freudiano.p. 31-39.

Garcia, C. A.; Damous, I. (2009) O silêncio no psiquismo: uma manifestação do trabalho do negativo patológico. Caderno de Psicanálise-CPRJ, Rio de Janeiro, ano 31, n. 22 , p. $105-115$.

Garcia-roza, (2001) L.A. Introdução À Metapsicologia Freudiana 1. São Paulo: Zahar.

Gil, J. (1997) Metamorfoses do corpo. In: Portugal, hoje: o medo de existir. Lisboa,Relógio d'Água.

Green, A. (1980) A mãe morta. In: Narcisismo de vida, narcisismo de morte. São Paulo: Editora Escuta, p.247-282.

Green, A. (1988) Seminário sobre o trabalho do negativo. Anexo 3. In: Green, A. O trabalho do negativo. Porto Alegre: Artmed.

Green, A. (2009) O trabalho do negativo. Porto Alegre: Artmed.

Lacan, J. (1954) O seminário, livro 2: o eu na teoria de Freud e na técnica da psicanálise. Rio de Janeiro: Jorge Zahar Editor.

Lacan, J. (1958) A significação do falo. Escritos. Rio de Janeiro: Nova Fronteira.

Lacan, J. (1969) O seminário, livro 17: o avesso da psicanálise. Rio de Janeiro: Jorge Zahar Editor.

Lispector, C. (1994) Água Viva. $13^{\circ}$ edição. Rio de Janeiro: Francisco Alves.

Mendes, L. C.; Garcia, C. A. (2012) Os destinos do trabalho do negativo nas patologias limítrofes. Psicologia em Revista, Belo Horizonte, v. 18, n. 2, p. $277-$ 292.

Pereira, M.E.C. (1999) Pânico e desamparo. São Paulo: Escuta.

Peres, M. R.S. (2004) O homem e as marcas do tempo. In: Monteiro (org) Dimensões do envelhecer. Rio de Janeiro: Revinter.

Quinet, A. (2000) A descoberta do inconsciente. Do desejo ao sintoma. Rio de Janeiro: Jorge Zahar Editor.

Roth, P. (2007) Homem comum. São Paulo: Cia das Letras.

Rosa, C.M (2014) Silêncio, exclusão e morte: o trabalho do negativo na velhice. Polêm!ca, v. 13, n.1.p. 923-944. 
Roussillon, R. (2010) A capacidade de criar e a exigência de criar. Jornal de Psicanálise, v. 43(79), p. 237-256.

Roussillon, R. Le processus de symbolisationetsesétapes. In: Chouvier, B. (ed), Matière à symbolisation, CH 1027 Lonay, Delachaux et Niestlé, 2000. Disponível em http://psycho.univ-lyon2.fr/sites/psycho/IMG/pdf/doc-226.pdf acessado em 11 de junho de 2013.

Urribarri, F. (2010) André Green: paixão clínica, pensamento complexo. Contemporânea - Psicanálise e Transdisciplinaridade, Porto Alegre, n.10, p. 1143.

Vilhena, J. (2012) Repensando a velhice em tempos sombrios. Pocinho, R., Santos, E. \& Gaspar, J.P., (orgs) Envelhecer em tempos de crise: Respostas Sociais. Coimbra. Legis Editora. p 11-28.

Vilhena, J.; Rosa, C. M.; Novaes, J. V. (2013) Para além dos anos vividos. Uma leitura das categorias clínico-discursivas acerca da velhice. In: Pocinho, R., Santos, E. (orgs) Envelhecer hoje, conceitos e praticas.Curitiba. Ed.Appris. p 151-175.

Vilhena,J.; Novaes, J.V.; Rosa, C.M. (2014) Rev. Latinoam. Psicopat. Fund., São Paulo, 17(2), 251-264, jun.

http://www.fundamentalpsychopathology.org/uploads/files/juniajoanaecarlosjun2 014.pdf

Zornig, S. M. A. (2008) A corporeidade na clínica: algumas observações sobre os primórdios do psiquismo. Rev. do Tempo Psicanalítico, v.40, n.2, p. 327-337. 


\section{Terceiro Artigo - Reflexos do tempo: uma reflexão sobre o envelhecimento nos dias de hoje}

Artigo submetido a Revista Estudos e Pesquisas em Psicologia.

Autores: Carlos Mendes Rosa, Lana Veras, Alysson Assunção

Recebido em: 16/09/2014

Aceito em: em avaliação

As referências bibliográficas foram mantidas no formato original da revista.

\section{Reflexos do tempo: uma reflexão sobre o envelhecimento nos dias de hoje}

\section{Reflexos do tempo: uma reflexão sobre o envelhecimento nos dias de hoje Resumo}

Reflexões sobre a maneira como lidamos com o envelhecimento, com os sinais da passagem do tempo e com a finitude são colocadas em cena neste artigo. A morte, na sociedade ocidental dos tempos atuais, tem sido, frequentemente, tratada com negação e com evitação. De modo que o envelhecer, como sua antessala, é muitas vezes associado a estereótipos de obsolescência, devendo ser evitado ou camuflado. As repercussões do desencontro entre uma subjetividade imortal e um corpo envelhecido podem estar ligadas a vivências de sofrimento que não vêm encontrando amplos espaços de expressão e acolhimento em uma sociedade atravessada pelo imperativo da felicidade, pela espetacularização, pelo culto da performance e pela patologização e medicalização da tristeza. Os autores encontraram - no diálogo com obras artísticas da literatura, da escultura e da fotografia - a possibilidade de pensar alguns dos sentidos do envelhecer e da finitude na contemporaneidade.

Palavras-chave: tempo, envelhecimento, morte, desamparo.

\section{Resumen}


Reflexiones sobre cómo lidiar con el envejecimiento, los signos del paso del tiempo y la noción de finitud se ponen en escena en este artículo. La muerte ha sido tratado con la negación y la evitación en la sociedad occidental moderna. El proceso de envejecimiento, como su antesala, se asocia a menudo con los estereotipos de la obsolescencia, por lo que debe evitarse o escondidos. Las repercusiones de la falta de coincidencia entre una subjetividad inmortal y el cuerpo envejecido pueden estar vinculados a experiencias de sufrimiento que no encuentran un lugar amplio para la expresión y la aceptación en una sociedad atravesada por el imperativo de la felicidad, el espectáculo, el culto de la actuación, la patologización y medicalización de la tristeza. Los autores encontraron - en el diálogo con la literatura, la pintura, la escultura y la fotografía - la oportunidad de pensar en algunos de los sentidos del envejecimiento y la finitud en la actualidad.

Palabras clave: tiempo, envejecimiento, muerte, desamparo.

\begin{abstract}
Reflections on how we deal with aging, the signs of passage of time and the notion of finitude, are put into scene in this article. Death has been treated with denial and avoidance in the modern Western society. The aging process, as his anteroom, is often associated with stereotypes of obsolescence, so that must be avoided or hidden. The repercussions of the mismatch between an immortal subjectivity and the aged body may be linked to experiences of suffering that doesn't find an ample place for expression and acceptance in a society crossed by the imperative of happiness, the spectacle, the cult of performance, the pathologizing and medicalization of sadness. The authors found - in the dialogue with literature, painting, sculpture and photography - the chance to think some of the senses of aging and finitude nowadays.
\end{abstract}

Keywords: time, aging, death, helplessness. 


\section{Reflexos do tempo: uma reflexão sobre o envelhecimento nos dias de hoje.}

Por isso não se deve temer no amor, como na vida habitual, tão somente o futuro, mas também o passado, o qual não se realiza para nós muitas vezes senão depois do futuro, e não falamos apenas do passado que só se revela mais tarde, mas daquele que conservamos há muito tempo em nós e que de repente aprendemos a ler.

Proust.

Reflections: essa foi a palavra que o fotógrafo americano Tom Hussey (2014) escolheu para título de uma sequência de fotos premiadas que realizou em 2010. As imagens capturam o momento em que pessoas envelhecidas se miram em um espelho. No entanto, em lugar de um corpo velho, o que elas veem refletido é uma figura jovem, uma face repleta de frescor e um corpo pleno de potência da juventude (Figura 1).

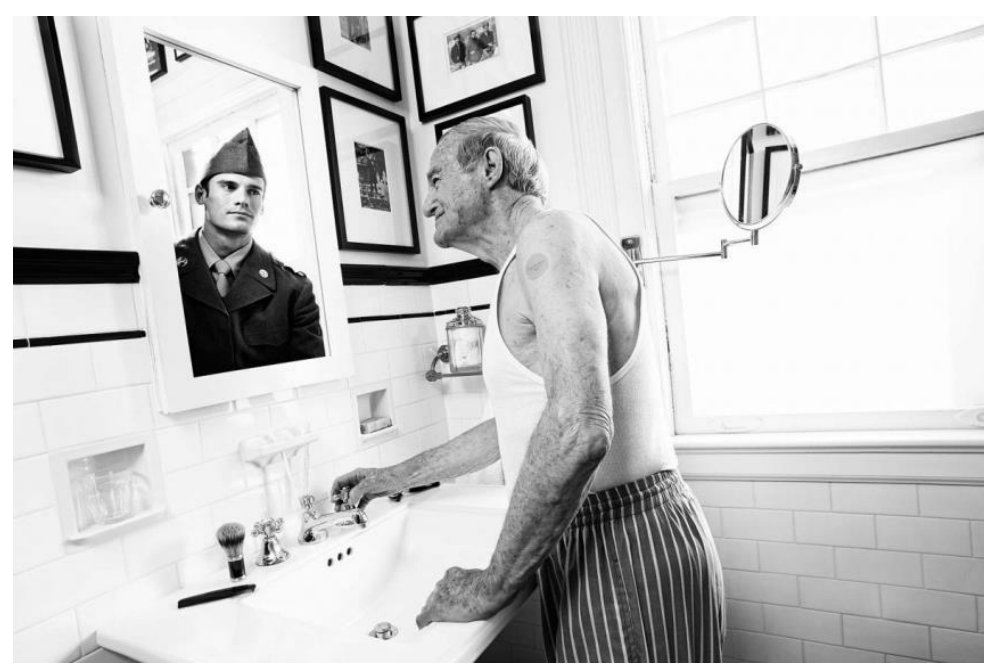

Figura 1 Imagem da série “Reflections” do fotógrafo Tom Hussey. (HUSSEY, 2014)

Hussey afirma ter criado a série após ouvir o relato de um veterano de guerra que não acreditava estar chegando aos 80 anos. Ele dizia se sentir como se tivesse acabado de retornar do combate, contudo olhava para o espelho e via "esse cara velho".

Constatação semelhante à do ex-combatente fez, também, nossa poetisa brasileira Cecília Meireles. Com mais beleza, evidentemente, ela narra seu confrontar-se com o espelho, que a sinaliza a passagem do tempo no seu corpo: 
Eu não tinha este rosto de hoje, assim calmo, assim triste, assim magro, nem estes olhos tão vazios, nem o lábio amargo.

Eu não tinha estas mãos sem força, tão paradas e frias e mortas; eu não tinha este coração que nem se mostra.

Eu não dei por esta mudança, tão simples, tão certa, tão fácil: Em que espelho ficou perdida a minha face? (Meireles, 1958, p. 10)

Podemos pensar a respeito do papel da obra de arte, que capta aquilo nos escapa (a nós que tentamos enxergar a lógica do mundo) e que nos transporta para essa experiência singular que deriva, por sua vez, da singularidade da visão do artista (Silva, 2014).

A tradução do termo_Reflections - título da série de fotografias de Tom Hussey (2014) - para a língua portuguesa admite ao menos duas possibilidades: "reflexos"_e_"reflexões". São justamente os reflexos mostrados no trabalho, incongruentes com os corpos dos sujeitos refletidos, que colocam em cena reflexões sobre a maneira como lidamos com o envelhecimento, com os sinais da passagem do tempo, com a finitude.

Considerando o envelhecimento uma questão inerente à existência humana e merecedora de um olhar compreensivo apresenta-se, aqui, como proposta para este ensaio, a tentativa de compreensão do significado da passagem do tempo para o "estar envelhecendo"._Colocam-se reflexões sobre o envelhecimento, que se torna uma questão problemática quando é entendido como uma inevitabilidade da obsolescência, o que faz com que o indivíduo seja subutilizado e seja destituído de importância social.

\section{A Construção Do Ser Velho}

É pertinente sugerir que a noção de finitude é evocada pelo envelhecer. Por conseguinte, o desejo de não envelhecer reflete um desejo de o homem manter-se jovem, imortal. Com inspiração em Heidegger, podemos dizer que o compreenderse a si mesmo enquanto um constante "poder-ser" é reconhecer-se como o mortal, como um "ser-para-a-morte". A finitude ontológica é a instância balizadora de toda e qualquer possibilidade de estar no mundo, que é onde o ser desempenha as suas atividades e se reconhece como pertencente (Heidegger, 1997)._Só o homem, dentre 
todos os seres vivos, tem consciência da inevitabilidade da morte. Exatamente por essa consciência, durante milênios, a proteção contra o aniquilamento foi a função central dos agrupamentos humanos (Elias, 2001).

O "ser-para-a-morte" é, por sua vez, caracterizado pela angústia, que se manifesta_de forma diferente em cada ser. Para alguns, apresenta-se como inquietação, um incômodo, um não saber o que fazer. Em outros, aparece nos sintomas físicos e psíquicos como, por exemplo, a depressão. Para outros, até mais comumente,_a forma de encarar tal angústia é a negação: pensamos que jamais envelheceremos e, então, nos recusamos a perceber, nos detalhes, as transformações corporais.

É importante destacar que o envelhecimento costuma aparecer mais claramente para os outros do que para o próprio sujeito; ele é um novo estado de equilíbrio biológico: se a adaptação se opera sem choques, o indivíduo que envelhece não percebe._Enquanto envelhecemos, nossas montagens, estratégias e hábitos permitem amenizar durante muito tempo as deficiências psicomotoras (Beauvoir, 1990). Esta surpresa causada no sujeito, ao se encontrar com a imagem envelhecida que o espelho lhe devolve, tão diferente daquela que o inconsciente, que é atemporal, tende a conservar, foi capturada e transformada em arte pela lente de Hussey (2014). Ou seja, é o olhar do outro que aponta nosso envelhecimento.

A construção imagética que inspira o presente escrito chama a atenção para o fenômeno da passagem do tempo até a velhice, não apenas como um fenômeno individual, a ser encarado somente pelo sujeito, mas aponta para um caráter eminentemente social. Chamando a atenção para os mecanismos de construção simultaneamente social e subjetiva do homem moderno, lembra Norbert Elias (2001) que "ser velho" é uma construção, que parte da interiorização de uma identidade individual e coletiva e,_portanto, não é algo que ocorre de uma forma homogênea.

Tampouco o inconsciente freudiano possui representações que deem conta do fato inalterável de que vamos morrer. Freud (1915) já nos avisara que exigência de imortalidade, por ser tão obviamente um produto dos nossos desejos, não pode reivindicar seu direito à realidade. E assim todos nós padecemos do medo da perda dos nossos objetos de investimento afetivo. A vida em si é alimentada por um constante gerenciamento das nossas porções de afeto, interesse, amor e tempo - sim o tempo se tornou um capital na economia moderna. 
Pode se apontar, na atualidade, uma tendência à crença na imortalidade e ao afastamento da ideia da morte._Para Elias, a passagem do tempo é algo que, quando percebido, tende a ser encarado como problemático, não tanto pelo temor do morrer, mas pelo desgosto frente à imagem antecipada da morte na consciência dos vivos (Elias, 2001).

Exemplo perfeito desse "estranhamento" é o pequeno conto La Otra, da escritora hispânico-mexicana Mariana Frenk-Westheim (2001, p.76-77):

Um dia a senhora NTS se viu no espelho e se assustou. A mulher do espelho não era ela. Era outra mulher. Por um instante pensou que fosse uma brincadeira do espelho, porém descartou esta ideia e correu a se olhar no grande espelho da sala. Nada. A mesma senhora. Foi no banheiro, no corredor, nos pequenos espelhinhos que carregava na sua bolsa, e nada. Aquela mesma senhora desconhecida estava lá. Decidiu sentar e fechar os olhos. Sentia vontade de fugir para um lugar bem longe onde não pudesse se encontrar com aquela pessoa. Porém era mais prudente ficar por perto, não deixá-la sozinha. Observá-la. Parou para refletir: quem poderia ser essa senhora? Talvez a que morou antes de mim neste apartamento? Talvez a que morará aqui quando eu sair? Ou quem sabe, a mulher que eu mesma seria se minha mãe se tivesse casado com seu primeiro namorado? Ou quem sabe, a mulher que eu mesma teria gostado de ser? Lancei uma rápida olhada no espelho e decidi que não. De jeito nenhum eu teria gostado de ser essa senhora. Depois de pensar muito tempo, a senhora NTS chegou à conclusão de que todos os espelhos da casa tinham enlouquecido, agiam como atacados por uma doença misteriosa. Tentei aceitar a situação, não me preocupar mais, e simplesmente parar de me olhar no espelho. A gente pode viver muito bem sem se olhar no espelho. Guardei os pequenos espelhos de bolsa para tempos melhores, e cobri com panos os maiores. Um belo dia, quando por força do hábito estava me penteando frente ao espelho do armário, o pano caiu, e ali estava a outra me olhando, aquela desconhecida. Desconhecida? parece-me que já não tanto assim. Contemplo-a durante longos minutos. Começo a achar que tem um certo ar de família. Talvez esta dama compreenda minha situação e por pura bondade tente se adaptar a mim, a minha imagem que por tanto tempo habitou meus espelhos. Desde então, olho-me ao espelho todos os dias, a toda hora. A outra, não tenho dúvidas, se parece cada vez mais comigo. Ou eu com ela?' (Frenk-westheim, 2001, p. 76-77).

\footnotetext{
${ }^{1}$ Un día, la señora NTS fue visto en el espejo y se asustó. La mujer en el espejo no era ella. Era otra mujer. Por un momento se pensó que era una broma del espejo, pero rechazó esta idea y corrió a mirarse en un espejo grande en la habitación. Nada. La misma señora. Estaba en el baño, en el pasillo, en los pequeños espejos que llevan en su bolso, y nada. Esa misma dama desconocida estaba allí. Decidió sentarse y cerrar los ojos. Quería escapar a un lugar lejano donde no pudo cumplir con esa persona. Pero era más prudente quedarse, no lo deje en paz. Al verla. Parado a pensar: ¿quién podría ser esta dama? ¿Tal vez eso vivió en este apartamento antes que yo? ¿Tal vez los que quieren vivir aquí cuando me vaya? ¿O tal vez la misma mujer con la que sería si mi madre se había casado con su primer novio? ¿O tal vez la mujer que yo mismo hubiera gustado ser? Eché un rápido vistazo en el espejo y decidí que no lo hice. De ninguna manera me hubiera gustado ser esa señora. Después de pensarlo mucho tiempo, la señora NTS llegó a la conclusión de que todos los espejos de la casa se había vuelto loco, actuó como atacada por una misteriosa enfermedad. Traté de aceptar la situación, no te preocupes más, y simplemente dejar de mirarme en el espejo. Podemos vivir muy bien sin mirar en el espejo. Puse los pequeños espejos de bolsos de tiempos mejores, y se cubren con paños más grandes. Un día, cuando por costumbre me estaba peinando el armario con espejo, cayó el telón, y no había otro que me mira, ese desconocido. ¿Desconocido? me parece que no tanto.
} 
O texto acima ressona as ideias de Elias, Beauvoir, Freud e_Heidegger. O "ser velho" é sempre o outro, no qual não nos reconhecemos. A imagem do velho parece sempre estar fora do sujeito, por isso, mesmo que saibamos que se trata da nossa imagem, o "ser-para-a-morte" se dá conta de uma inquietante experiência de estranheza.

Segundo, Goldfarb (1998) há algo de apavorante nessa imagem especular, algo que é, ao mesmo tempo, da ordem do familiar. "A imagem do espelho não corresponde mais à imagem da memória; a imagem do espelho antecipa ou confirma a velhice, enquanto a imagem da memória quer ser uma imagem idealizada que remeta à familiaridade do Eu especular" (Goldfarb, 1998, p. 53). Pensamos em um inevitável desencontro entre o inconsciente atemporal e o corpo envelhecido. Assim, é o olhar do outro que nos enxerga mais velho do que os demais, pois como ressalta Freud (1915) a exigência da imortalidade parece não deixar que nos demos conta do envelhecimento. Sua associação é sempre com a falta, com a perda. O velho do espelho é sempre outro, não pode ser admitido como a representação conhecida pelo sujeito de sua própria face.

\section{Envelhecer Em Tempos De Imortalidade}

As utopias ligadas à imortalidade e à juventude eterna não são novidade na história humana. No entanto, observamos uma presença forte desse desejo no imaginário contemporâneo, que tem essa aspiração reavivada pelas promessas e possibilidades que a tecnologia científica apresenta. As maneiras como lidamos com a passagem do tempo, com o envelhecimento e com a morte sofreram muitas mudanças e, hoje, é frequente a tentativa de apagar ou disfarçar os indícios desses processos.

Assim, a técnica e o mercado oferecem tratamentos médicos, prescrição de dietas, estilos de vida, cirurgias plásticas ou mesmo intervenções virtuais nas imagens, de forma que a aproximação das pessoas com o envelhecimento e com a morte seja postergada. É cultivada, simultaneamente, uma expectativa de que o

Miro fijamente durante largos minutos. Empiezo a sentir que tiene un cierto aire de familia. Tal vez esta señora entiende mi situación y tratar de adaptar la bondad pura, mi imagen que durante tanto tiempo habitó mis espejos. Desde entonces, me miro en el espejo cada día, cada hora. El otro, no tengo ninguna duda, se ve cada vez más a mí. ¿O yo con ella? 
envelhecimento possa ser paralisado e a morte adiada, indefinidamente, por meio dos avanços da tecnologia biomédica.

Esse cenário é discutido pelo historiador Lucian Boia (2006) em publicação apropriadamente intitulada: Quand les centenaires seront jeunes ${ }^{2}$. Neste trabalho, Boia apresenta o que poderíamos chamar de "tempos de imortalidade" vividos na contemporaneidade e que teve seu início tão bem descrito por Tolstoi na novela " $A$ Morte de Ivan Ilitch”, publicada ainda em 1886, na Rússia. Na obra, Ilitch declara seu conhecimento sobre a proximidade de sua morte, mas relata a impossibilidade de compreender tal fato. A lógica que havia sido perfeitamente entendida, na dimensão racional, do silogismo que apreendera: “Caio é um homem, os homens são mortais, logo Caio é mortal", parecia não fazer sentido algum quando se aplicara a ele próprio. Fato evidenciado na seguinte constatação de Ilitch:

Se eu tinha de morrer, assim como Caio, deveriam ter-me avisado antes. Uma voz dentro de mim desde o início deveria ter-me dito que seria assim. Mas não havia nada em mim que indicasse isso; eu e todos meus amigos sabíamos que no nosso caso seria diferente. E eis que agora... Não... Não pode ser e, no entanto é assim! Como entender isso? (TOLSTOI, 2005, p.63).

As consequências mais comuns no ser humano do "medo de perder algo valioso" são a antecipação defensiva e a culpa. Sempre que estamos excessivamente felizes ou em momentos importantes de nossa existência, esses mecanismos entram em ação nos informando que a felicidade ou estabilidade a qual nos encontramos pode acabar subitamente; são transitórios (Freud, 1915). A perda relaciona-se, em última análise, com o receio da morte - ou seja, a perda da existência. O homem primitivo aprendeu a admitir a morte como fato inalterável, mas não conseguiu assimilar a ideia da sua própria aniquilação. Por essa razão, a nossa história guarda uma profusão de mitos e religiões espiritualistas. De fato, nada do pulsional solicita a crença da própria morte (Freud, 1917).

$\mathrm{Na}$ contemporaneidade, como já dissemos, a experiência de envelhecer vem se transformando em função de fatores sociais, que influenciam os desafios e as identidades atreladas ao processo de passagem do tempo. Observamos várias manifestações culturais que alargam o escopo simbólico que compõem a identidade do envelhecer.

\footnotetext{
${ }^{2}$ Quando centenários forem jovens.
} 
Bauman (2005) ressalta que, durante o processo de filiação indentitária na contemporaneidade, cada vez mais os sujeitos encontram-se desprovidos de fontes seguras que lhes sirvam como parâmetros e confiram estabilidade à existência. A busca da identidade deve dar-se de acordo com parâmetros individuais e, logo, o sujeito pode contar apenas consigo mesmo para realizar seu projeto de vida assumindo responsabilidade individual pelo comportamento, pela aparência, até pela própria condição de enfermidade.

Ainda que esta relação insatisfatória e produtora de sofrimento não acompanhe a totalidade das experiências de envelhecimento, Mike Featherstone um dos principais sociólogos a se dedicar à relação entre cultura de consumo e envelhecimento - ressalta que existem diferenças entre o "corpo vivido" e os corpos virtuais que se disseminam nas representações públicas da mídia (Featherstone \& Hepworth, 2005). Os conceitos de "máscara da velhice" e "ageless" (eterno, imortal) vêm sendo frequentemente utilizados para interpretar a dicotomia entre o corpo que envelhece e a disposição interior que insiste em_fazer-se jovial como forma de filiação identitária.

As fantasias de imortalidade podem ser evidenciadas em imagens do cotidiano, a exemplo da capa quádrupla da edição da revista Superinteressante que, em fevereiro de 2010, estava nas bancas de jornais no Brasil. Nessa capa figuram hipotéticas imagens de pessoas com 40, 80 e 120 anos, mas com aspecto jovem para a idade alegada. A matéria depositava na ideia de progresso e de ciência a realização não só de um desejo, mas de uma urgência:

Você pode ser imortal: Nascer, reproduzir, morrer - eis o ciclo da vida. Mas isso é só por enquanto. A ciência está trabalhando para que ninguém mais morra de velho. E é possível que dê tempo de você entrar nessa (Cinquepalmi, 2010, p. 56).

Cinco anos antes da publicação dessa matéria jornalística brasileira, em 2005, o escritor português José Saramago inicia seu livro, As Intermitências da Morte, com a frase: "No dia seguinte ninguém morreu" (Saramago, 2005, p.11).

Nesse caso, contudo, a obra ficcional literária revela um olhar mais cauteloso e crítico do que o texto jornalístico baseado em "evidências científicas". Nesse romance, o autor parte de uma suposição: E se não houvesse mais morte? Assim, com inteligência e elegância, mas também com ironia e humor, o escritor descreve em sua narrativa o que se passa em um país onde a morte não mais existe. 
A princípio, as pessoas vivenciaram a estranheza do acontecimento, logo depois, expressaram a euforia e a alegria de se saber imortal, sonho acalentado pelos humanos desde que estes se perceberam finitos. Porém, com o passar do tempo, a alegria e a euforia deram lugar à preocupação e ao alvoroço, pois começaram a se apresentar os problemas sociais, econômicos, políticos e morais originados do fato de as pessoas não mais morrerem.

É óbvio que na realidade - diferentemente da obra de Saramago e da capa da revista Superinteressante - nós continuamos a morrer. Entretanto, a relação de muitos homens contemporâneos com a morte tem sido permeada pelo distanciamento, pela técnica, pela institucionalização, pela medicalização e pela mercantilização.

A morte afronta a utopia da imortalidade e passa a ser escamoteada, escondida, e quem morre "deletado", lembra a pesquisadora Paula Sibília (2008). O verbo utilizado pela autora- é utilizado de forma salutar, pois a morte - enquanto uma existência que cessa, algo "deletado" - pois desvela que o existir, na contemporaneidade, não vale apenas para o corpo vivido, mas para todo o conjunto das suas representações, do corpo virtual, sejam elas em espaços "reais" ou “virtuais". Não ocupar tais espaços é como não existir (Bauman, 2011).

O morrer deixa de ser um momento já esperado do desenvolvimento humano para se configurar como uma derrota, como um fracasso. Conforme afirmam Soares e Dantas (2006, p.100): “O homem hipermoderno tende a ver a morte como uma traição, cometida pela tecnociência, que se apresentou a ele como onisciente e onipotente, que lhe prometeu eterna juventude e imortalidade".

Norbert Elias (2001) comenta os modos pelos quais se instalam os sentimentos de constrangimento, medo e embaraço em relação a tudo que lembre a finitude da vida biológica; dando especial relevo ao isolamento dos velhos e moribundos em asilos, hospitais e clínicas de saúde. Segundo o autor 2 o abandono e isolamento dos velhos em nossa sociedade não podem ser explicados unicamente a partir da ideia de que velho é improdutivo economicamente. Pais e professores evitam falar da morte, de pessoas que morrem ou estão morrendo. As crianças, muitas vezes, são impedidas de verem pessoas mortas e, por conseguinte, de vivenciarem as emoções provocadas pela morte.

\section{O Imperativo da Felicidade e A Medicalização da Vida}


Ao pensar na relação do Homem com o tempo e com a finitude, são pertinentes os questionamentos: Qual o tempo destinado ao sofrer na sociedade ocidental contemporânea? De que maneira o período do luto é abreviado em uma época que valoriza, e mesmo impõe aos indivíduos, o "ser feliz"?

A experiência com as situações de morte e morrer advém, primeiramente, da morte do outro, que nos remete à percepção de que também somos seres para a morte e que, em algum momento de nossa existência, passaremos pelo mesmo processo. As tentativas de amortecer esse tipo de experiência desconfortável, apesar da sua imanente inevitabilidade, parecem constituir a lógica corrente de lidar não apenas com a morte, mas com tudo que a ela se relaciona ou imprime semelhante sofrimento.

Vivenciar a alternância entre vivências de felicidade e de tristeza faz parte da experiência pessoal da maioria dos seres humanos, porém, na contemporaneidade, a proporção esperada de cada um desses polos tem sido bastante modificada. Estamos diante do que podemos chamar "imperativo da felicidade" (Freire Filho, 2010), pois a felicidade é colocada como condição indispensável de bem estar e sucesso pessoal e as formas apontadas pela sociedade para sua obtenção são as mais diversas, contudo em sua maioria ligadas ao consumo e à imagem.

No entanto, não é suficiente ser feliz, em uma sociedade do "culto da performance" (EHRENBERG, 2010) temos que ser o mais feliz dentre os outros. Se estamos bem, por que não podemos ficar melhor? Esse é o pressuposto do conceito de "melhor que bem", muito utilizado na chamada "Psiquiatria cosmética" que - diferentemente da acepção derivada do grego para a "arte de curar a alma" concebe o uso dos medicamentos psicotrópicos não só como auxilio às pessoas com quadros patológicos, mas como potencializador de características desejáveis em uma sociedade performática.

As fronteiras entre tratamento e aperfeiçoamento, segundo o psiquiatra Benilton Bezerra, estariam indefinidas para a psiquiatria, que se voltaria: "Não apenas ao tratamento, mas ao alívio do sofrimento inerente à vida cotidiana e aos limites naturais da vida, bem como pela produção biotecnológica de estados de felicidade" (Bezerra, 2010, p.121). 
O uso elevado e frequente de medicações ou intervenções para a melhoria de um estado ou característica das pessoas foi comparado pelo sociólogo Ehrenberg (2010) com o doping dos atletas, cujo objetivo não seria um tratamento, e sim, uma melhoria de suas performances. No caso dos não-atletas, performances profissionais, sexuais, estéticas, enfim, a busca da tão propagada (e propagandeada) felicidade. A competição permeia todo esse contexto, posto que o conceito do "melhor que bem" nos lembra que não é suficiente ser bom ou feliz, é necessário ser o melhor e o mais feliz. O sociólogo questiona se não estaríamos lidando com drogas de integração social e relacional, considerando o consumo disseminado de medicamentos psicotrópicos destinados aos mais diferentes objetivos de melhorias de performances (Ehrenberg, 2010).

Ao que parece, em uma sociedade que cultua a performance, a tolerância com as diferenças tem diminuído. Na medida em que, ao nível da representação, se vêem diminuídas as possibilidades de contribuição para a sociedade (apesar de ser um momento onde se deveria estar gozando o benefício de uma vida inteira de trabalho) o "ser velho" passa a ser entendido como "fardo", o que tem seus impactos na construção social do envelhecer (Featherstone \& Hepworth, 2005). Nesse cenário o velho, por exemplo, que encarna tanto a discrepância do modelo publicitado quanto a face inescapável da morte, tem se tornado cada vez mais um pária social.

Com relação ao descaso para com os idosos, Simone de Beauvoir afirma que nossas sociedades não são apenas culpadas, mas criminosas. Extenso estudo bibliográfico realizado em seu livro $A$ Velhice leva a autora a considerar que os velhos, em algumas sociedades, encarnam a categoria de Outro do social, portando toda ambivalência característica a este conceito. Ou bem o velho é reconhecido como uma espécie de super-homem, ou tratado como uma subespécie da raça. Ele sempre está além ou aquém da condição normal dos demais homens. Esse cenário cria diversas situações martirizantes para aqueles que viveram mais anos do que o aceitável pela sua própria comunidade (Beauvoir, 1990).

Outra questão é o fato de o estatuto da velhice ser outorgado pela comunidade. Seu status social e subjetivo pouco ou nada depende de suas próprias capacidades, sendo determinado pelos ideais e objetivos da sociedade na qual se encontra inserido. Podendo ser valorizado ou descartado, de acordo com as exigências da nova onde midiática da próxima estação. Nas palavras da escritora Eliane Brum 
(2008, p. 58) os velhos do nosso tempo se encontram "reduzidos a um único tempo verbal, o pretérito, com suspeito presente e um futuro que ninguém quer".

Além disso, vivências e estados subjetivos, antes considerados como indissociáveis do viver de qualquer pessoa, têm figurado como patológicos ou indesejáveis, de modo que devem ser tratados ou evitados. Bezerra (2010) observa que a compreensão do sofrimento psíquico como instrumento de transformação pessoal, presente nas correntes psicodinâmicas e fenomenológico-existenciais, vem dando lugar a concepções diferentes, que classificam o sofrimento como desnecessário e mesmo patológico. Um exemplo dessa realidade é a medicalização da tristeza e do luto.

A sociedade contemporânea tem elegido a medicalização do viver como alternativa para lidar com essas questões. Assim, a medicalização não só da tristeza, mas de outras vivências humanas, do nascimento à morte, coloca no domínio técnico âmbitos antes não pertencentes à clínica médica.

Assim, parece pertinente questionar, seria por conta desse processo de medicalização do viver e do envelhecimento - que não causou grande surpresa o fato do trabalho fotográfico Reflections - ponto de partida das reflexões desse artigo, ter sido vendido para a campanha publicitária de um medicamento para Mal de Alzheimer?

As reflexões aqui realizadas mostram que, atualmente, o tempo destinado ao sofrer tem diminuído, por outro lado tem aumentado o sofrimento diante da percepção da passagem do tempo, que remete ao envelhecimento e à morte. Apesar dos dados demográficos de aumento da expectativa de vida e o consequente envelhecimento da população humana, em países desenvolvidos ou em desenvolvimento, a sociedade contemporânea ocidental tem demonstrado menos tolerância com os sinais desse envelhecimento.

Para camuflar os sinais da passagem do tempo, são utilizados os mais diversos artifícios. Com esse objetivo, são cada vez mais frequentes as intervenções, sejam no corpo, nas imagens virtuais e mesmo na linguagem. No corpo, o apagar dos indícios do escoamento do tempo, do envelhecimento, utiliza desde a aplicação de toxina botulínica para paralisação dos músculos e redução das rugas a cirurgias plásticas, cosméticos, exercícios, medicamentos, dietas controladas e até injeção de células-tronco. Nas imagens virtuais, em um mundo imagético e performático, a ingerência sobre o envelhecimento se dá com os meios 
virtuais de rejuvenescimento, como os recursos do "photoshop", ou "filtros" utilizados para intervenções nas imagens das pessoas em fotos e vídeos.

$\mathrm{Na}$ linguagem, podemos observar uma profusão de termos como "Terceira Idade", "Melhor Idade", "Idoso" "Espírito Jovem", "Sênior", que, ao se referir ao velho e ao envelhecimento, faz uso de constante eufemismo. Essa figura de pensamento, o eufemismo, é conceituada pelos gramáticos como um tipo de linguagem que substitui uma expressão rude por outra mais agradável, para não gerar ofensas ao comunicar alguma coisa áspera, desagradável ou chocante. A utilização frequente dessa estratégia linguística para tratar o velho coloca em cena a nossa relação com o envelhecimento, permeada pela negação, evitação e patologização.

\section{Considerações Finais}

Se antes falávamos da velhice em termos apenas de perdas cognitivas e executivas, hoje comemoramos entusiasmados as conquistas da medicina e os avanços legais e sociais de alguns países na defesa dos direitos dos velhos. Envelhecer como sinônimo de decadência deixou de ser uma profecia autorrealizável (Vilhena, Novaes \& Rosa, 2014).

Mas sabemos que tal como a bela paisagem lamentada pelo amigo de Freud em seu texto sobre a transitoriedade, quando sobrevier o inverno da alma, estas maravilhas, estes avanços, rapidamente serão solapados pela inexorabilidade do processo vital.

Pior do que a decadência física nos parece ser a condição de desamparo que a contemporaneidade impõe a todos e, em especial, aos velhos. Falamos aqui de um desamparo estrutural, fruto de uma sociedade que optou por abrir mão de seus baluartes e garantidores em nome de um estilo de viver mais fluído, descompromissado e mesmo superficial.

Vivemos um tempo de falta de garantias, onde há poucos pontos de sustentação na vida que não sejam o próprio consumo, o capitalismo, a eterna busca de uma quimera chamada felicidade, como estratégia de evitação quase que automática da falta mais intrínseca a todos. Esta lacuna no ser humano 
contemporâneo, que era a mesma do homem moderno, já nos garantia Freud, diz respeito aos ideais que são erigidos na base de nossa constituição subjetiva, ou seja, os ideais de onipotência, de propriedade exclusiva do amor materno e, quando tudo mais falha, da proteção do pai todo poderoso. A diferença reside exatamente na maneira como os homens dessas duas épocas lidam com tais questões.

Modos distintos de se relacionar com o envelhecimento, que aqui optamos por evidenciar, com o auxílio de mais uma obra de arte, porém agora escrita pela pena de William Shakespeare (1599). Trata-se de uma parte da trajetória do Rei Henrique V, contada no livro que leva o nome do monarca. Lá estava o exército inglês, às portas de Azincourt, no auge da famosa Guerra dos Cem Anos. Os ingleses já haviam tomado grande parte da França, mas suas hostes se encontravam em frangalhos, destruídas pela fome, pela peste e, é claro, pelo exército inimigo.

Às vésperas da grande batalha Henrique V decide sondar o moral das tropas disfarçando-se de reles camponês e caminhando entre as fileiras de seus homens. Em dado momento ele ouve dois soldados conversando sobre o que o alvorecer os reservava, quando um deles questiona seu companheiro de campanha:

- E se você morrer amanhã?

- Ora. Se eu morrer eu acho que serei julgado pelos meus atos. Provavelmente, vão me perguntar por que eu matei tantos homens. Então, eu poderei dizer que matei porque o Rei mandou. Sou um fiel súdito da coroa, e se o rei manda ir à guerra e matar franceses, então é isso que eu faço. Por isso estou tranquilo para morrer por meu país.

Ao escutar essa conversa, o rei toma-se de um súbito desespero por não saber se estava tomando a decisão certa ao levar seus homens para o que poderia ser a morte e a destruição do seu exército. Neste momento Shakespeare narra que os soldados, mesmo deitados no solo duro, dormem tranquilamente, confiantes nas decisões do rei, garante último de suas vidas. Enquanto Henrique, posto num dossel esplêndido, cravejado de ouro, contempla a noite horrenda que nada lhe responde sobre seus dilemas.

O homem moderno, oriundo dos sistemas de governo unificados na figura de um representante máximo, crente nas ideologias religiosas, encontra bases que possam lhe dar o suporte necessário para a caminhada de sua existência, tal como os soldados ingleses. Ao tempo em que o sujeito da contemporaneidade, muito se assemelha ao Rei, que não tem ídolos, sábios, ou mestres a quem endereçar suas 
angústias vivenciais. Acrescente a este quadro a série de angústias trazidas pelo envelhecimento (debilidade física, preconceito, castração, morte), e a incapacidade da sociedade atual em lhes dar qualquer resposta satisfatória e não paliativa e teremos uma mostra da condição de desamparo do velho nos dias atuais.

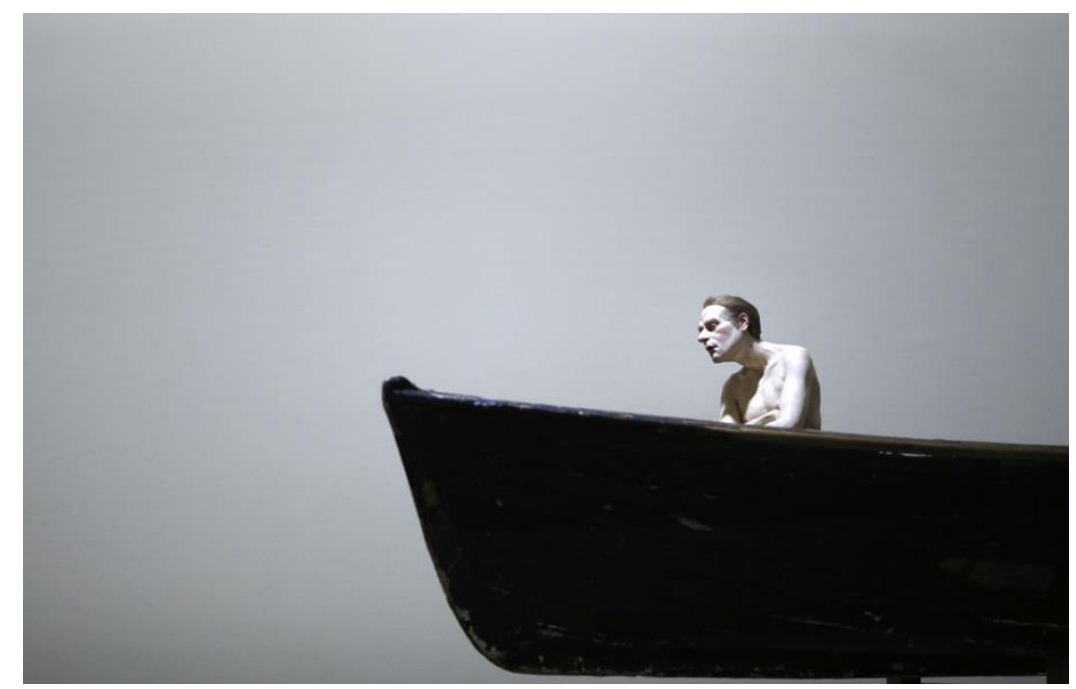

Figura 2. Escultura "Homem em um Barco" $159 \mathrm{~cm}$ x $138 \mathrm{~cm}$ x 425,5cm. Ron Mueck. 2002

Tal como o desamparo de um homem, que navega solitário e desnudo, na escultura hiper-realista de Mueck (figura 2), um enorme barco sem leme ou remos. E que, com seus braços cruzados e grande palidez, lança longo olhar. Mas... Para onde?

\section{Referências}

Bauman, Z. (2005). Identidade. Rio de Janeiro: Zahar.

Bauman, Z. (2011). 44 cartas do mundo líquido moderno. Rio de Janeiro: Zahar.

Beauvoir, S. D. (1990). A velhice. Rio de Janeiro: Nova Fronteira, 3.

Bezerra JR, B. (2010). A psiquiatria ea gestão tecnológica do bem-estar. Ser feliz hoje: reflexões sobre o imperativo da felicidade. Rio de Janeiro: Editora FGV.

Boia, L. (2006). Quand les centenaires seront jeunes: l'imaginaire de la longévité de l'Antiquité à nos jours. Belles lettres. 
Brum, Eliane. (2008) O olho da rua: uma repórter em busca da literatura da vida real. São Paulo: Globo.

Cinquepalmi, J. V. (2010). Você pode ser imortal. Super Interessante, 14.

Elias, N. (2001). A solidão dos moribundos: seguido de "envelhecer e morrer". Tradução: Plínio Dentzien. Rio de Janeiro: Jorge Zahar Editor.

Ehrenberg, A., Tradução de Marianna, T., \& Winograd, M. (2009). Osujeito CEREBRAL. Psicologia clinica, 21(1), 187-213.

Featherstone, M., \& Hepworth, M. (2005). Images of ageing: cultural representations of later life. The Cambridge handbook of age and ageing, 354-362. Freire Filho, J. (2010). A felicidade na era de sua reprodutibilidade científica: construindo" pessoas cronicamente felizes. In: FREIRE FILHO, J. (org.) Ser Feliz Hoje: reflexões sobre o imperativo da felicidade. Rio de Janeiro: FGV, 2010.

Frenk-Westheim, M. (2001). Y mil aventuras. Siglo XXI.

Freud, S. (1974). Sobre a transitoriedade. Edição standard brasileira das obras psicológicas completas de Sigmund Freud, vol. XIV.

Freud, S. L. (1974). Luto e melancolia. Edição Standard Brasileira das Obras Psicológicas Completas de Sigmund Freud, vol. XIV.

Goldfarb, D. C. (1998). Corpo, tempo e envelhecimento. São Paulo: Casa do Psicólogo.

Heidegger, M. (1988). Ser e Tempo. Petrópolis: Ed. Vozes.

Hussey, T. Reflections. Hussey Photography. Dallas, fevereiro, 2014. Recuperado em 10 julho de 2014,de: <http://www.tomhussey.com/SERIES/Reflections/1/thumbs>.

Meireles, Cecília. (1958) Obra Poética. Rio de Janeiro: José Aguilar.

Saramago, J. (2011). As intermitências da morte. Leya.

Shakespeare, W. (1599) Henrique V. São Paulo: L\&PM EDITORES.

Silva, C.A. (2014) Proust, Bergson, Benjamin: breve nota sobre o tempo, a duração e a modernidade na "busca do tempo perdido". Jornal Opção, Goiânia, 29 de maio de 2011. Recuperado em 10 maio de 2014, de: <http://www.jornalopcao.com.br/posts/opcao-cultural/proust-bergson-benjaminbreve-nota-sobre-o-tempo-a-duracao-e-a-modernidade-na-busca-do-tempoperdido>.

Sibilia, P. (2008). O show do eu: a intimidade como espetáculo. Nova Fronteira. 
Soares, J. C., \& Dantas, M. A. (2006). Considerações sobre a morte eo morrer na hipermodernidade. Estudos e Pesquisas em Psicologia, 6(2), 89-104.

Vilhena, J., Vilhena Novaes, J., \& Rosa, C. M. (2014). A sombra de um corpo que se anuncia: corpo, imagem e envelhecimento. Revista Latinoamericana de Psicopatologia Fundamental, 17(2).

Tolstoi, L. (1997). A morte de Ivan Ilitch. Porto Alegre: L\&PM. 


\title{
Quarto Artigo - Eternamente jovens? Beleza e envelhecimento nos processos de subjetivação feminina
}

\author{
Artigo submetido a Psicologia em Revista. \\ Autores: Carlos Mendes Rosa, Junia Vilhena, Eduardo Santos \\ Recebido em: 06/02/2015 \\ Aceito em: em avaliação \\ As referências bibliográficas foram mantidas no formato original da revista.
}

\section{Resumo}

O presente artigo é uma reflexão teórica sobre as práticas de rejuvenescimento adotadas por muitas mulheres em nossa sociedade. Adotando o referencial psicanalítico como base, analisamos o impacto atual de significantes como morte e feiura, bem como o silenciamento imposto a estes, para propor uma leitura diferente acerca das tentativas de manutenção da aparência jovial. Pensamos serem estas ações, quando constantes e quase definidoras da subjetividade da mulher, expressões no corpo de afetos impossíveis de simbolização e representação pela via da fala, tal como uma nova modalidade de funcionamento histérico. Apontamos ainda para a supervalorização das formas físicas da mulher em detrimento de sua experiência de vida, traço marcante da cultura espetacularizada e hedonista, como uma das principais causas de sofrimento em mulheres velhas. E questionamos se existe alguma possibilidade de escapar desta lógica massacrante e tão arraigada em nossa cultura.

Palavras-chave: envelhecimento; histeria; psicanálise; subjetividade

Forever young? Beauty and aging in female subjectivity processes 


\begin{abstract}
This article is a theoretical reflection about the rejuvenation practices adopted by many women in our society. Adopting psychoanalytic approach as a basis, we analyze the current impact of significant as death and ugliness as well as silencing imposed them to propose a different reading about the attempts to maintain the youthful appearance. We believe being these actions, when constant and almost defining women's subjectivity, expressions on the body, of affections impossible to symbolize and represent by the speech, such as a new kind of hysterical functioning. We still aim for the overvaluation of the physical forms of women at the expense of their life experience, a striking feature of spectacularized and hedonistic culture, as a major cause of suffering in older women. And we question whether there is any possibility of escape from this overwhelming logic so ingrained in our culture nowadays.
\end{abstract}

Keywords: aging; hysteria; psychoanalysis; subjectivity 
E assim se percebe que homem e mulher são apenas, e já é bom, potenciais objectos portáteis e mortais. Gonçalo Tavares

Morte, esse significante tão problemático e assustador para os sujeitos, o inefável daquilo que não pode ser representado. Pensar na velhice é pensar primeiro na possibilidade de morrer, e logo em seguida na possibilidade de não ter que pensar na morte.

Em trabalho recente acerca do morrer na contemporaneidade e das práticas funerárias, Lana Veras (2014) afirma que nos tempos atuais a morte é "feia", é "velha", é "suja" e os mortos, "contaminam". Por essa razão, "devem ser adotadas todas as ações que "corrijam" essas desagradáveis características e expressem beleza, juventude, assepsia, tranquilidade, conforto". A constatação da autora acerca dos estereótipos que cercam o fenômeno da morte nos dá uma dimensão do horror que a sociedade adquiriu em relação à finitude da existência.

Baudrillard (1997) nos diz que é no século XVI que essa figura moderna da morte se generaliza, porque antes a morte era vivenciada de maneira diversa. Ao observarmos as imagens da Idade Média, vemos dançando o rei, a corte, o guerreiro e a morte, representada pelo esqueleto dançando junto com as pessoas (Vilhena, Novaes e Rosa, 2014a). A descrição se refere à imagem mais popular da morte na Idade Média, segundo Huizinga (2010), a Dança Macabra, uma alegoria sobre a universalidade da morte que lembrava sua inevitabilidade, funcionando como comunicação da moral vigente e controle social.

Na Idade Média, segundo Ariès (2000), a morte era vivenciada com familiaridade e maior serenidade. No entanto, apesar de maior abertura para tratar do tema, havia, também nessa época, o temor à morte. Diferente, contudo, do temor 
contemporâneo, que evita os indícios da finitude no corpo, o medo da morte na Idade Média estava ligado à punição no além, medo influenciado pela forte religiosidade do período. (Elias, 1994; Veras, 2014; Vovelle, 1974,1983).

Essa proximidade com que a morte é tratada na Idade Média, com traços marcados de aceitação da inexorabilidade e universalidade do processo de morrer, se modifica nos séculos posteriores. A visão coletiva do juízo final cede espaço, com o surgimento do indivíduo, a um julgamento no qual cada alma é sujeita a uma espécie de exame onde tudo da sua biografia é levado em conta. A mudança nas atitudes diante da morte ocorreu paulatinamente nos séculos que se seguiram à Idade Média. Entretanto, entre o final do século XIX e início do século XX se processa uma alteração intensa nas maneiras de lidar com a morte e o morrer. A morte passa a ser interdita, concebida como fracasso, impotência ou imperícia, deve ser evitada ocultada e silenciada (Ariès, 2000, 2003). De maneira que, se repararmos nos adjetivos utilizados pela autora da tese citada no início desse artigo, não encontraremos o medo reverente dos antigos tempos, mas um asco, uma certa repulsa de morrer.

Grandes pensadores como Freud e Foucault também apontaram esse espinho encravado no narcisismo das sociedades modernas. No seu belíssimo ensaio acerca da cultura Freud (1930) escreveu que uma das três principais fontes do sofrimento humano estaria relacionada ao não controle sobre os destinos de um corpo com marcha constante em direção ao seu próprio fim. Para ele, viver em sociedade exigiu do ser humano uma renúncia pulsional, devido a existência de um antagonismo entre as exigências das pulsões e as da civilização.

Observando a sociedade atual podemos acrescentar que o apego aos invólucros neurolépticos que atenuam tal conflito também não resolve o problema. 
Esta alternativa moderna também provoca mal-estar, à medida que oferece um corpo mercadoria, tanto da indústria cultural quanto da indústria da saúde. Mesmo que vivenciemos, hoje, um avanço tecno-científico que proporciona mais saúde ao corpo, apenas somos capazes de prolongar o nosso sofrimento, adiando, quando muito, o fechar de cortinas para o espetáculo da vida.

Em Reflexões para os tempos de guerra e morte, o Mestre de Viena apresenta novamente a sua preocupação para com o tema da morte, já que como "criaturas civilizadas, tendemos a ignorar a morte como parte da vida". Como nos diz Freud, nenhum de nós acredita na própria morte e nem mesmo consegue imaginá-la. "Uma convenção inexplícita faz tratar com reservas a morte do próximo. Enfatizamos sempre o acaso: acidente, infecção, etc., num esforço de subtrair o caráter necessário da morte. Essa desatenção empobrece a vida" (Freud, 1916, p. 300).

O homem primitivo aprendeu a admitir a morte como fato inalterável, mas não consegue assimilar a sua própria aniquilação. Nada do pulsional solicita a crença da própria morte; além do fato da experiência da morte representar a castração por excelência, uma vez que é irreversível e incapaz de ser compensada através de substitutos (Gonçalves, 2001).

Nas palavras de Foucault; "Agora é sobre a vida e ao longo de todo o seu desenrolar que o poder estabelece seus pontos de fixação; a morte é o limite, o momento que lhe escapa; ela se torna o ponto mais secreto da existência, o mais “privado"." (1988, p. 130).

O célere correr das horas na inexorável marcha para o fim cria uma relação de profunda angústia do homem com o tempo, esta sublime metáfora criada para 
encobrir a incômoda verdade de que são os seres que passam e não o próprio tempo (Soares \& Dantas, 2006).

Ainda assim, o tempo passou a ser um elemento fundamental no jogo de poder da atual sociedade, por esta razão as instituições da modernidade comprometidas com as políticas de disciplinamento e controle social, através de seus discursos e seus agentes atuam demarcando territórios e ordenando os tempos, outorgando e expropriando propriedades, a propriedade do tempo e do espaço, o território do público, o espaço do íntimo, o lugar do silêncio, o lugar da palavra, daquele que tem a propriedade da palavra, daquele que fala com propriedade, a palavra do proprietário. O tempo próprio, o tempo da demora no pensar, o tempo de dizer e de fazer, o tempo de escutar e ser escutado, o tempo do outro, o outro tempo, o da invenção e das possibilidades de inventar, o tempo da subversão (Vega, 2011).

Nesse sentido, o tempo da velhice, prelúdio da morte, se contamina com adjetivos similares aos utilizados pela sociedade em relação à esta última. Cerqueira Filho (2013, p. 172) descreve o encontro com a morte no conto de Guimarães Rosa. "Não a morte final - equestre, ceifeira, ossosa, tão atardalhadora, mas a outra, aquela". Onde o "homem fica com alguma coisa de cadáver". A aparência de nossos velhos fazem com que nos lembremos dos cadáveres?

Paula Sibilia dirá que em nossa sociedade "a velhice é censurada como algo obsceno e vergonhoso, que deveria permanecer oculto, fora da cena, sem ambicionar a tão cotada visibilidade" (Sibilia, 2011, p. 94). A obscenidade interdita da velhice na contemporaneidade emerge como um desdobramento do que o sociólogo inglês Geoffrey Gorer (1995) denominou, ainda na década de 50, como "Pornografia da Morte", momento em que a morte tomara o lugar da sexualidade 
como principal tabu ocidental, tornando-se fonte de pudor, passando a ser indecente, suja e, por conseguinte, tem início seu processo de camuflagem, ela é, em palavras de Nobert Elias, “empurrada para os bastidores” (Elias, 2001).

Aqui faz sentido a assertiva de Adorno (1948, p. 46) acerca dos mecanismos higiênicos e excludentes da cultura atual. "Quem resiste aos mecanismos de adaptação já não é considerado o mais capaz. Já não procura sua própria conservação através da adaptação, é visto com menosprezo: como deformado, atrofiado, fracote".

Adjetivos estes que, muitas vezes, se estendem aos velhos, principalmente no campo da sexualidade. Foi Aristófanes com suas peças teatrais quem tratou de acrescentar um tom de mordaz comicidade à existência do sujeito velho. A figura do velho libidinoso foi mote de várias obras do mestre da comédia grega. As gregos se fartaram de rir à custa de caricaturas de velhos que desejavam manter-se ativos sexualmente e eram humilhados pelos mais jovens.

Ao longo da idade média a figura do idoso sábio retoma alguma espaço no cenário social e sua postura venerável ostenta sempre a companhia de uma mulher, também digna de respeito. Por esta razão vemos até o século XIX, matronas maduras e pesadas, usualmente vestidas de negro, enfeitando álbuns de família. Entretanto, no século XX, tais figuras tendem a desaparecer da vida pública. Mostra de que o envelhecer começa a ser associado à perda de prestígio e ao afastamento do convívio social (Del Priore, 2012).

Esse estereótipo que atravessa o tempo e vai fazer morada no imaginário social de quase todas as civilizações (Beauvoir, 1990), ganha uma expressão potencializada nos dias de hoje. Em exposição recente no Museu de Arte Moderna (MAM) do Rio de Janeiro, as obras de Ron Mueck causaram espécie nos visitantes 
que ali se encontravam. Algumas figuras desnudas de homens e mulheres velhos, bastante detalhistas e em escala aumentada, levavam o transeunte aos risos (às vezes de escárnio, outras de nervoso) diante do contato com a sexualidade na velhice.

Uma das consequências diretas do desprezo histórico pela sexualidade dos velhos é o fato do sexo na velhice se constituir como tabu. E não sem razão, pois, especialmente antes dos remédios para impotência, mas também após a sua chegada, o velho encarna o fantasma que persegue os jovens no auge de sua potência, desvelando antecipadamente o destino inexorável que os aguarda.

É claro, que não foi apenas a sexualidade do idoso a ser discriminada e vista com estranheza. A própria velhice, com suas manifestações naturais, se patologizou em diversas categorias diagnósticas nos manuais médicos. Um certo isolamento do mundo passa a ser visto como fobia social, a perda de vitalidade pode ser chamada de depressão, os ciclos de sono e vigília recebem rótulos e medicamentos. Nos faz recordar a afirmação de Marcuse (1999) que a tecnologia pode ser considerada como uma forma de organizar as relações sociais de modo a beneficiar a ideologia dominante, servindo como um instrumento de controle e dominação.

É evidente que na nova configuração societária a velhice ganha variados contornos, sendo caracterizada por uma multiplicidade de processos sociais. A figura do velho deixa de ter um "perfil monolítico" e se desdobra em um conjunto de figurações, marcadas "pela matização, pela diferença e pela polivalência" (Birman, 2013, p. 52). Nesse sentido, estamos optando por um recorte epistemológico que privilegia as mulheres que se submetem a tratamentos cirúrgicos ou medicamentosos e outras modalidades de intervenção com a finalidade de manterem uma aparência mais jovem. 
Nossa escolha se justifica pelo fato de que nenhuma outra faceta do envelhecimento foi tão violentamente atacada quanto a aparência. Em tempos de culto extremo à imagem, de super exposição através das mídias digitais, onde o corpo entra em cena como capital a ser explorado, comercializado, vendido ou trocado por qualquer outra mercadoria, encontramos um novo tipo de investimento que não tem mais a forma de controle-repressão, mas de controle-estimulação: "Fique nu... mas seja magro, bonito, bronzeado" é o que nos diz Foucault (1996, p. 147).

Atendendo ao convite escancarado por Foucault a mulher do nosso século realmente se despiu. Como afirma Del Priore (2012) o nu na televisão, nas revistas e nas praias, incentivou o corpo a desvelar-se em público, banalizando-se sexualmente. Este fato cria a demanda de se cobrir o corpo com cremes, vitaminas e silicone. A pele tonificada, alisada, apresenta-se idealmente como uma nova forma de vestimenta, que não deve enrugar nem “amassar" jamais. Diferente das mulheres de tempos passados, as de hoje não se preocupam mais em salvar suas almas, mas em salvar seus corpos da desgraça da rejeição social. O tormento maior, não é o fogo do inferno, mas a balança e o espelho.

Quando uma mulher idosa se olha no espelho, o que este lhe devolve é uma imagem ligada a uma deterioração, uma imagem com a qual ela não se identifica. Existe uma discrepância entre a imagem inconsciente do corpo e a imagem refletida, posto que se trata de um sujeito psíquico em constante crescimento e evolução. Esse desencontro entre o inconsciente atemporal e o corpo que envelhece porta efeitos traumáticos cuja complexidade situa-se no arranjo entre corpo, subjetividade e laço social (Vilhena, Novaes \& Rosa, 2014a). 
Daí os mais variados discursos que, ora negam a existência do envelhecimento através de paroxísticas atividades rejuvenescedoras (que vão desde as academias até a poderosa indústria antiaging, cujo faturamento nos Estados Unidos está chegando a impressionantes US\$ 100 bilhões ao ano, quando há vinte anos atrás esse setor sequer existia na economia americana), ora a embelezam com nomes que nada têm a ver com sua verdadeira significação, como "melhor idade" e tantos outros.

Como afirma Sibilia (2011) as barreiras interpostas pelo envelhecimento e a morte, que sempre constituíram graves limites para a expansão dos corpos humanos, hoje estão sendo dinamitadas. As novas ciências flertam com a possibilidade de "reprogramar" os corpos para torná-los imunes às doenças, driblando tanto as penúrias da velhice como a fatalidade da morte. Trata-se da miríade da eterna juventude, renovada não só como a grande ambição da nossa época, mas principalmente como uma promessa que, logo estará à disposição de todos - todos aqueles que tenham condições de pagar por isso.

Entretanto, enquanto ainda não se consuma esse fabuloso anseio, e nossos corpos envelhecem inexoravelmente, para o nosso desespero, necessitamos de antídotos que nos ajudem a lidar com tamanho desatino. Nesse sentido novas tecnologias - em estreita aliança com a mídia e o mercado - oferecem variado cardápio de soluções alternativas e sempre temporárias, que se destinam a “contornar essa defasagem entre tão soberbas ambições e as metas ainda modestas que por enquanto são atingíveis". Nesse fabuloso acervo de paliativos se incluem tanto as variadas técnicas de rejuvenescimento quanto as drogas para apaziguar as angústia da alma, uma vez que "as primeiras jamais conseguem a eficácia prometida 
e o decepcionado consumidor precisará, portanto, de algum outro consolo” (Sibilia, 2011, p. 89).

\section{Histeria e envelhecimento}

Nosso objetivo é tentar compreender as práticas e discursos que tentam associar o fenômeno do envelhecimento à feiura e à morte e, por consequência, fazê-lo desaparecer do cenário social. Para isso traçaremos um paralelo entre as práticas de rejuvenescimento propostas e utilizadas pelas mulheres velhas e aquilo que Freud denominou de histeria ou comportamento histriônico, segundo as nomenclaturas mais modernas.

A histeria surge como protótipo das patologias do aparelho psíquico desde a fundação da psicanálise. Bertha Pappenheim, Fanny Moser, Miss Lucy R, as primeiras, e mais famosas pacientes de Freud, apresentavam, todas elas, algum sintoma considerado histérico. Em uma o corpo se revolta em convulsões, em outra a língua não se controla e estala, outra perde completamente o olfato. Manifestações conversivas de diferentes matizes, porém todas oriundas da mesma fonte, qual seja a impossibilidade de lidar abertamente com a pulsão sexual.

Aqui uma defesa é elaborada pelo ego, através do recalque, com o intuito de afastar uma representação incômoda à consciência e todos os seus aprioris morais. Então, o conflito psíquico se estabelece, quando surge esta representação incompatível com o ego, e este esforça-se em se defender, não sem efeitos patológicos, mandando a lembrança aflitiva para o inconsciente, enfraquecendo o afeto, o qual é convertido em sintoma (Freud, 1926).

Dito de outra maneira, a "verdrangung" freudiana consiste em manter algo à distância da consciência, entretanto, tal ação não impede que o representante 
pulsional continue a existir no inconsciente, onde ele se organiza e dá origem a derivados e associações. Na histeria conversiva, por exemplo, há um deslocamento dos conteúdos inconscientes, para o corpo, produzindo o sintoma conversivo via retorno do recalcado.

Do ponto de vista econômico, tal passagem se opera, esquematicamente, da seguinte maneira: a energia libidinal desliga-se da representação, no processo de recalcamento, deslocando-se para o corporal (Freud, 1895). Entretanto, a explicação econômica não exclui a concepção simbólica dos sintomas: os quais seriam a expressão de conflitos psíquicos, transformados pelo deslocamento e pela condensação, de modo que um sintoma expressa significações, exigindo a suposição de que o corpo tem existência na e pela linguagem, tornando-se palavra (Solero-de-Campos \& Winograd, 2012).

Freud também chegou a pensar na histeria como uma forma de pensar por contiguidade, conceito que deriva das ideias de Hartley e seu paralelismo psicofísico, e expressa a capacidade que o psiquismo tem de associar estímulos que são apresentados simultaneamente e, em momento posterior, retomar tais associações apenas com a presença de um dos estímulos. O paralelismo psicofísico também considera eventos psicológicos e físicos separadamente, no entanto, concebe que os mesmos podem atuar em paralelo e se interpenetrar. Essa ideia, por mais simples que possa parecer, e tão fácil de ser demonstrada através, por exemplo da hidrofobia de Ana O., nos será útil em nossa argumentação acerca das novas manifestações histéricas na velhice.

Freud localiza a histeria nas primeiras fases do desenvolvimento infantil, quando a mulher, principalmente, recusa-se a abrir mão do desejo pelo pai idealizado. Note-se que já houve a troca do objeto amado, vez que todos nós temos 
por primeiro objeto de amor a mãe. Ocorre, porém, uma fixação da menina neste enamoramento pelo pai, que resultará tanto na dificuldade de lidar com as perdas, quanto em um certo caráter fálico, que pode ser expresso nas ações ou no modo de se apresentar (formato e adereços do corpo). Falando das ações, podemos pensar na tentativa histérica de ser o falo do outro, ou seja, ser aquilo que falta no outro, conseguindo com isso, na maior parte dos casos, ser apenas escravo do desejo do outro. Já o corpo ostenta formas fálicas nos seios grandes e duros, nas nádegas avantajadas e nos saltos do sapato.

Nos parece fundamental comentar que os objetos fálicos da cultura até o século XIX eram frutos de construções e determinações relativamente espontâneos. Hoje a mídia e a propaganda não apenas "capitalizam", isto é, exploram com fins lucrativos as antigas representações fálicas da cultura, mas também produzem novas representações que funcionam como causa do desejo (Silva Jr, 2009).

A figura do empreendedor, por exemplo, desponta como o atual modelo de vida heroica. Ele resume um estilo de vida que põe no comando o detentor do falo (poder) que tem a capacidade (potência) de tomar decisões e correr riscos numa sociedade que faz da concorrência interindividual uma justa competição. Nesse contexto a noção de coletivo acaba por ficar ofuscada pelo brilho excessivo do individualismo narcísico, da necessidade diária de tomar atitudes conquistadoras/dominadoras/fálicas (Ehrenberg, 2010).

É evidente então que não se pode falar em histeria nos tempos atuais utilizando os mesmos parâmetros das histéricas freudianas. A sociedade e, principalmente, o papel da mulher nesta mudaram completamente. Antes se tinha uma mulher extremamente vinculada a figura materna, subserviente em relação ao 
homem, silenciada e reprimida em seus desejos, até mesmo como forma de garantir a soberania masculina e sua virilidade.

Hoje assistimos a diversas revoluções no campo da sexualidade, do trabalho e das relações de gênero. A própria mulher possui aspirações diferentes e encontra dificuldades distintas da sua predecessora do século XIX. Neste sentido, Maria Rita Kehl (2007) afirma que hoje a histeria apresenta-se com uma demanda confusa, dirigida ao homem, para que se faça mestre do desejo da mulher. Demanda esta que nenhum homem tem condição de atender.

Ao definir o sexual como da ordem do impróprio, Freud (1895) abriu uma nova possibilidade de interrogar a sexualidade para além do discurso biológico. Constatou, igualmente, o esforço que é feito historicamente para manter esse impróprio recalcado pela moral e pelos bons costumes. Concomitante a isso, as lutas dos movimentos feministas, libertários, LGBT etc garantem o direito à livre expressão sexual na maior parte do mundo ocidental.

Então, se a histeria fala de uma impossibilidade de se colocar em palavras aquilo que é oriundo do desejo e estreitamente relacionado à sexualidade, como pensar na sua existência em tempos de quase total liberdade sexual?

Pensamos que os interditos deixaram de se fazer presentes em relação ao sexo de forma parcial, pois vários tabus ainda persistem, de forma velada, em nossas sociedades, especialmente se pensarmos na sexualidade dos idosos. Mas outros interditos foram ganhando cada vez mais força ao longo do tempo e hoje se constituem como substitutos da mordaça que havia à expressão sexual. Falamos especialmente dos dois temas tratados no início deste artigo; o declínio da beleza (feiura) e a morte. 
Nunca antes uma sociedade lidou de forma tão superficial com estas questões como a sociedade espetacular em que vivemos. Existe um silêncio envolvendo estas temáticas, travestido ora pela banalização do fato, como ocorre em diversos momentos em que os sujeitos se deparam com a finitude da vida; fotografias self com o caixão ou com a viuva são só um exemplo da banalidade do fenómeno. Ora pela proliferação de técnicas, programas e medicamentos que garantam a perpetuação da beleza e das formas jovens.

Kehl (2007) afirmará ainda que nos tempos atuais a mulher é mais vulnerável à angústia de castração do que o homem, especialmente, quando o valor fálico estiver na beleza, na juventude, sendo ela mais afetada neste sentido do que o homem, já que a castração é uma experiência no simbólico. Onde há significantes fálicos existe angústia de castração. Como quem tem um filho e tem medo de perdêlo -, quem tem beleza e tem medo de perdê-la.

Se não se pode falar em algo que nos mobiliza, que nos constitui, que é parte fundamental de nossas existências, o afeto associado a tais representações precisa procurar outra via de expressão. Lembrando que a angústia, em Freud, nada mais é que afeto circulando livremente pelo corpo sem uma destinação específica.

No quadro atual das subjetividades espetacularizadas, alter dirigidas, performáticas e eternamente jovens a histeria aparece como uma possível resposta para explicar os modos de ser e agir de alguns sujeitos contemporâneos que levam ao paroxismo as demandas da sociedade do consumo e da imagem. É evidente que não se deseja patologizar a sociedade, pois isso é um equívoco ao qual muitos autores já incorreram e no qual a Associação de Psiquiatria Americana parece ter se especializado. Que o diga a nova versão do DSM com um acréscimo considerável de comportamentos patológicos, os quais antes eram considerados normais. 
Questionamos aqui por quais meandros a libido das mulheres maduras caminha, quando insistem violentamente em negar o seu próprio envelhecimento, recorrendo a técnicas variadas (e algumas vezes perigosas) de rejuvenescimento ou ao arsenal de psicotrópicos que servem para aliviar a angústia por algo tão natural como o passar dos anos.

\section{O corpo feminino}

A imagem de si, enquanto visão ou concepção que o indivíduo tem de si mesmo, resulta de um processo que envolve as experiências, as impressões e os sentimentos que o indivíduo vivenciou ao longo de sua existência. A maneira como cada um irá reagir ao envelhecimento não deixa de estar relacionada com as primeiras experiências de infância, que serviram de espelho estruturante e com o qual foram constituídos os alicerces da subjetividade (Vilhena, Novaes \& Rosa, 2014b).

Sibilia (2012) relembra uma propaganda veiculada no Brasil cujo slogan era "poucas coisas melhoram com o tempo" e mostrava o torso de uma mulher em diferentes momentos da sua vida, acentuando sua nítida perda de beleza. Utiliza esta perversa publicidade para interrogar com perspicácia porque tal incapacidade para melhorar com o tempo, que parece ser intrínseca a quase tudo no mundo capitalista, exceto alguns vinhos, contradiz certas crenças ainda em vigor em nossa sociedade, tais como o acúmulo de experiências e a riqueza em termos de amadurecimento que este processo acarretaria?

A dimensão da experiência e do corpo como narrativa da própria história fica perdida, quando os cuidados com o corpo senil são reduzidos às questões como vaidade ou funcionalidade, deixando de lado todos os aspectos subjetivos 
envolvidos no processo de envelhecimento; abdicando do desafio de significar seus corpos de forma diferenciada daquela em que foram pensados até muito recentemente (Vilhena \& Novaes, 2009).

A pergunta que fica é porque apenas as marcas do tempo no corpo são valorizadas? Talvez a resposta a essa questão possa ser dada através do aforismo lacaniano que "a mulher não existe" (Lacan, 1971, p. 69). Aforismo sempre problemático de ser compreendido, mas que expressa, tão somente, a ausência de uma representação para a mulher na ordem simbólica. Isso se dá pelo fato notório da mulher não possuir um falo.

Se assim o for, o corpo feminino, com todos os atributos e adereços, tornase a única prova de existência de sua portadora mascarada, na medida em que é o veículo através do qual a mulher pode forjar sua própria representação singular e diferente de todas as outras mulheres. Por essa razão, o corpo que porta tais atributos deve ser sempre belo, interessante, atraente...

No cenário social essa exigência de boa forma, beleza e atratividade ganha contornos dramáticos. A sociedade espetacularizada e midiatizada em que vivemos praticamente proíbe a exposição de corpos que destoam do ideal de belo aceito tacitamente. Para balizar este silencioso interdito, diversos são os atores sociais recrutados e complacentes.

Como afirma Debert (2004) as oposições entre "velho jovem" e "velho velho", que agora passaram a orientar categorizações médicas, são formas de estabelecer laços simbólicos entre indivíduos, criando mecanismos de diferenciação, em um mundo no qual a obliteração das fronteiras entre grupos é acompanhada da afirmação, cada vez mais pregnante, da heterogeneidade e das particularidades locais. 
A autora defende ainda que o fato dos velhos constituírem o grupo que possui a maior disponibilidade para o consumo, aliado ao imaginário (atual) da velhice como momento privilegiado para realização pessoal, e à concepção autopreservacionista do corpo, que não apenas responsabiliza os sujeitos por sua imagem, como convoca-os a conservarem seus corpos belos e "jovens" como requisito para exposição dos mesmos na sociedade, dão os contornos da socialização e reprivatização da velhice no contexto brasileiro (Vilhena, Rosa, Novaes e Martins, 2013).

A mulher de hoje é cada vez mais aquilo que o outro quer, precisa ou permite que ela seja. Pior, transformada em miragem, ela não é o que se vê, mas o que se quer ver (Novaes, 2006). Ou seja, a maioria se submete ao julgo tirânico dos discursos midiáticos e mercadológicos, buscando nos produtos e serviços espetáculo, os quais possuem sua dita eficácia endossada pela ciência, a tentativa de manterem-se belas e jovens para não serem alijadas do convívio social.

Tentativas muitas vezes frustradas, dada a impossibilidade de reverter o envelhecimento corporal; paliativas, até que se consiga a tão sonhada (e próxima?) solução definitiva; repetitivas, numa espiral tresloucada de atuações (a palavra aqui tomada em sentido clínico); performáticas, vez que criam modos de agir plásticos, despersonalizados e orientados pelo olhar do Outro e, porque não dizer, histriônicas, pois congregam todas as características anteriores e ainda almejam, ilusoriamente, manterem a relação com o objeto de desejo para sempre perdido, no caso aqui a juventude e seus estandartes.

Dito de outra maneira, levantamos aqui a hipótese de que a busca incessante pela conservação da beleza física, funciona como forma de expressão (via atuação ou passagem ao ato) da angústia causada pelas exigência sociais e impedida de ser 
colocada em palavras pelo processo de silenciamento e distanciamento em relação àquilo que é feio ou possa remeter à figura da morte. Seria uma nova forma de histeria, ainda com o afeto sendo direcionado para o corpo, no entanto, agora utilizando-se das técnicas de rejuvenescimento para modificar este corpo, coroando assim uma performance espetacular dirigida para o olhar do outro do social.

Numa recusa do lugar estereotipado de castrada, aliada à ignorância sobre o caráter simbólico do falo e da castração, a histérica procura obedecer ao que supõe atender ao desejo de um outro empenhando seu corpo, ou um representante metafórico deste, para satisfazer, eroticamente, os desejos de um Mestre que será destituído e substituído assim que lhe revelar sua falta na forma de desejo (Kehl, 2003).

\section{Concluindo e apontando caminhos}

Não desejamos colocar aqui qualquer receita sobre como as mulheres idosas devem viver a sua vida, até porque estas receitas já existem em profusão, mas nos parece interessante refletir sobre o valor atribuído aos aspectos subjetivos da mulher (experiência adquirida, maturidade afetiva, equilíbrio vivencial) na atual economia da sociedade dominada pela corpolatria. Ao longo do texto não cessamos de ressaltar este traço social problemático e gerador de estigmas. Entretanto, pensamos com Kehl (2003) que no caso de grupos reconhecidamente estigmatizados, tais como os velhos e as mulheres, a manutenção dos comportamentos sintomáticos ganha um álibi na culpabilidade do Outro do social, isentando o sujeito de qualquer responsabilização sobre aquilo que o faz sofrer.

As identidades grupais criam um campo de crenças socialmente compartilhadas que fortalecem a consistência imaginária, do ponto de vista do 
queixoso, e encobrem as manifestações do sujeito do inconsciente, sempre tão necessárias em qualquer processo de análise. Ainda assim, há que se interrogar, ao nível do sujeito, em que lugar se situa a busca pela eterna beleza e juventude. Tratase de uma tentativa saudável de melhoria da auto imagem, encaixando-se em um plano de vida repleto de pulsão ativa e mobilizadora, ou enquadra-se na repetição mortífera de um sintoma que escraviza o sujeito às demandas da sociedade?

Na hipótese desta última opção não ser a única, mas encaixar-se como uma explicação coerente para tais comportamentos, temos que considerar uma carga de sofrimento muito grande associada a estes, e nos é lícito pensar em alguma indicação que possa quebrar a cadeia de repetições, agindo como uma espécie de pontuação analítica que permita ao sujeito lidar de outra maneira com o seu afeto e com seus excessos. Preferencialmente, relançando o seu desejo em outro "lugar" que não o do aprisionamento às exigências do Outro do social. Mesmo porque, se é de modificar a direção do desejo da mulher velha que estamos falando, as nossas expectativas nesse sentido são bastante otimistas, haja visto que mudar o objeto do seu desejo é algo que a mulher aprendeu a fazer durante toda a sua vida, agindo dessa maneira em diversas situações do seu desenvolvimento.

Em psicanálise utilizamos muito o termo responsabilização. Não se trata, de forma alguma, de igualar esse termo a culpabilização. Não buscamos em uma análise culpados ou inocentes. Responsabilizar o sujeito pelo seu sofrimento é dar este a possibilidade de tornar-se, ainda que minimamente, senhor de sua vida. No processo de recordar, repetir e elaborar o analisando pode melhor dizer a sua própria história e se reposicionar em relação a esta. Ainda que seja aceitando que nada irá mudar. Mas as possibilidades de mudança estão postas, porque a vida é dele e não dos outros. Sabemos que existe um cenário social adverso para os velhos, e tanto 
mais para as mulheres velhas. No entanto, apesar disso, ou para além disso, interrogamos o que é possível ao sujeito, no caso a mulher que atinge determinada idade, fazer em relação a isso.

Talvez uma indicação que deriva da época de Sócrates possa soar bastante atual, como forma de lidar com estas exigências sociais sem tanto sofrimento. $\mathrm{O}$ cuidado de si, ou como chamavam os gregos a epiméleia heautoû, na interpretação dada por Foucault (2006) dos textos clássicos gregos, é definido da seguinte maneira "é preciso que te ocupes contigo mesmo, que não te esqueças de ti mesmo, que tenhas cuidado contigo mesmo, que sinta prazer em si mesmo". Esse conceito tem várias facetas interessantes para o nosso estudo, especialmente aquelas ligadas à preocupação com corpo próprio ou "dietética", a preparação para a vida na polis, "política" e ao aspecto psicológico ou emocional, que aqui podemos denominar de "ascetica".

A este último Foucault (1998) faz referência à ênfase deslocada das leis e amarras sociais, e posta na relação consigo, que permite não se deixar levar pelos apetites e pelos prazeres, mantendo seus sentidos num estado de tranquilidade, permanecendo livre de qualquer escravidão interna das paixões; em outras palavras seria como atingir o pleno gozo de si ou a sabedoria de si sobre si mesmo.

Podemos perceber que o cuidar de si não se limita aos cuidados com a imagem. Muito antes, fala de uma busca pelo autoconhecimento e aceitação de si próprio, trazendo equilíbrio para a vida. Este equilíbrio, inclusive, permite à pessoa que o atinge, distanciar-se da torrente das exigências sociais. Ser velha não pode ser motivo de vergonha. Menos ainda, motivo para qualquer necessária intervenção no corpo, como forma de corrigir anomalias. 
Existe um precioso capital social e emocional acumulado pelas mulheres, com o passar dos anos, o qual a atual sociedade aprendeu a desvalorizar. Essa visão massacrante em relação ao feminino precisa ser revista, é claro. Entretanto, as próprias mulheres também aderem com maior ou menor resistência a esta lógica opressiva. Talvez se elas, as detentoras deste patrimônio imaterial, o valorizarem, torne-se um pouco mais fácil que os demais atores sociais também o façam.

\section{Referências}

Adorno, T. (1948). Indústria Cultural e Sociedade. São Paulo: Paz e Terra. Ariès, P. (2000). O Homem Perante a Morte. Publicações Europa-América: Lisboa.

Ariès, P. (2003). História da Morte no Ocidente. Rio de Janeiro: Ediouro.

Baudrillard, J. (1997). A troca simbólica e a morte. São Paulo: Loyola.

Beauvoir, S. (1990). A velhice. Rio de Janeiro: Nova Fronteira.

Birman, J. (2013) A terceira idade em questão. Revista de São Paulo, 24(58), p. 50-68.

Cerqueira Filho, G. (2013). Sufoco nas alturas sobre páramo, de Guimarães rosa. Passagens. Revista Internacional de História Política e Cultura Jurídica Rio de Janeiro. 5(2), p. 168-204.

Debert, G. (2004). A Reinvenção da velhice. São Paulo. EDUSP.

Del Priore, M. (2012). Conversas sobre a história do corpo. In: Vilhena, J., Novaes, J.V. (org) Corpo pra que te quero: usos, abusos e desusos. Rio de Janeiro: Appris.

Ehrenberg, A. (2010). $O$ culto da performance: Da aventura empreendedora à depressão nervosa. Aparecida, SP: Ed. Ideias e Letras. p. 133. 
Elias, N. (2001). A solidão dos moribundos, seguido de envelhecer e morrer. Rio de Janeiro: Jorge Zahar.

Foucault, M. (1996). Microfísica do poder. Rio de Janeiro: Jorge Zahar.

Foucault, M. (1998). A história da sexualidade 2. O uso dos prazeres. Rio de Janeiro: Edições Graal.

Foucault, M. (2006). A hermenêutica do sujeito. Rio de Janeiro: Martins Fontes.

Freud, S. (1895). Estudos sobre a histeria. Edição standard brasileira das obras completas de Sigmund Freud. Rio de Janeiro: Imago.

Freud, S. (1916). Reflexões para os tempos de guerra e morte. Edição Standard Brasileira das Obras Psicológicas Completas de Sigmund Freud, vol. XIV. Rio de Janeiro: Imago, 1996.

Freud, S. (1926). Inibição, sintoma e angústia. Edição standard brasileira das obras completas de Sigmund Freud. Rio de Janeiro: Imago.

Freud, S. (1930). O mal-estar na civilização. Edição Standard Brasileira das Obras Psicológicas Completas de Sigmund Freud,vol.XXI. Rio de Janeiro, Imago.

Gonçalves, M. O. (2001). Morte e castração: um estudo psicanalítico sobre a doença terminal infantil. Revista Ciência e Profissão, Brasília, 21(1).

Gorer, G. (1995). Ni pleurs ni couronnes, précédé de Pornographie de la mort. Paris: EPEL, p. 204.

Huizinga, J. (2010). O Outono da Idade Média: estudo sobre as formas de vida e de pensamento dos séculos XIV e XV na França e nos Países Baixos. São Paulo, Cosac Naif. 
Kehl, M.R. (2007). Maria Rita Kehl: pensamento, ética e criação. Percurso, 39. Disponível

em:

<http://www2.uol.com.br/percurso/main/pcs39/39Entrevist.htm>.

Acessado em 02 de janeiro de 2015.

Kehl, M.R. (2003). Ressentimento. Clínica psicanalítica. São Paulo: Casa do Psicólogo.

Lacan, J. (1971). O seminário, livro 18: de um discurso que não fosse semblante. Rio de Janeiro: Jorge Zahar editor.

Marcuse, H. (1999). Algumas implicações sociais da tecnologia moderna. In: H. Marcuse (Org.). Tecnologia, guerra e fascismo. p. 71-104. São Paulo: Unesp.

Novaes, J.V. (2006). Sobre o sofrimento de ser feia. Mulher, beleza e regulação social. Espaço S. Revista de Investigação e Intervenção Social. Portugal.

Sibilia, P. (2011). A moral da pele lisa e a censura midiática da velhice: o corpo velho como uma imagem com falhas. In: Goldenberg, M. (org.). Corpo, envelhecimento e felicidade. Rio de Janeiro, Civilização Brasileira, 2011, p. 83-108.

Sibilia, P. (2012). O corpo velho como uma imagem com falhas: a moral da pele lisa e a censura midiática da velhice. Comunicação, mídia e consumo. 9(26), p. 83-114.

Silva Jr, N. et al. (2009) A narrativa do destino e a função identitária do corpo na modernidade. A peste, São Paulo, 1(1), p. 127-141. 
Soares, J.C., \& Dantas, M.A. (2006) Considerações sobre a morte e o morrer na hipermodernidade. Revista Estudos e Pesquisas em Psicologia. 6(2), $105-121$.

Solero-de-Campos, F., Winograd, M. (2012). Porque repensar a questão do corpo? In: Vilhena, J., Novaes, J.V. (org) Corpo pra que te quero: usos, abusos e desusos. Rio de Janeiro: Appris.

Vega, D. (2011). Manicomios SA. In: Vega et al (org) Travesias insitucionales. Buenos Aires: Lugar Editorial.

Veras, L. (2014). Aqui se Jaz, Aqui se Paga: o mercado da morte e do morrer em "tempos de imortalidade". Tese de Doutorado. Programa de Pósgraduação em Psicologia Social. Universidade do Estado do Rio de Janeiro. Rio de Janeiro.

Vilhena, J., Novaes, J.V. (2009). Un corps à la recherche d'un logement. Corps, violence et médecin. In: Masson, C. \& Desprat-Pequignot.C (orgs) Le corps contemporain: créations et faits de culture. Paris, L'Harmatan, p. 113-136.

Vilhena,J., Rosa, C.M., Novaes, J.V. \& Martins. K.H. (2013). Para além dos anos vividos. Uma leitura das categorias clínico-discursivas acerca da velhice. In: Pocinho, R., Santos, E. (orgs) Envelhecer hoje, conceitos e praticas. Curitiba: Appris, 151-175.

Vilhena, J., Novaes, J.V. \& Rosa C.M. (2014a). A sombra de um corpo que se anuncia: corpo, imagem e envelhecimento. Revista Latinoam. Psicopat. Fund., São Paulo, 17(2), 251-264. 
Vilhena, J., Novaes, J.V. \& Rosa C.M. (2014b). O que vejo no espelho? Corpo e imagem no envelhecimento feminino. In: Santos, E. et al (orgs) Metodologias. Viseu: Psicossoma.

Vovelle, M. (1983). La Mort et l'Occident: de 1300 à nous jours. Evreux: Galimard.

Vovelle, M. (1974). Mourir Autrefois. Evreux: Galimard. 


\section{Conclusão}

Após analisar todos estes diferentes aspectos do envelhecimento, suas particularidades e paradoxos, me parece impossível concluir qualquer coisa definitiva acerca da velhice sem cair em reducionismos ou simplificações. A pesquisa apenas acentuou a certeza de que o processo do envelhecimento porta singularidades que extrapolam qualquer tipo de categorização existente.

O que posso fazer é um exercício de aproximação para tentar delimitar, minimamente, algumas características dessa fase da vida, no atual contexto de nossa sociedade. Para isso é preciso buscar um ponto de ancoragem, um ponto de partida. Algo que possa emergir como estável e passível de ser analisado. Entretanto, dentre todas as incongruências e disparidades, talvez a única constante relacionada a velhice seja a mudança, ou dito de outra maneira, seu caráter mutável.

Daí vem a sublime subversão de perspectiva que Simone de Beauvoir opera ao questionar se a vida é uma marcha inexorável para a morte. Ao que a própria autora responde com a afirmativa "vida é um sistema instável no qual se perde e se reconquista o equilíbrio a cada instante; a inércia é que é o sinônimo de morte. A lei da vida é mudar (Beauvoir, 1990). Uma nova forma de olhar para o envelhecimento, de associar a velhice à vida e não à morte.

A velhice se modificou com o passar dos anos. Muitos aspectos do fenômeno de ser velho se alteraram drasticamente, como pudemos abordar em nossos artigos. Mudou o cuidado com o idoso que passou do campo privado, ao longo da idade média, para a esfera pública, quando a miséria e seus matizes passam a ser de responsabilidade do estado, e hoje está retornando ao âmbito do pessoal, através da reprivatização da velhice, em estreita relação com as cobranças feitas a todos nós, no sentido de sermos os únicos responsáveis pelo sucesso ou fracasso de nossas trajetórias. O termo sucesso aqui, bem entendido, trata-se do atingimento de uma série de metas, previamente estabelecidas pela lógica consumista e individualista da sociedade espetacular.

Segundo Costa (1985), a publicidade veicula, em relação ao sujeito que não se encaixa nos padrões difundidos, uma ideologia que o leva a um sentimento de fracasso, como se aquele que não correspondesse ao modelo de beleza, demonstrasse sua incapacidade, sua impotência diante de seu próprio corpo. Ora, 
quem não consegue agenciar nem seu próprio corpo, certamente não será o agente de sua própria vida.

É a lógica do consumo que se infiltra em todos os setores da vida, favorecendo a passagem do ideal do eu - que regula o sujeito com marcas das insígnias do Outro, conduzindo-o a uma esperança de reconhecimento - para uma outra instância que seduz e escraviza-o com sua voz, ordenando-o ao gozo ou assombrando-o com o fracasso caso não se atenda à suposta realidade (Rosa, 2005).

Mudou a relação do velho com o seu corpo, tanto na esfera da fisiologia, que trouxe avanços científicos e técnicos, responsáveis por uma maior qualidade de vida, menos sofrimento com as desregulações hormonais, com a impotência e algumas outras doenças que antes eram chamadas "doenças da idade". Quanto no plano da estética, em que a juventude eterna parece ser o modelo a ser seguido (adquirido, pois está disponível para quem tem dinheiro), independentemente da idade.

Mesmo o vestuário e os adereços não são mais os mesmos. Fotografias antigas revelam alguns signos típicos da velhice de épocas anteriores como ternos, chapéus e bengalas, no caso dos homens, e vestidos escuros e recatados ou penteados típicos, nas mulheres. Atualmente, a sobriedade e as formas mais sisudas vêm sendo substituídas por cores e modelos que expressam as possibilidades de aproveitar a velhice, a potência criativa e sexual que ainda anima os seus corpos e a perda do medo de se mostrar vivo.

A dimensão da sexualidade, da qual falei na introdução deste trabalho, e que foi retomada ao longo dos artigos, também sofreu alterações com o transcurso do tempo. Risman (2004) comenta que crenças sobre a assexualidade do idoso foram construídas desde a Idade Média, ao disseminarem que o apetite sexual desaparece com o envelhecimento, que o sexo na velhice é algo perverso ou condenável e os idosos que tentavam praticá-lo sofriam uma espécie de "autodecepção" pelas dificuldades oriundas da idade. $\mathrm{O}$ autor comenta que até bem pouco tempo, mesmo entre os idosos casados, a atividade sexual era vista como não natural e representava uma afronta à dignidade.

Hoje sabemos com Lopes (1993) que o homem é capaz de ter uma ereção em qualquer idade, da mesma maneira que a mulher consegue atingir uma lubrificação vaginal adequada e chegar ao orgasmo. As respostas sexuais de ambos os sexos ficarão prejudicadas somente perante um bloqueio físico ou psicossocial. Podemos 
considerar então que a manifestação da sexualidade não termina com a idade. Tampouco a chamada "vertigem de viver" da personagem de Clarice Lispector que aos 81 anos era "atormentada" por desejos sexuais. Por essa razão os velhos não devem acreditar que o desejo e a necessidade da manifestação sexual na velhice sejam coisas diabólicas ou um comportamento negativo em suas vidas, pensamento comum na Idade Média, que infelizmente se perpetua em alguns campos da sociedade atual.

O trabalho, antes considerado como um dos principais ritos de passagem que anunciava a entrada na velhice, agora torna-se mais um complicador para aqueles que vivem mais do que seus pais viveram. $\mathrm{O}$ estado define uma data para a garantia do direito à aposentadoria, mas as empresas do setor privado criam uma régua (não explícita) que marca a exclusão dos idosos do mercado de trabalho bem antes. A manipulação dos limites de idade para o trabalho é fruto de uma luta política que serve para definir os diferentes poderes ligados aos grupos sociais que se identificam com cada período etário.

A aposentadoria, enquanto direito fundamental, não consegue suprir as necessidades da maior parte dos que dela dependem. Além disso, o trabalho apresenta-se como um valor fundamental em nossa sociedade, destinado à produção, ao lucro e à criatividade, sendo associado à força e ao vigor dos mais jovens. Por essa razão, pessoas idosas aposentadas, não raro são desvalorizadas, vistas como inúteis, já que o trabalho do emprego formal é tomado como referência.

Sem o devido preparo para um envelhecimento ativo, os idosos podem ser vistos como um peso para suas famílias, mesmo quando mantêm atividades constantes e não dependem completamente de outrem (França, 2009). Por outro lado, temos diversas pesquisas (Vilarino e Lopes, 2008; Araújo, Nascimento Sá e Amaral, 2011) que apontam o trabalho como um dos potencializadores da saúde na velhice. Estes estudos destacam que, para muitos idosos, homens e mulheres, terem condição para o trabalho é sinônimo de saúde e qualidade de vida, considerando-se que a identidade de trabalhador o acompanha a vida inteira. Quando já não há mais possibilidade de realiza-lo, são comuns as vivências depressivas e autodepreciativas.

Aqui também é possível notar diferenças significativas na maneira como homens e mulheres vivenciam sua relação com o trabalho, a perda deste ou a sua adaptação à realidade. As mulheres encontram soluções mais criativas para tentar 
sobreviver com menos dificuldades. Acostumadas ao reino da administração doméstica, encontram nestas mesmas tarefas fontes alternativas de renda que, muitas vezes, transformam-se em empreendimentos de sucesso.

Já para os homens essa adaptação parece se dar em termos mais complexos e traumáticos. Destituídos de sua função de provedor, parece que lhes são retiradas todas as insígnias da masculinidade. Também notamos que a identidade do homem, ao longo de sua vida, permanece fortemente ligada ao pertencimento a determinada empresa. Alguns chegam a "agregar" a marca da empresa ao seu nome, tornandose o "fulano do Banco do Brasil" ou o "ciclano da IBM". Perder essa vinculação identitária é duplamente doloroso, pois soma a dimensão da perda do status social com a do reconhecimento de si mesmo enquanto partícipe de uma comunidade socialmente valorizada. Nesses casos, a busca pelo auto emprego em diferentes níveis configura-se como uma saída possível, mas longe da ideal.

Nos parece que a despeito de suas consequências positivas ou negativas, o estereótipo da velhice ligada à perda e à incapacidade tem sido substituído em nossa sociedade atual pela crença de que essa nova fase da vida pode ser também repleta de significados, onde o idoso tem a oportunidade de buscar realizações pessoais, retomar projetos que foram deixados pelo caminho e solidificar relações familiares e de amizade. Isso, é claro, para aqueles que podem pagar por tais regalias. Esse fenômeno vem ocorrendo porque as palavras com as quais nomeamos o fenômeno do envelhecimento também se modificaram, se suavizaram, numa tentativa de positivação da velhice, como se esta fase da vida fosse especial, diferente das demais (claro que todas as fases são diferentes), por ser mais rica em oportunidades de satisfação.

Nesse sentido, Lacan (1969) já informava que o laço social refere-se a relação entre os seres humanos que se sustenta no discurso e, por meio dele, assume as modalidades de época e marcas de uma cultura determinada. Discurso, por sua vez, refere-se a como se tecem as relações sociais e o que produzem como efeito. $\mathrm{O}$ discurso subsiste sem palavras, porque se trata de relações fundamentais que se sustentam da linguagem, e também sustenta a realidade, a modela sem supor o consenso por parte do sujeito. E o discurso capitalista, em particular, trabalha no sentido de estabelecer uma concepção de funcionamento social em que o indivíduo adapta-se a uma realidade dada. Privilegia não o sujeito, mas o indivíduo consumidor que, em sua dimensão de consumidor, não encontra lugar para o seu 
pathos (sofrimento), para formular demandas, remetido que fica à colagem do objeto da demanda ao objeto do consumo (Rosa, 2005).

Os rótulos empregados para desiginar o velho, na sociedade atual, são corolários de uma onda de suavização e superficialização de tudo aquilo com o qual não desejamos entrar em contato. Além disso, são mentirosos, uma vez que fazem parecer que nada de ruim existe no reino encantado da "terceira idade". Um arremedo do conceito de infância como paraíso, muito utilizado na modernidade, e com as mesmas finalidades; exigir dos velhos uma aparência de felicidade, já que não se concebe a tristeza em uma fase com tantas possibilidades de ser feliz, e a infantilização do idoso, tanto no que tange às decisões sobre seu desejo, quanto na criação de um discurso pedagógico que sabe o que é a velhice e quais melhores maneira de lidar com esta.

Não será possível pensar a significação do envelhecimento separado dos estereótipos e representações sociais que a cultura possui em relação à última fase da vida. E seria ingênuo de nossa parte dizer que todos os indivíduos se apropriam dos conceitos e figuras do imaginário partilhado de maneira idêntica. Por essa razão, a dimensão dialética entre a subjetividade e a faceta social dos homens velhos coloca-se como fundamental.

Existem assim três grandes fatores a serem levados em conta na produção das representações: a cultura, tomada tanto no sentido mais restrito, a comunicação intragrupo, entre grupos e de massas, e a inserção socioeconômica, institucional e ideológica. As condições de produção da representação afirmam a marca social das mesmas, assim como seu estatuto epistemológico marca a sua função simbólica, e os processos e estados, o seu caráter prático.

Ao formar sua representação de um objeto, o sujeito, de certa forma, o constitui, o reconstrói em seu sistema cognitivo, de modo a adequá-lo ao seu sistema de valores, o qual, por sua vez, depende de sua história e do contexto social e ideológico no qual está inserido (Moscovici, 2004). Ao se deparar com algo novo o sistema de representações fornece o balizamento para a ancoragem classificar no familiar e ali mesmo explicar aquele novo fenômeno.

Pode-se pensar em um processo de cristalização dos conceitos, ou seja o presente copia o passado e se atualiza em ato. Uma consequência da dinâmica bem conhecida do nosso psiquismo que sempre procura as informações que confirmem o seu ponto de vista negligenciando aquelas que possam enfraquecê-lo. Apoiado 
nesta dinâmica está a formação dos estereótipos arraigados existentes nas coletividades. Para o propósito deste estudo, posso me servir de vasta gama deles associados à velhice; o velho chato, o velho sovina, o moribundo, o velho safado etc. Rótulos que, não obstante o surgimento dos novos signos, acima descritos, continuam sendo utilizados, agora mais veladamente, nas relações sociais do cotidiano.

E talvez, a mudança mais significativa na linha temporal, dentre todas sobre as quais falei, consequência mesma das modificações anteriormente descritas, seja a depreciação do valor simbólico da velhice junto aos demais atores sociais. Não que a velhice tenha tido um status decisivamente positivo ao longo do tempo, mas ao acompanharmos as transformações sociais desde as civilizações mais antigas até o momento presente um quadro peculiar desenha-se ao nosso olhar. O papel do velho sempre foi ambíguo na maior parte dos períodos históricos. Algumas sociedades antigas o reverenciavam, como citamos nos artigos, o caso de algumas sociedades ágrafas, outras o depreciavam e criavam mecanismos culturalmente aceitos de higienização social, tal como o exemplo das sociedades vikings descrito por Durkheim.

Durante o período helenístico, ou a chamada Grécia Antiga a dicotomia entre Platão e Aristóteles ganha contornos de polarização quando se trata do valor concedido ao velho na sociedade grega. O discípulo de Sócrates pensa na Polis como garante da felicidade do homem, de sorte que essa felicidade só seria alcançada através do conhecimento da verdade (Havelock, 1996). Entusiasta dos potenciais da "alma humana", enquanto receptáculo precioso que acumula sabedoria, Platão coloca a velhice em alta conta nos círculos sociais, dando ao velho o lugar de detentor do conhecimento. Exorta ainda os filhos a cuidarem de seus pais, colocando suas riquezas e forças em favor destes.

Entretanto, tão bela concepção da velhice não é partilhada pela maioria dos gregos. Aristóteles será bem menos elogioso em relação ao velho, relegando muitas vezes essa classe à exclusão social completa. Coloca a sequência natural dos anos como um cabedal de mágoas, desenganos e equívocos que levam o velho ter seu raciocínio e sua firmeza nas decisões prejudicadas. A experiência é aqui descrita como um fator de involução dos homens. Apreciador das virtudes físicas, o filósofo vê no corpo macilento dos velhos mais uma prova de sua incapacidade para participar das decisões da polis (Havelock, 1983). 
Outra célebre dicotomia acerca do envelhecer trata dos famosos textos de Cícero (1997) De senectude: saber envelhecer, onde o filósofo, através de seu alter ego Catão Maior, descreveu a velhice com um bastante otimismo, enquanto a obra clássica de Norberto Bobbio, pela via do testemunho pessoal, retrata a velhice com profundo pessimismo, chegando a denomina-la como uma "longa, e não raro impaciente, espera pela morte" (Bobbio, 1997, p. 25)

Philippe Ariès (1981) traça um panorama mais alargado sobre a velhice a partir do renascimento. Ele nos informa que primeiro houve o ancião respeitável, o ancestral de cabelos de prata, de sábios e prudentes conselhos, o patriarca de experiência preciosa: o ancião do século XIX. Este senhor não era ainda muito ágil, mas também não era mais tão decrépito como o ancião dos séculos XVI e XVII. Ainda hoje resta alguma coisa deste respeito em nossos costumes. Mas, essa consideração, na realidade, não tem mais objeto, pois, em nossa época, o ancião desapareceu, sendo substituído pelos senhores ou senhoras muito bem conservados, porém nem tão veneráveis assim.

No início da era moderna, entretanto, passou a existir uma prática comum entre homens jovens que desejavam algum status social entre seus pares; o hábito de se vestirem com roupas de pessoas mais velhas e deixarem crescer a barba, de modo a ostentarem uma aparência de veneráveis jovens anciões. Tal comportamento pode ter origem naquilo que já comentamos sobre o estatuto de sabedoria dos velhos em algumas sociedades, especialmente na idade média. Aqui temos um momento de apogeu da imagem do velho aos olhos do mais moço.

Nelson Rodrigues, em sua crônica “O septuagenário nato”, descreve de forma perspicaz o fascínio que a velhice suscitava nos jovens brasileiros do início do século passado.

[...] no antigo Brasil era uma humilhação ser jovem. Só me lembro de uma meia dúzia de rapazes. Os rapazes escondiam-se, andavam rente às paredes e, para eles, a velhice era uma utopia fascinante. Por toda a parte, havia uma paisagem de velhos em flor. A palavra do velho parecia soar numa acústica de catedral. Bem me lembro de um de oitenta anos, nosso vizinho. Muitas vezes, por cima do muro, eu o espiava. Ainda por cima, hemiplégico. Pois eu achava linda essa hemiplegia. Com meus 
sete anos, gostaria de tremer como ele e de ter a mão entrevada, os dedos recurvos. E tudo mudou. Agora o importante, o patético, o sublime é ser jovem. Ninguém quer ser velho. Há uma vergonha da velhice.

Ocorre que com o advento do capitalismo mercantil, no qual o ócio passou a ser moralmente condenado, a velhice foi sendo progressivamente excluída do espaço social junto com a loucura e a delinquência, estas últimas duas sendo confinadas nos grandes hospitais (Birman, 2013). A crônica rodrigueana nos mostra que no século passado ainda resistiam alguns resquícios desta representação social venerável e digna de admiração.

No entanto, com o passar dos anos a pecha de inútil e indigno foi dominando o cenário social. Assistimos a um reforçamento da imagem negativa da velhice, sobretudo associada a fragilidade biopsíquica e a decadência. Consequência da corpolatria vigente, da valorização da força e da capacidade de produção. Tais conceitos ainda se alargariam para outras facetas da velhice e acompanhariam os velhos até as duas últimas décadas do século passado, quando o capitalismo, sempre ele, descobre na população idosa um nicho de compradores potenciais.

Bauman (1999) dirá que a nossa sociedade tornou-se uma "sociedade de consumo", enquanto a sociedade moderna nas suas camadas fundadoras, na sua fase industrial, era uma "sociedade de produtores". Aquela velha sociedade moderna engajava seus membros primordialmente como produtores e soldados, daí a desvalorização daqueles que não possuem a força necessária para lutar ou produzir. Entretanto, a maneira como a sociedade atual molda seus membros é ditada primeiro e acima de tudo pelo dever de desempenhar o papel de consumidor. E nada melhor do que o dinheiro para aproximar universos tão distintos, como o velho e o jovem.

Estas modificações nos contextos e na relação do Outro social com a velhice trazem profundos reflexos na vida dos idosos, pois a velhice é uma construção fundamentalmente alteritária. Em um de seus últimos textos Sartre (1992) analisa de maneira precisa essa faceta do envelhecimento ao afirmar que "a velhice é uma realidade minha que os outros sentem", são os outros que o veem e dizem "este velho senhor"; o filósofo então conclui de forma brilhante que "os outros é que são a minha velhice" (p. 37). 
Ironicamente, todas essas particularidades e diferenças existentes em relação ao ser velho, costumam ser eclipsadas e pasteurizadas, reduzidas a uma única e taxativa expressão "é da velhice". Como se existisse mesmo uma velhice prototípica e generalizante. Outrossim, se pensarmos com Lacan (1998) que um significante representa o sujeito para outro significante, como fica a subjetividade dos velhos, sua representação identitária, nesse contexto em que os significantes que o distinguem, ou estão em constante mutação, ou não o representam corretamente? Me lembra o episódio, narrado pelo próprio Lacan, em que o homem está de frente com um louva-deus gigante e usa uma máscara que ele não sabe bem qual é. A angústia sentida por este homem que não sabe o que representa para o Outro assustador e ameaçador é palpável e difícil de ser significada; angústia de não saber o que significa.

A outra face da angústia, descrita em nossos artigos, é aquela que remete ao desamparo fundamental, o qual se torna cada vez mais presente na contemporaneidade. Fruto da ausência de fiadores da existência, cujas bases se assentam, hoje, em miragens de felicidade plena e na possibilidade de comprar a satisfação máxima e irrefreável do gozo absoluto do Outro. Apesar do progressivo afrouxamento do controle social ao fluxo pulsional, ocorrido na civilização ocidental nas últimas décadas do século passado, o que se viu não foi uma diminuição da angústia, tal como acreditava Freud, outrossim uma manutenção desta em nível insuportável, ou mesmo sua exacerbação em diversas patologias modernas.

Isso se dá pela subversão da noção de busca da felicidade na contemporaneidade, capitaneada pela massificação do consumo. O que o consumidor atual espera é que seu produto, ou objeto de consumo, lhe dê a máxima satisfação (aquela satisfação idealizada do gozo incestuoso) e pelo maior tempo possível. E quando isso não acontece a solução é buscar na próxima mercadoria, produto ou quimera essa tão sonhada realização. Aqui faz todo sentido a formula lacaniana de desejar para sentir falta. Buscar o objeto $a$ como forma de escapar da angústia que nos acomete a todos. Mesmo porque uma sociedade que se alimenta do livre fluxo de energia, como é a de consumo, tem por efeito uma diminuição da capacidade de representação do sujeito.

Nesse contexto, o reconhecimento subjetivo entra em cena como fator fundamental na valorização de si, dada através do outro, que deve sempre ocorrer 
de forma recíproca. A necessidade da realização deste ato afeta o funcionamento social, assim como as lutas políticas, pois estas implicam a tentativa de um grupo de serem reconhecidos e valorizados por outros grupos.

Tal como a confiança no afeto do outro é fundamental para a criança se sentir no direito de se manifestar, a segurança de ser merecedor de respeito do outro leva ao respeito de si próprio. Este fenômeno, entretanto, não costuma ser notado em sua existência, quando está presente e ocorrendo nas relações sociais. Ele só é percebido em sua forma negativa, ou seja, quando é negado o auto respeito.

A pergunta que fica é: que tipo alteridade nós, enquanto sociedade, estamos representando hoje? Se somarmos o descaso com os velhos mais pobres, o afastamento dos mais jovens (especialmente as crianças) do convívio com avós, os maus tratos no âmbito familiar e, principalmente, institucional, a acessibilidade quase inexistente nas grandes cidades, o despreparo (e o desprezo) da maioria dos funcionários públicos e privados no atendimento a aposentados e pessoas com mais de 65 anos e tantas outras formas de violência real e simbólica, qual o verdadeiro lugar deste sujeito em nossa sociedade?

Trata-se do idoso, termo legal, que remete ao Estatuto do Idoso, aprovado há cerca de dez anos, indivíduo possuidor de direitos civis e sociais? Trata-se do aposentado, marcado pelo estigma da desocupação, que luta para sobreviver com um salário insuficiente, tentando aniquilar o seu desejo de ser útil, ou buscando vias alternativas para sua força de trabalho desprezada? Trata-se consumidor de produtos e serviços especiais para a "terceira idade", cuja vida é melhor que a dos dois primeiros, ainda que o dinheiro não possa comprar afeto genuíno? Ou podemos falar de um sujeito às voltas com o fantasma redivivo da castração, assombrando-o em cada uma das perdas, que luta para significar tudo o que a vida, impiedosamente, tomou?

Talvez seja interessante retomar o que foi dito com Green (1988) que para poder dizer sim a si mesmo é preciso poder dizer não ao objeto. É através deste ato de dizer não que os limites psíquicos podem se estabelecer, favorecendo a capacidade de representação e a constituição subjetiva. $O$ homem velho pode enriquecer o seu mundo interno com as representações das coisas que ficaram perdidas ao longo do processo de envelhecimento, recusando-se a aceitar as exigências massacrantes da sociedade atual para poder levar uma vida mais adequada às suas pretensões e condições. 
Por exemplo, através da jovialidade tanto moço quanto o velho podem se reencontrar, e sentir a mesma saudade que em vida se sente da vida, saudades das partes corporais e de partes espirituais, que morrem ao longo da existência. Recuperando estas partes via simbolização e historicização das faltas, para então poderem reinventar novas formas de ser no mundo, novos lugares subjetivos. Relançar o próprio desejo em lugares menos áridos e mais frutíferos.

Entretanto, antes que se tome uma vertente de análise notadamente clínica precisamos concordar com Botomé (2010) quando propõe a seguinte questão: a quem devemos "tratar e mudar": o homem que sofre ou as condições que o fazem sofrer ou produziram seu sofrimento? Não seria o papel da sociedade promover uma maior inclusão dos velhos e criar condições para um final de existência mais digno?

Como dissemos em outro texto, alguns sujeitos ainda buscam um mundo, onde cabe vários mundos, encontrar as forças ativas, afirmadoras da vida contidas em sonhos e numa vida que ainda está por vir (Vilhena, Rosa, Ibrahim e Petrelli, 2012). Na perspectiva apontada por Nietzsche (1978), força plástica criadora contida nos sonhos desta população, capaz de criar novas formas de existência. A chamada Vontade de Potência demonstra a capacidade que alguns seres humanos possuem de, a partir da exclusão, serem capazes de criar cadeias discursivas diferentes, vivenciadas em seu mundo extra-muros.

Ou como disse o poeta Mario Quintana: "O tempo é um ponto de vista. Velho é quem é um dia mais velho que a gente... Idades só há duas: ou se está vivo ou morto". Mesmo porque, independentemente da idade, "o passado não reconhece o seu lugar: está sempre presente" e todos temos de nos haver com isso. 


\section{6 - Referências Bibliográficas}

ADORNO, T. Indústria Cultural e Sociedade. São Paulo: Paz e Terra. 1948.

ARAÚJO, L.; NASCIMENTO SÁ, E.C.; AMARAL, E.B. Corpo e Velhice: Um Estudo das Representações Sociais entre Homens Idosos. Psicologia: ciência e profissão, 31 (3), 468-481. 2011.

ARAUJO, M.M.T; SILVA, M.J.P A comunicação com o paciente em cuidados paliativos: valorizando a alegria e o otimismo. Revista da Escola de Enfermagem da USP, São Paulo, v. 41, n. 4, 668-674. 2007.

ARIÈS, P. História da Morte no Ocidente. Rio de Janeiro: Ediouro. 2003.

ARIÈS, P. O Homem Perante a Morte. Publicações Europa-América: Lisboa. 2000.

ARIÉS, P. História social da criança e da família. Rio de Janeiro: Ed. Guanabara. 1981.

BACHELARD, G. Filosofia do novo espírito científico. Lisboa: Ed. Presença. 1972.

BAUMAN, Z. O Mal-estar na Pós-Modernidade. Rio de Janeiro: Jorge Zahar. 1998.

BAUMAN, Z. Identidade. Rio de Janeiro: Zahar. 2005.

BAUMAN, Z. 44 cartas do mundo líquido moderno. Rio de Janeiro: Zahar. 2011.

BAUDRILLARD, J. A troca simbólica e a morte. São Paulo: Loyola. 1997.

BEAUVOIR, S. A velhice. Rio de Janeiro: Nova Fronteira. 1990.

BENJAMIN, W. (1936). O Narrador. In: Obras escolhidas 1. São Paulo: Brasiliense. 
BENJAMIN, W. (1933). Experiência e pobreza. In: Obras escolhidas 1. São Paulo: Brasiliense.

BERLINCK, M. T. Psicopatologia Fundamental. São Paulo: Escuta. 2000.

BEZERRA JR, B. A psiquiatria e a gestão tecnológica do bem-estar. Ser feliz hoje: reflexões sobre o imperativo da felicidade. Rio de Janeiro: Editora FGV. 2010.

BION, W. R. (1962) Learning from experience. London: Heinemann.

BIRMAN, J. A terceira idade em questão. Revista de São Paulo, 24(58), 50-68. 2013.

BOBBIO, N. O Tempo da Memória: De Senectute e outros escritos autobiográficos. Rio de Janeiro: Editora Campos Ltda., 1997.

BOIA, L. Quand les centenaires seront jeunes: l'imaginaire de la longévité de l'Antiquité à nos jours. Belles lettres. 2006.

BORGES, J. L. O livro de areia. São Paulo: Media Fashion, 104 p. 2012.

BOTOMÉ, S.P. A quem nós, psicólogos, servimos de fato?. In: YAMAMOTO, O.H.; COSTA, A.L. F.(orgs.) Escritos sobre a profissão de psicólogo no Brasil. Natal: EDUFRN, 2010.

BRUM, E. O olho da rua: uma repórter em busca da literatura da vida real. São Paulo: Globo. 2008.

CABRAL, M. Ganhos e perdas. Rev. Página 22, Ed. 70. 2012. Recuperado em 20 abril de 2013 de <http://pagina22.com.br/index.php/2012/12/ganhas-e-perdas/> .

CERQUEIRA FILHO, G. Sufoco nas alturas sobre páramo, de Guimarães rosa. Passagens. Revista Internacional de História Política e Cultura Jurídica Rio de Janeiro. 5(2), p. 168-204. 2013.

CERTEAU, M. A invenção do cotidiano. Petrópolis: Vozes. 1994. 
CÌCERO, M. T. Saber Envelhecer / A Amizade. Porto Alegre: L\&PM Editores, 1997.

CINQUEPALMI, J. V. Você pode ser imortal. Super Interessante, 14. 2010.

CORREA, M.R. (2009) Cartografias do envelhecimento na contemporaneidade. São Paulo: Cultura acadêmica.

COSTA, J.F. Violência e Psicanálise, Rio de Janeiro, Ed. Graal. 1985.

DEBERT, G. A Reinvenção da velhice. São Paulo. EDUSP. 2004.

DEL PRIORE, M. Conversas sobre a história do corpo. In: Vilhena, J., Novaes, J.V. (org) Corpo pra que te quero: usos, abusos e desusos. Rio de Janeiro: Appris. 2012.

DOLTO, F. Sexualidade feminina. Libido, erotismo, frigidez. São Paulo: Martins Fontes. 1984.

DOLTO, F. \& NASIO, J. D. A criança do espelho. Porto Alegre: Artes Médicas. 1991.

DURKHEIM, E. Suicide: a study in sociology. The Free Press. 1997.

EHRENBERG. A. (1998) La Fatiga de Ser Uno Mismo: Depresión y Sociedad. Buenos Aires: Ediciones Nueva Visión.

EHRENBERG, A. O sujeito CEREBRAL. Psicologia clinica, 21(1), 187-213. 2009.

EHRENBERG, A. O culto da performance: Da aventura empreendedora à depressão nervosa. Aparecida, SP: Ed. Ideias e Letras. p. 133. 2010.

ELIAS, N. A solidão dos moribundos, seguido de envelhecer e morrer. Rio de Janeiro: Jorge Zahar. 2001. 
FEATHERSTONE, M., \& HEPWORTH, M. Images of ageing: cultural representations of later life. The Cambridge handbook of age and ageing, 354362. 2005.

FERENCZI, S. Contraindicações da técnica ativa. In Obras completas III. São Paulo: Martins Fontes. 1926.

FOUCAULT, M. Microfísica do poder. Rio de Janeiro: Jorge Zahar. 1996.

FOUCAULT, M. A história da sexualidade 2. O uso dos prazeres. Rio de Janeiro: Edições Graal. 1998.

FOUCAUlT, M. A hermenêutica do sujeito. Rio de Janeiro: Martins Fontes. 2006.

FRAIMAM, A. P. Coisas da Idade. $2^{a}$ ed, São Paulo, Hermes. 1991.

FRANÇA, L. H. A longevidade e suas consequências para o mundo do trabalho. Sinais Sociais, SESC, Departamento Nacional, 10 (4), 98-121. 2009.

FREIRE FILHO, J. A felicidade na era de sua reprodutibilidade científica: construindo" pessoas cronicamente felizes. In: FREIRE FILHO, J. (org.) Ser Feliz Hoje: reflexões sobre o imperativo da felicidade. Rio de Janeiro: FGV, 2010.

FREITAS, M. C.; QUEIROZ, T. A.; SOUSA, J. A. V. O significado da velhice e da experiência de envelhecer para os idosos. Revista Escola de Enfermagem USP; 44(2):407-12, 2010. Disponível em <www.ee.usp.br/reeusp/> Acessado em 03 de jan de 2013.

FRENK-WESTHEIM, M. Y mil aventuras. Siglo XXI. 2001.

FREUD, S. Estudos sobre a histeria. Edição standard brasileira das obras completas de Sigmund Freud. vol. I. 1895. Rio de Janeiro: Imago. 2000. 
FREUD, S. Projeto para uma psicologia científica. In: Edição standard brasileira das obras psicológicas completas de Sigmund Freud, vol. I. 1895. Rio de Janeiro: Imago, 2000.

FREUD, S. Sobre o Narcisismo: uma introdução. In Edição standard brasileira das obras psicológicas completas de Sigmund Freud. vol. XIV. 1914. Rio de Janeiro, Imago. 2000.

FREUD, S. Sobre a transitoriedade. Edição standard brasileira das obras psicológicas completas de Sigmund Freud, vol. XIV. 1915. Rio de Janeiro: Imago. 2000.

FREUD, S. L. Luto e melancolia. Edição Standard Brasileira das Obras Psicológicas Completas de Sigmund Freud, vol. XIV. 1915. Rio de Janeiro: Imago. 2000.

FREUD, S. Reflexões para os tempos de guerra e morte. Edição Standard Brasileira das Obras Psicológicas Completas de Sigmund Freud. vol. XIV. 1916. Rio de Janeiro: Imago, 2000.

FREUD, S. Luto e melancolia. In: Edição standard brasileira das obras psicológicas completas de Sigmund Freud. vol. XIV. 1917. Rio de Janeiro, Imago. 2000.

FREUD, S. Para além do princípio do prazer. In: Edição standard brasileira das obras psicológicas completas de Sigmund Freud. vol. XVIII. 1920. Rio de Janeiro, Imago. 2000.

FREUD, S. O ego e o Id e outros trabalhos. Edição Standard Brasileira das Obras Psicológicas Completas de Sigmund Freud, vol. XIX. 1923. Rio de Janeiro: Imago, 2000.

FREUD, S. O problema econômico do masoquismo. In: Edição standard brasileira das obras psicológicas completas de Sigmund Freud. vol. XIX. 1924. Rio de Janeiro, Imago. 2000. 
FREUD, S. A negativa. In: Edição standard brasileira das obras psicológicas completas de Sigmund Freud. vol. XIX. 1925. Rio de Janeiro, Imago. 2000.

FREUD, S. Inibição, sintoma e angústia. Edição standard brasileira das obras completas de Sigmund Freud. vol. XVII. 1926. Rio de Janeiro: Imago. 2000.

FREUD, S. O mal-estar na civilização. Edição Standard Brasileira das Obras Psicológicas Completas de Sigmund Freud. vol. XXI. 1930. Rio de Janeiro, Imago. 2000.

FREUD, S. Moisés e o monoteísmo. In: Edição Standard Brasileira das Obras Psicológicas Completas de Sigmund Freud. vol. XXIII. 1937. Rio de Janeiro, Imago. 2000.

GABBAY, R. Considerações sobre psicanálise com idosos. Anais da Primeira Jornada de Psicanálise com Idosos e suas Interseções, Rio de Janeiro: Escola Brasileira de Psicanálise Movimento Freudiano. p. 31-39. 1999.

GARCIA, C. A.; DAMOUS, I. O silêncio no psiquismo: uma manifestação do trabalho do negativo patológico. Caderno de Psicanálise-CPRJ, Rio de Janeiro, ano 31, n. 22, p. 105-115. 2009.

GARCIA-ROZA, L.A. Introdução à Metapsicologia Freudiana 1. São Paulo: Zahar. 2001.

GEBRAN, P. Velhos nas sociedades ágrafas. Anais da Primeira Jornada de Psicanálise com Idosos e suas Interseções, Rio de Janeiro: EBP, 20-30. 1999.

GEERTZ, C. Representações simbólicas. Rio de Janeiro: Zahar. 1996.

GIL, J. Metamorfoses do corpo. In: Portugal, hoje: o medo de existir. Lisboa, Relógio d'Água. 1997.

GOLDFARB, D. C. Corpo, tempo e envelhecimento. São Paulo: Casa do Psicólogo. 1998. 
GONÇALVES, M. O. Morte e castração: um estudo psicanalítico sobre a doença terminal infantil. Revista Psicologia, Ciência e Profissão, Brasília, 21(1). 2001.

GORER, G. Ni pleurs ni couronnes, précédé de Pornographie de la mort. Paris: EPEL, p. 204. 1995.

GREEN, A. A mãe morta. In: Narcisismo de vida, narcisismo de morte. São Paulo: Editora Escuta, p. 247-282. 1980.

GREEN, A. O trabalho do negativo. Porto Alegre: Artmed, 1988.

GROMANN, R. M. G. A política do erotismo na maturidade feminina: um estudo sobre as relações entre os estados hipocondríacos e melancólicos. Rev. Latinoam. Psicopat. Fund., X, 2, 203-218 2007.

HAVELOCK, E. Prefácio a Platão. Campinas, SP: Papirus. 1996.

HEIDEGGER, M. Ser e Tempo. Petrópolis: Ed. Vozes. 1988.

HUSSEY, T. Reflections. Hussey Photography. Dallas, fevereiro, 2014. Recuperado em 10 julho de 2014,de: <http://www.tomhussey.com/SERIES/Reflections/1/thumbs>.

HUIZINGA, J. O Outono da Idade Média: estudo sobre as formas de vida e de pensamento dos séculos XIV e XV na França e nos Países Baixos. São Paulo, Cosac Naif. 2010.

IBGE. Censo Demográfico 2010. Disponível em: <http://www.censo2010.ibge.gov.br>.

KEHL, M. R. Função Fraterna. S. Paulo: Relume Dumara. 2000.

KEHL, M.R. Maria Rita Kehl: pensamento, ética e criação. Percurso, 39. 2007. Disponível em: <http://www2.uol.com.br/percurso/main/pcs39/39Entrevist.htm>. Acessado em 02 de janeiro de 2015.

KEHL, M.R. Ressentimento. Clínica psicanalítica. 2003. São Paulo: Casa do Psicólogo. 
KRISTEVA, J. Les Nouvelles Maladies de L’Âme. Paris: Fayard. 1993.

LACAN, J. O seminário, livro 2: o eu na teoria de Freud e na técnica da psicanálise. Rio de Janeiro: Jorge Zahar Editor. 1954.

LACAN, J. A significação do falo. Escritos. Rio de Janeiro: Nova Fronteira. 1958.

LACAN, J. Seminário 17 - o avesso da psicanálise. Rio de Janeiro: Jorge Zahar Jorge Zahar Editor, 1969.

LACAN, J. O seminário, livro 18: de um discurso que não fosse semblante. Rio de Janeiro: Jorge Zahar editor. 1971.

LACAN, J. Subversão do sujeito e dialética do desejo no inconsciente freudiano. In: Escritos. Rio de Janeiro: Jorge Zahar Editor. 1998.

LACAN, J. Função e campo da palavra e da linguagem em psicanálise In: Escritos. Rio de Janeiro: Jorge Zahar Editor. 1998.

LATOUR, B. How to talk about the body? The normative dimension of sciences study. Artigos online de Bruno Latour. 2002. Disponível em: <www.ensmp.fr/ latour>. Acessado em 16 de março de 2015.

LÉVI-STRAUSS, C. Introdução: a obra de Marcel Mauss. In: MAUSS, M. Sociologia e antropologia. São Paulo: EPU/EDUSP. p. 1-36. 1974.

LISPECTOR, C. Água Viva. 13º edição. Rio de Janeiro: Francisco Alves. 1994.

LOPES, G. Sexualidade Humana. 2a edição. Rio de Janeiro: Medsi. 1993.

KAMPER, D. "Corpo" IN: WÜLF, Christopher (ed.). Cosmo, Corpo, Cultura; Enciclopedia Antropologica. Milão: Bruno Mondadori. 2002.

MARCUSE, H. Algumas implicações sociais da tecnologia moderna. In: H. Marcuse (Org.). Tecnologia, guerra e fascismo. p. 71-104. São Paulo: Unesp. 1999. 
MAUSS, M. A expressão obrigatória dos sentimentos. In: Mauss, M. São Paulo: Ática, p. 147-53. 1921.

MEIRELES, C. Obra Poética. Rio de Janeiro: José Aguilar. 1958.

MONTERROSO, A. A ovelha negra e outras fábulas. São Paulo: Cosac Naif. 2014.

MOSCOVICI, S. Representações sociais: investigações em psicologia social. Petrópolis: Vozes. 2004.

MENDES, L. C.; GARCIA, C. A. Os destinos do trabalho do negativo nas patologias limítrofes. Psicologia em Revista, v. 18, n. 2, p. 277-292. 2012.

MESSY, J. A pessoa idosa não existe. São Paulo: Aleph. 1992.

MILLOT, C. Nobodaddy, a histeria no século. Rio de Janeiro: Jorge Zahar. 1988.

NIETZSCHE, F. Assim falou Zaratustra. São Paulo: Hemus. 1978.

NOVAES, J.V. Sobre o sofrimento de ser feia. Mulher, beleza e regulação social. Espaço S. Revista de Investigação e Intervenção Social. Portugal. 2006.

PEREIRA, M.E.C. Pânico e desamparo. São Paulo: Escuta. 1999.

PERES, M. R.S. O homem e as marcas do tempo. In: Monteiro, A. (org) Dimensões do envelhecer. Rio de Janeiro: Revinter. 2004.

QUINET, A. A descoberta do inconsciente. Do desejo ao sintoma. Rio de Janeiro: Jorge Zahar Editor. 2000.

OLIVEIRA, R.D. A liberdade comanda. Coluna de Opinião do Jornal "O Globo". Disponível em http://oglobo.globo.com/opiniao/a-liberdade-comanda15722048\#ixzz3VoKf571Q acessado em 28 de março de 2015.

RISMAN, A. Sexualidade e Terceira Idade: uma visão histórico-cultural. Textos Envelhecimento. vol.8, n.1, p. 89-115. 2005.

ROTH, P. Homem comum. São Paulo: Cia das Letras. 2007. 
ROSA, C.M. Silêncio, exclusão e morte: o trabalho do negativo na velhice. Polêm!ca, v. 13, n.1. p. 923-944. 2014.

ROSA, C. M.; ZAMORA, M. H. Usos da internet: algumas reflexões éticopolíticas. Revista Polêm!ca, v. 11, n. 4. 2012.

ROSA, M. D. "Gozo e política na psicanálise: a toxicomania como emblemática dos impasses do sujeito contemporâneo”, In: ROSA, M.D. Trauma e Psicanálise. São Paulo: Ed. Pulsional. 2005.

ROUSSILLON, R. A capacidade de criar e a exigência de criar. Jornal de Psicanálise, v. 43(79), p. 237-256. 2010.

ROUSSILLON, R. Le processus de symbolisationetsesétapes. In: Chouvier, B. (ed), Matière à symbolisation, C.H. 1027 Lonay, Delachaux et Niestlé, 2000. Disponível em http://psycho.univ-lyon2.fr/sites/psycho/IMG/pdf/doc-226.pdf acessado em 11 de junho de 2013.

SAKAMOTO, L. Caso Babilônia: Promovendo a barbárie em nome de Deus. Blog do Sakamoto. Disponível em http://blogdosakamoto.blogosfera.uol.com.br/2015/03/23/caso-babiloniapromovendo-a-barbarie-em-nome-de-deus/ acessado em 25 de março de 2015.

SARAMAGO, J. As intermitências da morte. Leya. 2011.

SARTRE, J. A esperança agora. Rio de Janeiro: Editora Nova Fronteira, 1992.

SAWAIA, B. B. Dimensão ético-afetiva do adoecer da classe trabalhadora. In S. T. M. Lane \& B. B. Sawaia (Orgs.). Novas veredas da psicologia social. p. 157-168. São Paulo: Brasiliense. 2006.

SHAKESPEARE, W. Henrique V. São Paulo: L\&PM EDITORES. 1599.

SIBILIA, P. O show do eu: a intimidade como espetáculo. Nova Fronteira. 2008. 
SIBILIA, P. A moral da pele lisa e a censura midiática da velhice: o corpo velho como uma imagem com falhas. In: Goldenberg, M. (org.). Corpo, envelhecimento e felicidade. Rio de Janeiro, Civilização Brasileira, 2011, p. 83-108. 2011.

SIBILIA, P. O corpo velho como uma imagem com falhas: a moral da pele lisa e a censura midiática da velhice. Comunicação, mídia e consumo. 9(26), p. 83-114. 2012.

SILVA, C.A. Proust, Bergson, Benjamin: breve nota sobre o tempo, a duração e a modernidade na "busca do tempo perdido". Jornal Opção, Goiânia, 29 de maio de 2011. 2014. Recuperado em 10 maio de 2014, de: <http://www.jornalopcao.com.br/posts/opcao-cultural/proust-bergson-benjaminbreve-nota-sobre-o-tempo-a-duracao-e-a-modernidade-na-busca-do-tempoperdido>.

SILVA JR, N. et al. A narrativa do destino e a função identitária do corpo na modernidade. A peste, São Paulo, 1(1), p. 127-141. 2009.

SOARES, J.C., \& DANTAS, M.A. Considerações sobre a morte e o morrer na hipermodernidade. Revista Estudos e Pesquisas em Psicologia. 6(2), 105-121. 2006.

SOLERO-DE-CAMPOS, F., WINOGRAD, M. Porque repensar a questão do corpo? In: VILHENA, J., NOVAES, J.V. (org) Corpo pra que te quero: usos, abusos e desusos. Rio de Janeiro: Appris. 2012.

TOLSTOI, L. A morte de Ivan Ilitch. Porto Alegre: L\&PM. 1997.

TURKLE, S. The Second Self: Computers and the Human Spirit. New York: Simon \& Schuster, Inc. 1985.

URRIBARRI, F. André Green: paixão clínica, pensamento complexo. Contemporânea - Psicanálise e Transdisciplinaridade, Porto Alegre, n.10, p. 1143. 2010.

VEGA, D. Manicomios SA. In: Vega et al (org) Travesias insitucionales. Buenos Aires: Lugar Editorial. 2011. 
VERAS, L. Aqui se Jaz, Aqui se Paga: o mercado da morte e do morrer em "tempos de imortalidade". Tese de Doutorado. Programa de Pós-graduação em Psicologia Social. Universidade do Estado do Rio de Janeiro. Rio de Janeiro. 2014.

VIEIRA, E. B. Manual de Gerontologia. Rui de janeiro: Revinter. 1996.

VIEIRA, M. A. Psicanálise e psicoterapia. Latusa, Rio de Janeiro, v. 6, p. 103-114, 2001.

VILARINO, M. A. M.; LOPES, M. J. M. Envelhecimento e saúde nas palavras de idosos de Porto Alegre. Estudos Interdisciplinares do Envelhecimento, 13(1), 63-77. 2008.

VILHENA, J., NOVAES, J.V. Un corps à la recherche d'un logement. Corps, violence et médecin. In: Masson, C. \& Desprat-Pequignot.C (orgs) Les corps contemporain: créations et faits de culture. Paris, L’Harmatan, p. 113-136. 2009.

VILHENA, J. (2012) Repensando a velhice em tempos sombrios. Pocinho, R., Santos, E. \& Gaspar, J.P., (orgs) Envelhecer em tempos de crise: Respostas Sociais. Coimbra. Legis Editora. p. 11-28.

VILHENA, J.; ROSA, C.M.; IBRAHIM, E.\&PETRELLI, P. Corpos invisíveis. Violência e dor. In: Vilhena, J. \& Novaes, J.V. (org) Corpo para que te quero? Usos, abusos e desusos. Rio de Janeiro/Curitiba. Eds PUC/APPRIS. 2012.

VILHENA, J.; ROSA, C. M.; NOVAES, J. V. Para além dos anos vividos. Uma leitura das categorias clínico-discursivas acerca da velhice. In: Pocinho, R., Santos, E. (orgs) Envelhecer hoje, conceitos e práticas. Coimbra, Legis. 2013.

VILHENA, J., NOVAES, J.V., ROSA, C.M. O que vejo no espelho? Corpo, imagem e envelhecimento feminino. In: Pocinho, R., Silva, A. A., Santos, E., Vilhena, J. (Orgs.) Metodologias de Investigação: Estudos sobre o Envelhecimento. Viseu: Psicosoma. 2014.

VILHENA, J., NOVAES, J.V. \& ROSA C.M. A sombra de um corpo que se anuncia: corpo, imagem e envelhecimento. Revista Latinoam. Psicopat. Fund., São Paulo, 17(2), 251-264. 2014. 
VILHENA, J.; ROSA, C. M.; NOVAES, J. V. Narrando dores. A tatuagem como discurso. Cadernos de Psicanálise do CPRJ. Prelo.

VILHENA, J.; ROSA, C. M. Envelhecimento e seus possíveis destinos. Uma reflexão acerca do trabalho do negativo. Revista do Tempo Psicanalítico. 47(1), jun. 2015. Prelo.

VOVELLE, M. La Mort et l'Occident: de 1300 à nous jours. Evreux: Galimard. 1983.

VOVELLE, M. Mourir Autrefois. Evreux: Galimard. 1974.

WOOLF, V. A Dama no Espelho: Reflexo e Reflexão. Contos Completos. São Paulo. Cosac Naif. 2005.

ZORNIG, S. M. A. A corporeidade na clínica: algumas observações sobre os primórdios do psiquismo. Rev. do Tempo Psicanalítico, v.40, n.2, p. 327-337. 2008. 


\section{Anexos}

\section{Anexo 1 - Velha infância}

\section{Artigo publicado pela Plataforma Barômetro Social.}

Autores: Carlos Mendes Rosa

Recebido em: 06/02/2015

Aceito em: 21/03/2015

As referências bibliográficas foram mantidas no formato original da revista.

Afonso sempre adorou sua infância.

Sua vida pode se resumir em uma palavra; “brincar”. Não há nada atualmente que venha lhe preocupar. Lembra-se de ter escutado alguém afirmar que "crianças não tem preocupação, só tem coisas boas para pensar e lembrar”. E que delícia era a lembrança daquele passeio com sua mãe na cachoeira, quando viu o arco-íris se formando na água pela primeira vez. O primeiro presente que se recorda de ter ganhado; uma sacola com bolinhas de gude dadas pelo seu pai. E aquela amiguinha que conheceu na igreja, Sandra - a menina de cabelos encaracolados, com quem passara muitas tardes comendo bolo de chuva e contando nuvens. Pena que não a via mais, pois ela mudara de cidade.

Afonso não tem que ir a escola, por isso passa horas em frente à televisão.

Algo curioso dessa época da vida é que a fantasia se mudou para uma casa bem próxima à residência da sua amiga realidade. Elas passam a conviver mais intimamente; se encontram várias vezes ao longo do dia. É nesses momentos que os personagens dos programas de televisão vêm para a sala da casa de Afonso brincar e conversar com ele. Alias, são as melhores companhias que ele poderia ter, bem diferentes dos outros moradores regulares da sua casa. Pois enquanto os primeiros são sempre alegres, divertidos, entendem tudo o que ele fala e estão sempre disponíveis, os últimos parecem carregar o mundo nas costas, raras vezes dão um sorriso e nunca têm tempo para conversar com ele.

Nos dias em que está mais compenetrado, olha as misérias do mundo da janela de sua TV e fica pensando em planos para mudar o rumo das coisas... Mas isso só caso ele agüente estar entre os adultos. Entre um programa e outro adora "desenhar" nos papéis que ficam sobre a mesa da sala de estar. 
- Não sei por que você faz esses rabiscos todos os dias - lhe diz Jucélia - a empregada - que não obstante o mau humor vive lhe trazendo canetinhas coloridas.

A mesma Jucélia, em meio aos afazeres domésticos, observa Afonso com rabo de olho para prevenir que ele apronte alguma. Chama a sua atenção o fato dele ficar sentado, imerso em seus próprios pensamentos, alheio de todo o resto do mundo. E o mais curioso, pensa ela, é que ele fica lá com uma carinha boa, “deve de estar feliz o danadinho..."

É verdade que Afonso dá muito trabalho em casa. Sempre ouve as pessoas reclamarem das peripécias que ele vive fazendo. Essa semana mesmo, resolveu sair sozinho para "dar uma volta" e pôs a casa inteira atrás dele pelas ruas do bairro. "Não sou um prisioneiro" - disse àqueles que o resgataram. Também não gosta muito quando lhe ajudam a tomar banho e tampouco que lhe façam o seu prato de comida, mas chegou à conclusão que é melhor isso aos gritos quando "algumas migalhas" caem no chão. Apesar de tudo sente-se muito contente por ter quem cuide dele.

Todos concordam que ele sempre foi um menino, irradiando uma inocência e tranqüilidade contagiantes.

Tem verdadeira paixão pela música. Aguardava ansioso as serestas de seu pai, chamando os vizinhos para uma roda de cantigas. "Serra da Boa Esperança" sempre foi sua canção favorita! Adorava escutar seu pai cantá-la ao violão. Em sonhos se vê como adolescente, cortejando uma bela moça no portão de casa. Acorda com saudades "não sei de que". Às vezes, sonha estar casado e com três filhos... Sonha que seus filhos estão crescendo e deixando a casa; não gosta muito dessa parte.

Queria poder sair mais de casa, para fazer novas amizades, conhecer pessoas. Nesses últimos tempos só pode contar com a companhia de um coleguinha de brincadeiras que vem visitá-lo nos fins de semana. É o João, um menino gorducho com sete anos e muita disposição para correr, quebrar carrinhos e brincar de esconder.

Uma pena que agora chegara a hora de seu melhor amigo ir embora. Ele se despede com tristeza: - Até mais João.

Ao que o garoto responde: - Tchau vovô.

- Oi Pai, tudo bem? Acena-lhe do carro um homem que ele não consegue se lembrar quem é... Ah! Sim! É o pai do João! 
A velhice se configura como um processo, que possui muitos preconceitos associados ao que representa, os quais se expressam em várias atitudes do cotidiano como a exclusão social do idoso, o apagamento subjetivo, o desinteresse pela história de vida e o medo do contato dos mais novos (especialmente das crianças) com a velhice, devido a sua estreita vinculação com a figura da morte.

Também devemos considerar que esta fase da vida, apesar das possibilidades de bem viver, largamente exploradas pela propaganda consumista, ainda possui uma grande carga de dificuldades e fragilidades, com as quais o sujeito idoso precisa lidar. A marcha inexorável do envelhecimento biológico, muitas vezes vem acompanhada de disfunções fisiológicas, uma progressiva perda das funções executivas e de prejuízos da cognição, especialmente nos casos de demência, como o personagem de nossa trama ficcional.

Se levarmos em conta que o território é um grande agenciador de subjetividades, não podemos nos furtar a olhar detidamente para o fenômeno do envelhecimento e suas particularidades, uma vez que o país nunca teve tantos velhos e a porcentagem dessa faixa etária em relação às demais nunca foi tão expressiva (18\% do total). Portugal é hoje, mais do que nunca, um país de velhos, e um território envelhecido.

No momento em que a velhice ganha novos campos de circulação nas diferentes esferas sociais, tais como o mercado com suas ofertas de produtos e serviços específicos para este público, o estado de direito com leis e estatutos, a ciência através da geriatria e da gerontologia, ainda parece existir uma cegueira por parte da maioria da população, quando o assunto são os velhos e suas singularidades.

Então, vamos abrir essa caixa de pandora e pensar sobre a espinhosa temática do envelhecimento, seus estereótipos, rótulos, suas facetas e dramas vividos no contexto atual de nossa sociedade. Vamos permitir que nossas crianças acostumem o seu olhar à convivência com a velhice, para que eles (os infantes) quando chegarem à idade adulta, não carreguem todos os preconceitos que nós construímos e possam ter uma relação melhor conosco, os futuros velhos, do que nós conseguimos ter no presente imediato. Podemos!?

\section{Referências}

Bosi, E. (1983) Memória e sociedade: lembranças de velhos. São Paulo: Queiroz Editor. 
Debert, G. (2004) A Reinvenção da velhice. São Paulo. EDUSP.

Vilhena, J., Novaes, J.V. \& Rosa C.M. (2014) A sombra de um corpo que se anuncia: corpo, imagem e envelhecimento. Revista Latinoam. Psicopat. Fund., São Paulo, 17(2), 251-264. 


\title{
Anexo 2 - Redes de amigos e vizinhança como fator de proteção social para pessoas idosas isoladas: Estudo piloto em aldeias do concelho da Guarda
}

Artigo aceito para publicação pela Revista Eletrônica Polêmica.

Autores: Ricardo Pocinho, Jorge Castro, Gisela Santos, Carlos Mendes Rosa

Recebido em: 09/01/2015

Aceito em: 14/03/2015

As referências bibliográficas foram mantidas no formato original da revista.

Resumo: O presente estudo pretende compreender a importância da rede de amigos

e vizinhança na perceção de segurança e de proteção por parte das pessoas idosas residentes em contexto rural. A amostra foi constituída por 50 pessoas idosas residentes em meio rural, em diversas aldeias do Concelho da Guarda. De forma a analisar o objeto proposto recorreu-se à Escala Satisfação com o Suporte Social. Os resultados obtidos no presente estudo indicam que os vizinhos e/ou amigos são um bom nível de apoio para as pessoas idosas isoladas. Palavras-chave: Meio rural; Redes de suporte; Vizinhança; Isolamento.

\begin{abstract}
Abstratct: This study aims to understand the importance of the network of friends and neighbors in the security perception and of protection of older persons living in rural context. The sample consisted of 50 elderly people living in rural areas, in several villages of the municipality of Guarda. In order to analyze the proposed object resorted to Scale Satisfaction with Social Support. The results obtained in this study indicate that the neighbors and / or friends are a good level of support for isolated older people. Keywords: Rural Environment; Support networks; neighborhood; Isolation.
\end{abstract}

\section{Introdução}


A visão relativamente ao processo de envelhecimento tem vindo a sofrer profundas alterações ao longo do tempo em diversas áreas da vida humana. Tornou-se, no século XXI, o fenómeno mais relevante e o que mais questões e desafios coloca na sociedade. O envelhecimento projeta relevo e uma prioridade indiscutível, devido ao aumento do número de idosos, e sobretudo, dos muito idosos. Isto mesmo vem no sentido daquilo que (Varues, 1983, citado em Figueiredo, 2014, p.34) afirma: "o processo de envelhecimento tem sobretudo uma dimensão existencial, modificando a relação do homem com o tempo". Encetar conhecimento/ estudo sobre este fenómeno, é de grande importância, uma vez nos últimos CENSOS 2011 (INE, 2011), estão bem patentes os números da população portuguesa, 19\% apresenta uma idade superior a 65 anos (cerca de 2 milhões de idosos), contrariamente aos 15\% do grupo etário dos mais jovens (0-14 anos) e uma esperança média de vida à nascença de 79,2 anos. Tínhamos em 2011, um índice de envelhecimento de 128, ou seja por cada 100 jovens, existem 128 idosos. Estamos perante um aumento exponencial da população idosa, neste sentido o envelhecimento é um dos desafios mais importantes deste século, com tendência para o seu aumento progressivo. De acordo com as projeções realizadas pelo INE, o peso total da população idosa, no total da população, aumentará para os 32,3\% em 2060 (3 043 milhares) (INE, 2011). Esta mesma dinâmica populacional aponta para uma transição demográfica sem precedentes na história, uma vez que, o envelhecimento populacional que se tem vindo a verificar nos últimos anos, acarreta, de forma explícita e concreta, a emergência de uma problematização social, através de uma subjugação dos indivíduos idosos a uma normatização que valoriza a independência e autonomia dos mesmos.

Atualmente verifica-se uma situação complexa onde os atuais problemas da sociedade não residem no envelhecimento nem no aumento da esperança de vida mas sim no facto de a sociedade não se ter adaptado ao "inverno demográfico". São colocados novos desafios à população, no sentido do envelhecimento ser compreendido não como declínio físico, mas sim como uma conquista civilizacional, onde são necessárias sinergias para que este seja bem-sucedido e vivenciado com qualidade. Conscientes desta necessidade, e da importância de investigação no contexto rural, o presente estudo pretende dar um contributo no conhecimento da importância da relação entre os amigos e vizinhança na rede social 
das pessoas idosas que vivem isoladas e num contexto rural, percebendo qual o nível de satisfação que o suporte social pode proporcionar na terceira idade.

O contexto em que uma pessoa se relaciona interfere tanto nas relações sociais como no próprio processo de envelhecimento. De acordo com Lawton (1983 citado em Sequeira, et al., 2002), o meio ambiente em que a pessoa idosa vive é, de facto, um agente relevante na promoção do seu bem-estar, sendo portanto esta relação idoso-ambiente uma relação sensível. Assim, é necessário o conhecimento de como ocorre o processo de envelhecimento em contexto rural, percebendo as suas especificidades, uma vez que o homem não é mais do que um elemento num conjunto em que o ambiente desempenha um papel importante no seu bem-estar e na sua própria saúde. Cada vez mais caminhamos para um desinvestimento desta franja da população, sendo as características rurais e a própria pessoa idosa "carregada" com estereótipos negativos que nada traduz o que deveria ser um envelhecimento ativo.

Kroutse e Coward (1998, citado em Fonseca, Paúl, Martin, \& Amado, 2005) referem os mitos existentes em relação à vivência da "velhice no campo", sendo que se destaca o facto de as pessoas idosas terem um forte apoio de redes familiares e que os mesmos estão sempre disponíveis para lhes prestar os cuidados necessários. Segundo Monteiro (2012) a maioria das pessoas idosas que vivem em meio rural vivem, de facto, longe das famílias estando estas ausentes da vida do idoso. Perante este cenário, percebe-se facilmente que o envelhecimento em meio rural necessita de uma reflexão urgente, uma vez que a tendência é para que este cenário se acentue.

É necessário potenciar e criar condições para que as pessoas idosas permaneçam integradas socialmente e que ao mesmo tempo se possa garantir a sua presença na vida coletiva. Segundo Cabral e colaboradores (2013, p.19) “defender a inclusão social, significa defender a possibilidade de se continuar a participar nos processos de decisão coletiva e para esse fim é importante preservar uma vida ativa durante mais tempo". Os meios rurais podem funcionar como um bom promotor de autonomia na velhice, uma vez que um dos fatores que pode ser considerado de coesão social é o facto de as aldeias constituírem um conjunto de edifícios dissociados especificamente uns dos outros. Esta mesma característica possibilita um maior contacto entre a população e uma maior interajuda perante os diversos 
elementos. Atualmente, o grande problema com o envelhecimento é perceber-se efetivamente qual o lugar da velhice na sociedade (Cabral, et al., 2013).

Quando estamos perante situações em que as pessoas idosas vivem sozinhas, as mesmas têm de recorrer a fontes de suporte social para suprimir diversas expectativas e necessidades. As redes de amigos e vizinhos são as mais comuns em contexto rural, onde existe um ambiente de coesão social e uma forte rede e aproximação entre os diversos elementos. Muitas vezes, é mesmo a única fonte de apoio para as pessoas idosas. Isto reflete-se nas palavras de Domingues (2012, p.179) com a "diminuição da família, os amigos, vizinhos e as restantes pessoas da comunidade, constituem uma rede de suporte social", podendo ainda proporcionar um sentimento de reconhecimento social. Estas mesmas relações não só contribuem para a participação comunitária como ajudam a sustentar o múltiplo processo de envelhecimento.

A rede de amigos e vizinhança tem um número significativo de pessoas, bem como uma aproximação das pessoas idosos, principalmente em função dos novos grupos (e.g. associações, clubes entre outros). Na amizade está intrinsecamente associado o carácter da afetividade, sendo que as relações de vizinhança podem unicamente limitar-se à assistência para o serviço. Fraquinella e Marcon (2011), realçam o facto de as pessoas de idade avançada verem nas amizades uma importância peculiar, pois nesta idade dispõem de muito tempo ocioso, facilitando o contacto com os amigos. Ao contrário das redes familiares, mais de carácter involuntário, as de amigos e vizinhos, assumem-se como uma escolha voluntária, desempenhando um papel pequeno mas fundamental na ajuda à pessoa idosa. Papel este muito associado a questões de relacionamento afetivo. Amigos e vizinhos até podem parecer a mesma coisa, mas existem diferenças entre eles no que respeita às funções e ao próprio processo de relacionamento. Neste sentido, existem tarefas específicas destinadas unicamente aos amigos, nomeadamente as atividades instrumentais: fazer compras; auxilio nas atividades domésticas, entre outras (Andrade, 2002, citado in Domingues, 2012). Este tipo de relacionamento entre amigos só é possível uma vez que os amigos partilham as mesmas dificuldades e limitações, gostos e interesses.

Diversos estudos referem que a amizade contribui para o bem-estar na velhice de várias formas, através do apoio e companheirismo na vida quotidiana, ajuda na manutenção da identidade em mudança e na adaptação à velhice. Quanto 
à relação com os vizinhos, os mesmos "facilitam a obtenção de ajuda informal e reduzem o isolamento social contribuindo assim para o envelhecimento bemsucedido" (Cabral, et al., 2013, p.141). Para Fraquinella e colaboradores (2011) os longos períodos de convivência com os vizinhos são marcados por atividades de ajuda mútua de modo que estes indivíduos se tornam integrantes recíprocos da história de vida das pessoas idosas.

Com o processo de envelhecimento, o diâmetro de espaço de vida das pessoas idosas tende a diminuir. Para estas, a sua vizinhança é o seu principal ou único suporte/retaguarda de vida e segurança, podendo esta refletir-se em diversos efeitos, influenciando ao nível das condições socioeconómicas, integração social da vizinhança, serviços e recursos (Olass, \& Balfour, 2008; citado in Ferreira, 2010). Os relacionamentos entre vizinhos são marcados pela proximidade geográfica e ao mesmo tempo por uma troca habitual de relações que se estendeu ao longo de anos de convivência. É necessário valorizarem-se as redes de amigos e vizinhos, uma vez que o isolamento social provocado por falta de contactos e de reconhecimento social está associado à solidão, à depressão e até a doenças do foro mental (Domingues et al., 2012).

Noutros tempos, as relações de vizinhança e de amizade eram mais vincadas e com um maior número de indivíduos. Atualmente, devido à desertificação das aldeias, este tipo de relações, denota uma tendência a perder-se num futuro próximo.

\section{Metodologia}

\section{Amostra}

A amostragem do presente estudo é de conveniência, uma vez que os casos escolhidos são os que o investigador teve à sua disposição. A amostra foi constituída por 50 pessoas idosas que vivem isoladas e em meio rural, residentes em diversas aldeias do Concelho da Guarda (Pêra do Moço, Aldeia do Bispo, Arrifana e Casal de Cinza).

Os participantes que constituíram a amostra deste estudo cumpriram os seguintes critérios de inclusão: idade igual ou superior a 65 anos; residência em meio rural e numa das aldeias do Concelho da Guarda; isoladas socialmente na maior parte do seu tempo. 


\section{Objetivos}

O presente estudo pretende efetuar uma análise à importância da rede de amigos e vizinhança. De forma mais detalhada, pretende-se perceber se os amigos e os vizinhos são um bom suporte para as pessoas idosas em contexto rural e se existe um sentimento de proteção e segurança relacionado com esta rede social de suporte.

Foram traçadas as seguintes hipóteses, provenientes da observação de fenómenos da realidade, da teoria ou de trabalhos realizados: as pessoas idosas apresentam uma boa satisfação com o suporte social (H1); as pessoas idosas não apresentam uma boa satisfação com o suporte social (H0); os amigos e os vizinhos são um bom suporte social para as pessoas idosas e os mesmos prestam o auxílio e a proteção necessária $(\mathrm{H} 1)$; os amigos e os vizinhos não são um bom suporte social para as pessoas idosas (H0); as pessoas idosas residentes em meio rural (isolados), apresentam uma maior satisfação em relação aos amigos, do que em relação à família (H1); as pessoas idosas residentes em meio rural (isoladas), apresentam uma menor satisfação em relação aos amigos, do que em relação à família (H0).

\section{Instrumentos}

Elaborou-se um protocolo de investigação constituído por um questionário sociodemográfico e pela Escala de Satisfação com o Suporte Social (ESSS; PaisRibeiro, 1999).

O Questionário Sociodemográfico foi elaborado especificamente para esta investigação e contém questões relacionadas com o género, idade, estado civil, nível de escolaridade. O mesmo contém ainda questões específicas direcionadas especialmente para o presente estudo: auxílio por parte dos vizinhos e/ou amigos, proteção e necessidades em termos de urgência.

A Escala de Satisfação com o Suporte Social, desenvolvida por Pais-Ribeiro (1999), Trata-se de uma escala multidimensional, de autopreenchimento, constituída por 15 itens, de autopreenchimento, de resposta tipo Likert. Tem como objetivo principal verificar/ avaliar quatro fatores: "Satisfação com os Amigos" (SA), que mede a satisfação com as amizades/ amigos dos indivíduos; "Intimidade" (IN), que mede a perceção da existência de suporte social íntimo; Satisfação com a Família" (SF), que mede a satisfação com o suporte social familiar; "Atividades 
Sociais" (AS), que mede a satisfação com as atividades sociais que os indivíduos realizam. A pontuação para a escala total consiste no somatório de todos os itens e pode variar entre 15 e 75 e à pontuação mais alta corresponde uma perceção de maior suporte social. Não há pontos de corte que possam ser considerados como deficitários. (Ribeiro, 2011).

\section{Procedimentos}

Aquando da recolha dos dados todos os participantes foram informados acerca dos objetivos do estudo, a forma de administração do questionário e a confidencialidade dos dados. O tempo médio de administração foi de 10 minutos.

O tratamento dos dados efetuou-se através do programa estatístico SPSS 20.0 (Statistical Package for Social Sciences). Foram realizadas análises estatísticas descritivas relativamente à componente sociodemográfica da amostra na determinação das frequências absolutas e relativas; medidas de tendência central média, mediana, moda, desvio padrão, como medida de dispersão. De seguida, analisou-se a ESSS Relativamente às pontuações totais e pontuações das variáveis latentes.

\section{Resultados}

\section{Análise descritiva}

A amostra é constituída por 50 indivíduos de ambos os géneros, com idades compreendidas entre os 67 anos e os 100 anos, $(M=82.5)$ (c.f. Tabela 1) A amostra é maioritariamente feminina, como se pode observar através da seguinte tabela (c.f. Tabela 2).

Tabela 1. Caraterização da amostra em relação à idade

\begin{tabular}{ccc}
\hline & M & DP \\
\hline Homens & 81 & 21 \\
Mulheres & 83 & 7.1 \\
Total & 82.5 & 13.2 \\
\hline
\end{tabular}


Tabela 2. Caraterização da amostra em função do género, estado civil, nível de escolaridade e agregado familiar

\begin{tabular}{lcc}
\hline \multicolumn{1}{c}{ Variáveis } & N & \% \\
\hline Género & 16 & $32 \%$ \\
Masculino & 34 & $68 \%$ \\
Feminino & & \\
Estado Civil & 5 & $10 \%$ \\
Solteira(o) & 12 & $24 \%$ \\
Casada(o) & 1 & $2 \%$ \\
Separada(o) & 31 & $62 \%$ \\
Viúva(o) & 1 & $2 \%$ \\
União de facto & & \\
Nível de Escolaridade & 27 & $54 \%$ \\
Sem escolaridade & 16 & $32 \%$ \\
Até 4 anos de escolaridade & 7 & $53 \%$ \\
Outro & 28 & \\
Reside Sozinho & & \\
Sim & 28 & \\
Não & & \\
\hline
\end{tabular}

Pode-se constatar que se trata de uma amostra com indivíduos maioritariamente do género feminino (68\%), viúvos (62\%) e que os mesmos não têm escolaridade (54\%). Do total, 55\% das pessoas idosas não residirem sozinhas. De referir que estes participantes até podem não residir sozinhos, mas não invalida que não estejam sozinhos na maior parte do tempo.

O questionário de dados sociodemográficos foi, ainda, constituído com questões específicas, formuladas de acordo com o contexto e o objetivo de toda a investigação, Servindo também para se tirar conclusões mais precisas sobre o suporte social de amigos e vizinhos. (c.f. Tabela 3). 
Tabela 3. Resultados relativos às questões específicas dos questionários da amostra.

\begin{tabular}{lccc}
\hline & & N & \% \\
\hline $\begin{array}{l}\text { Considera que os seus amigos e/ ou } \\
\text { vizinhos lhe prestam o auxílio }\end{array}$ & Sim & 48 & $96 \%$ \\
$\begin{array}{l}\text { necessário? } \\
\text { Sente-se protegido pelos seus }\end{array}$ & Não & 2 & $4 \%$ \\
$\begin{array}{l}\text { amigos/ vizinhos? } \\
\text { Em caso de necessitar de alguma }\end{array}$ & Não & 49 & $98 \%$ \\
coisa urgente a quem recorre & Amigos/ & 25 & $2 \%$ \\
primeiro? & Vizinhos & & $50 \%$ \\
\hline
\end{tabular}

Constata-se que as pessoas idosas isoladas consideram que os amigos e/ou vizinhos lhe prestam o apoio necessário (96\%) e que estes se sentem protegidos pelos amigos/ vizinhos (98\%). Um dado curioso observado na tabela anterior, refere-se ao apoio tanto dos amigos como dos familiares, quando um idoso necessita de alguma coisa urgente, sendo que com os dados apresentados não se conseguem tirar conclusões uma vez que metade da amostra (50\%) referem recorrer aos amigos/vizinhos e a outra metade aos familiares.

\section{Escala Satisfação com o Suporte Social (ESSS)}

A partir dos dados obtidos (c.f. Tabela 4), pode-se verificar que, em média, os participantes apresentam uma pontuação total da ESSS de 55,54 pontos $(D P=8.3)$, sendo que a população masculina obteve uma pontuação total de 57.5 $(D P=8.4)$ e a população feminina $54.6(D P=8.3)$. Este resultado indica que a perceção da ESSS na pontuação total, no caso das redes de amigos e vizinhos, são um bom nível de apoio para as pessoas idosas isoladas, uma vez que a amplitude da pontuação total da ESSS, varia entre 15 e 75 . Uma pontuação mais alta corresponde a uma perceção de maior suporte social. 
Tabela 4. Médias e desvios-padrão da pontuação total da ESSS em função do género

\begin{tabular}{cccc}
\hline & M & DP & A \\
\hline Homens & 57.5 & 8.4 & $42-71$ \\
Mulheres & 54.6 & 8.3 & $34-68$ \\
Total & 55.54 & 8.3 & $34-71$ \\
\hline
\end{tabular}

Pode-se, ainda, verificar que a pontuação mínima obtida no conjunto da amostra foi de 34 pontos, e a máxima de 71. A amplitude mínima para a população masculina foi de 42 pontos e a máxima de 71 pontos. Relativamente ao género feminino, observamos uma pontuação mínima de 34 pontos e uma máxima de 68 pontos.

Para além da pontuação total da ESSS, esta é constituída por quatro fatores (subescalas), sendo a pontuação total de cada uma apresentada de seguida após regra de três simples ${ }^{3}$.

Tabela 5. Pontuação totais obtidas nas 4 dimensões da ESSS

\begin{tabular}{lc}
\hline \multicolumn{1}{c}{ Fatores/ Subescalas } & Pontuações obtidas (0 a 100) \\
\hline Satisfação com os amigos (SA) & 79,44 \\
Intimidade (IN) & 74,20 \\
Satisfação com a família (SF) & 81,61 \\
Atividades Sociais (AS) & 57,50 \\
\hline
\end{tabular}

${ }^{3}$ Dado que, o número de itens de cada dimensão é diferente, as pontuações mínimas e máximas por dimensão também o são, como já referido nos métodos. Recorreu-se à regra de três simples para se converter as pontuações obtidas entre 0 e 100 , sendo que $0=$ pontuação mais baixa possível e $100=$ pontuação mais elevada possível. 
Com os resultados obtidos, verifica-se que todos os fatores apresentam valores acima da média (50 pontos), sendo que a subescala "Atividades Sociais" (AS) é o domínio que apresenta uma pontuação mais baixa comparativamente com os restantes fatores (57,50). Em contrapartida, os fatores que apresentam uma pontuação mais elevada são a "Satisfação com a Família" $(81,61)$ e "Satisfação com os Amigos" (SA) $(79,44)$, não existindo diferença significativa, entre estas duas variáveis. Outro dado apresentado é o fator "Intimidade" (IN) apresentando uma pontuação de $(74,20)$, verificando-se que no que concerne ao suporte social, a população idosa do estudo indica que, para além das relações familiares e de amizade, o suporte íntimo é o que lhes proporciona maior satisfação.

\section{Discussão}

O presente estudo pretendeu perceber efetivamente se os amigos/vizinhos são um bom suporte social para as pessoas idosas que vivem isoladas. Neste sentido, e de acordo com os resultados obtidos através da ESSS, verificou-se que os vizinhos e/ou amigos são um bom nível de apoio para as pessoas idosas isoladas, confirmando-se a hipótese formulada. Este resultado vai ao encontro dos estudos desenvolvidos por Sequeira e Silva, (2002) que tinham como principais objetivos perceber quais eram os fatores inerentes à satisfação num grupo de residentes em meio rural. O mesmo estudo foi constituído por 50 participantes idosos, concluindo que em contexto de meio rural existem níveis de bem-estar apontando-se para uma adequada relação idoso/meio.

Relativamente ao sentimento de segurança e de proteção que as pessoas idosas possam sentir, esta hipótese é confirmada através das pontuações obtidas nas questões específicas do questionário elaborado para a presente investigação. Através da análise de resultados verificou-se que $96 \%$ da amostra considera que os amigos prestam o auxílio necessário. Para além da presente investigação, estudos diversos ajudam a confirmar este resultado. No estudo desenvolvido por Cabral e colaboradores (2013), o mesmo possibilitou avaliar as relações de vizinhança, tendo em consideração três aspetos: identificação dos vizinhos, a frequência de conversação e o tempo de permanência. Através dos resultados obtidos pode-se verificar que os mesmos permitem deduzir um elevado conhecimento, ou pelo menos reconhecimento dos vizinhos e um padrão bastante regular de interações sociais. Relativamente à proteção das pessoas idosas isoladas por parte dos amigos 
e/ou vizinhos, verificou-se que $98 \%$ da amostra refere sentir-se protegido. Muitas das vezes o que se verifica é que a proteção em meio rural está muito associada às relações de confiança que vão sendo estabelecidas pelos diversos elementos. Este mesmo resultado e conclusão estão de acordo com o estudo desenvolvido por Franquinello e Marcon (2011), que tinha como principal objetivo compreender a atuação da rede representada pelos amigos e vizinhos de adultos idosos hipertensos. As conclusões do estudo reportam para o facto de o tempo de moradia interferir no vínculo com os vizinhos.

Além dos resultados apresentados indicarem que as redes de amigos e vizinhança são um bom suporte social e de proteção para pessoas idosas isoladas/ meio rural, existe por parte destes uma distinção entre o que para eles são amigos e vizinhos. Estas mesmas conclusões só foram possíveis através do contacto pessoal com pessoas idosas isoladas, onde estes afirmam muitas das vezes que até podem ter vizinhos, mas que estes não são amigos. Esta mesma conclusão poderá estar associada à confiança entre as pessoas idosas em meio isolado.

No que diz respeito à hipótese das pessoas idosas residentes em meio rural apresentarem uma menor satisfação relativamente aos seus amigos comparativamente à família, os resultados obtidos no estudo apontam para a inexistência de uma diferença significativa. Assim, não se conseguiu comprovar que as pessoas idosas apresentam uma maior satisfação em relação à família do que em relação aos amigos. Por outro lado, os dados apresentados podem querer dizer que a família e os amigos são o principal suporte social para as pessoas idosas isoladas e que os mesmos se complementam, ou interligam. Através do questionário sociodemográfico, pode-se verificar esta mesma semelhança, uma vez que $50 \%$ da amostra refere recorrer aos amigos e/ou vizinhos em caso de necessidade urgentes e os outros $50 \%$ recorrem aos familiares. Isto vai ao encontro do estudo desenvolvido por Leite, Battista, Berlezi e Schever (2008) tendo como principal objetivo analisar o suporte familiar e social de 338 pessoas idosas, com uma faixa etária dos 60 aos 65 anos.

As conclusões do estudo indicam que $87 \%$ das pessoas idosas possuem uma rede familiar e social que lhes fornecem suporte de natureza emocional, material, afetiva e informativa. No caso de a família dos idosos isolados e residentes em meio rural, não prestarem o apoio necessário, são os amigos e/ou vizinhos que assumem este papel, sendo o principal meio de ajuda. Isto mesmo pode-se verificar, por 
exemplo no caso de as pessoas idosas terem familiares no estrangeiro, ou então na ausência por determinados períodos de tempo (ex. trabalho na cidade). No estudo desenvolvido por Fonseca, Paúl, Martin e Amado (2005) onde numa amostra de 117 indivíduos, com uma média de idades de 74,5, concluiu-se que as pessoas idosas rurais envelhecem longe dos filhos e netos.

\section{Conclusão}

No início desta investigação houve uma questão que esteve na base de todo o trabalho, a de saber até que ponto a rede de amigos e vizinhança, contribuía para a satisfação e ao mesmo tempo para a proteção social de pessoas idosas residentes isoladas e/ou meio rural.

De todos os dados demográficos pode-se concluir que o perfil dos participantes no estudo caracteriza-se por serem, na sua maioria, do género feminino, com idade média de 82 anos, viúvos e que os mesmos se sentem protegidos pelos amigos e/ou vizinhos, prestando-lhes o auxílio necessário.

Relativamente à ESSS, verifica-se que os vizinhos e/ou amigos são um bom nível de apoio para as pessoas idosas isoladas $(M=55,54)$. A variável Satisfação com os Amigos (SA) obtém uma pontuação inferior, comparativamente com a variável Satisfação com a Família (SF), 79,44 e 81,61 pontos, respetivamente.

Partindo da questão colocada, conclui-se que não há uma diferença significativa que possa comprovar que as pessoas idosas apresentam uma maior satisfação em relação à família do que em relação aos amigos, ou seja, ambos se complementam no cuidado à pessoa idosa.

De acordo com os factos, o presente trabalho apresenta algumas limitações, que devem ser consideradas em investigações futuras, nomeadamente: o tamanho da amostra deveria ser maior de forma a ser mais representativa da população idosa do concelho abrangido, tirando-se conclusões mais profundas relativamente às hipóteses formuladas.

Atualmente, 377 pessoas idosas vivem isoladas e sozinhas no Concelho da Guarda, neste sentido e como o fim de um trabalho é sempre uma oportunidade da realização de um novo, fica a questão: Serão as redes de amigos e vizinhos nas pessoas idosas mais eficazes nas aldeias do que nas Cidades? 


\section{Bibliografia}

Cabral, M. (Org.), Ferreira, P., Silva, P., Jerónimo, P., \& Marques, T. (2013). Processos de envelhecimento em Portugal, uso do tempo, redes socais e condições de vida. Lisboa: Fundação Francisco Manuel dos Santos

Domingues, M. (2012). Mapa mínimo de relações do idoso: uma ferramenta para avaliar rede de suporte social. In F. Pereira (Org.), Teoria e prática da gerontologia, um guia para cuidadores de idosos. (pp.175-188). Viseu: Psicosoma.

Faquinello, P., \& Marcon, S. (2011). Amigos e vizinhos: uma rede social ativa para adultos e idosos hipertensos. Rev. Esc. Enferm. USP, 45(6), 345-52.

Fonseca, A., Paúl, C., Martin, I., \& Amado, J. (2005). Condição psicossocial de idosos rurais numa aldeia do interior de portugal. In C. Paúl, \& A. Fonseca (Cord.) Envelhecer em portugal, psicologia, saúde e prestação de cuidados (pp. $97-$ 108). Lisboa: Climepsi Editores.

Leite, M., Battist, I., Berlezi, E., \& Scheuer, A. (2008).Idosos residents em meio urbano e sua rede de suporte familiar e social. Texto \& ContextoEnfermagem, 17(2), 250-257.

Monteiro, C. (2012). Idosos residentes em meio rural: satisfação com o suporte social. Tese de mestrado não publicada apresentada ao Departamento de Economia, Gestão e Ciências Sociais, Universidade Católica Portuguesa.

Sequeira, A., \& Silva, M. (2002). O bem-estar da pessoa idosa em meio rural. Análise Psicológica, 20(3), 505-516.

Ribeiro, J. (1999). Escala de satisfação com o suporte social (ESSS). Análise Psicológica, 17(3), 547-558. 